\title{
Hayas cultivadas memorables de Galicia: apuntes históricos, culturales y botánicos
}

Recibido: 2 Maio 2009 / Aceptado: 30 Xuño 2009

(C) IBADER- Universidade de Santiago de Compostela 2009

\begin{abstract}
Resumen El trabajo ofrece una reseña cronológica del uso del haya europea (Fagus sylvatica L.) como especie ornamental en Galicia y hace una caracterización mediante 95 registros de árboles memorables, localizados en 45 escenarios de cultivo (pazos, castillos, bienes eclesiásticos, balnearios, fincas particulares, viveros, ámbitos escolares, jardines municipales urbanos públicos y espacios naturales), distribuidos por las provincias de A Coruña, Lugo, Ourense y Pontevedra. La condición que se le otorga a estos registros se justifica por la concurrencia de un conjunto méritos propios o intrínsecos, ligados a valores fisionómicos corporales individuales (morfología, biometría, fitosanidad), y de atributos ajenos o extrínsecos, procedentes de parámetros externos diversos (históricos, culturales, artísticos, literarios, científicos, geográficos, paisajísticos, ecológicos, tradicionales), de la información oral, así como del bagaje documental y bibliográfico. Méritos y atributos necesarios para su inclusión y puesta en valor en el catálogo patrimonial de fagus memorables del Fogar de Breogán.
\end{abstract}

Palabras clave Haya · Morfología · Biometría · Fitosanidad. Fitogeografía · Historia · Cultura · Flora memorable

\begin{abstract}
The work offers a chronological outline of the use of the European beech (Fagus sylvatica L.) as ornamental species in Galicia and it draws a description through 95 entries of memorable trees located in 45 growing scenes (country houses, castles, church properties, spas, private properties, nurseries, educational institutions, municipal urban public gardens and green spaces), distributed throughout the Galician provincies: A Coruña, Lugo,
\end{abstract}

Carlos Rodríguez Dacal

IES Antonio Fraguas Fraguas

Rúa Londres, 10

15707 Santiago de Compostela

e-mail: crdacal@edu.xunta.es
Ourense and Pontevedra). The level given to these entries is justified by the combination of a group of intrinsic own qualities linked to fisonomic physical individual features (morphology, biometry, phytosanitary), also by the combination of alien extrinsic qualities from different external parameters (historical, cultural, artistic, literary, scientific, geographical, ecological, traditional and those related to landscape), from information transmitted orally from documentary and bibliographical knowledge. All of them are necessary qualities to be included and valued within the patrimonial catalog of memorable fagus from Fogar de Breogán.

Key words Beech - Morphology - Biometry - Phytosanity . Phytogeography $\cdot$ History $\cdot$ Culture $\cdot$ Memorable flora

\section{Reseña histórica}

Deben su nombre, las fagáceas, a los vocablos "phēgós" (griego) y "fagus" (latino), en alusión a los frutos comestibles que, en la especie que nos ocupa -el haya europea (Fagus sylvatica L.)-, son oleaginosos y muy nutritivos, de mucho aprecio por parte de algunos animales salvajes $y$ domésticos, tanto mamíferos como aves, y que, desde la antigüedad, formaron parte de la dieta alimenticia humana. Familia botánica, las fagáceas, encabezada por el género Fagus -engloba una decena de especies caducifolias que habitan en regiones templadas del Hemisferio Norte-, a la que pertenecen otros géneros tan genuinos y expresivos en nuestra geografía como Quercus y Castanea. De la decena, Galicia sólo cuenta con una especie: el haya europea, que aparece espontáneamente como bosque autóctono montano, cultivándose también en espacios ajardinados y otros ámbitos naturales como árbol de interés ornamental. Especie social, noble, de sombra, que presenta el temperamento más delicado entre las frondosas principales del país.

Mirando la hoja de servicios del haya europea, la utilidad y la función prestadas desde tiempos inmemoriales la convierten en una especie dual, de interés material y 
espiritual. La producción material se centra en la explotación de su madera y de su leña, así como en el consumo de sus frutos. La madera reúne excelentes cualidades y goza de mucho aprecio industrial. Su leña encierra gran poder calorífico, que le ha otorgado un papel combustible en muchos países. El valor nutritivo de sus frutos ha sido aprovechado, desde tiempos prehistóricos, tanto por el hombre como por los animales.

Como árbol de cultivo, con miras ornamentales, se halla en alamedas, jardines, parques, plazas y paseos, con una apreciable nómina de ejemplares sobresalientes, correspondientes mayormente al tipo silvestre y al cultivar 'Purpurea'. No sorprende a nadie su amplio grado de aceptación y uso jardinístico, ni tampoco el trato de favor deparado por el público, bien ganados por su porte, caracterizado por su considerable talla y elegante hechura; por la arquitectura corporal, determinada por la significada volumetría copal y la preponderancia troncal; por el follaje, muy abundante y tupido, con hojas de mediano tamaño, de bordes enteros y ondulados, con pelos sedosos, formando una capa impenetrable a los rayos solares productora de fresca sombra en la época que más se necesita; y por sus frutos, llamados hayucos, estructura más reconocible por su singularidad, compuestos por nueces, de sección triangular, encerradas en una cubierta o cúpula erizada no punzante que se abre en cuatro valvas en su madurez.

Las hojas aportan, como valor añadido, de gran impacto visual y mucho aprecio jardinero-paisajístico, el muestrario de colores que ofrecen sus cultivares y los llamativos contrastes cromáticos otoñales, por viraje, antes de la caída, permaneciendo en este estado largo tiempo sobre las ramas. El tomo 6 de Flora. Enciclopedia Salvat de la Jardinería (Salvat Editores, 1978) dedica a este fenómeno un párrafo explicativo que se inserta por su innegable interés: "El color del follaje constituye uno de los elementos básicos para determinar el carácter ornamental de muchas plantas. En ciertas especies, este carácter resulta acrecentado al finalizar la estación cálida, pues entonces se producen interesantes variaciones de color, como ocurre en el haya. En realidad, este fenómeno está relacionado con el descenso de actividad vegetativa, por el cual disminuye el contenido de clorofila del ejemplar en cuestión. Entonces llega un momento en que en las hojas predominan otros pigmentos, como la carotina y la xantofila, que motivan el viraje hacia un color anaranjado o amarillo, respectivamente".

De paseo por la historia, haciendo una visión retrospectiva somera acerca del concurso y el empleo del haya como elemento florístico ornamental en los lares gallegos, hay que decir que los dos modelos más practicados en el quehacer jardinístico, desde sus orígenes hasta la actualidad, han sido el bosque sagrado y el patio. Entre las civilizaciones antiguas, el bosque sagrado era un espacio de grandes dimensiones, de carácter paisajista, con las masas arboladas como formaciones protagonistas, acompañadas por templos y altares, para culto y veneración de dioses y divinidades mitológicas, donde los usuarios llevaban a cabo sus celebraciones rituales, caza, pesca y otra clase de actividades lúdico-recreativas. En Galicia, tenemos constancia de esta clase de espacios a través de los lucus, bosques sagrados donde los druidas realizaban sus prácticas, que pueden ser considerados como jardines primitivos, entendiendo como tal esta manifestación del paisaje natural. Los lucus, mayormente asociados a bosques de quercus en nuestra tierra, no se descarta que, en el área de distribución natural del haya, estuvieran representados por poblaciones de este bosque montano, constituyendo, de ser cierta esta consideración, la primera manifestación o testimonio del uso de la especie desde una óptica ornamental.

En el intento de establecer el punto de partida de la utilización del haya en el país como especie de ornato, ligada a la práctica del arte de la jardinería, el periodo temporal que abarca la cultura castrexa y la romanización es un referente obligado. Mal que nos pese, hasta el momento, aunque en otros ámbitos geográficos próximos existe constancia documental del quehacer jardinístico, en el Fogar de Breogán no se han encontrado testimonios al respecto. Por lo que nada sabemos del significado plástico y espiritual del mundo vegetal para nuestros ancestros, del que forma parte el haya, ni podemos hacer consideraciones acerca de su valor ornamental y lúdico-recreativo.

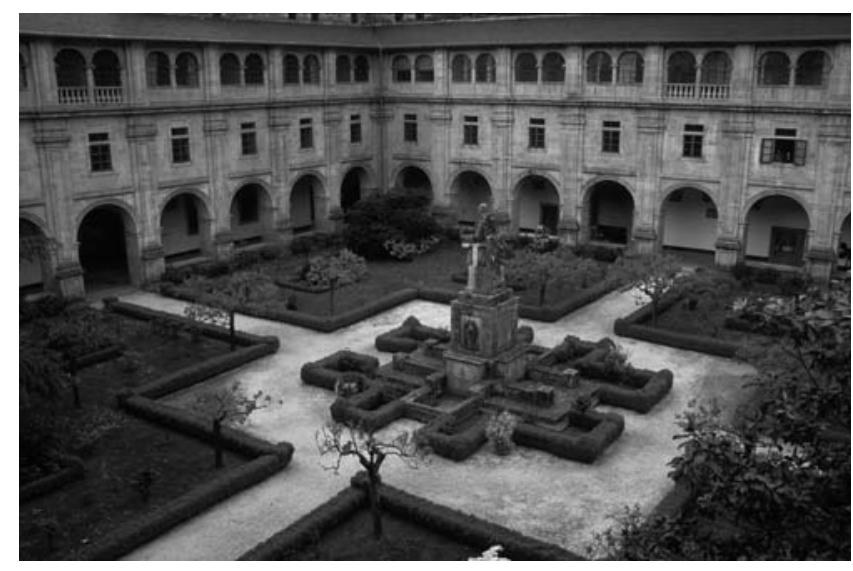

Claustro Grande del Monasterio de Samos. Los hortus conclusus no aconsejan la plantación de hayas

A decir verdad -aunque esta especie arbórea está entre nosotros desde tiempos remotos, como confirman los datos proporcionados por la palinología-, no existe evidencia de ninguna clase, en estas centurias, que avale nuestro empeño de poner fecha al comienzo del curso existencial del haya como árbol ornamental en Galicia. Ni ornamental ni material, ya que los datos palinológicos y los restos botánicos hallados en yacimientos arqueológicos no aportan pruebas ni noticias que certifiquen la presencia de esta especie autóctona y su uso por parte de los pobladores castrexos. Aunque el arte de la creación y diseño de jardines se viene ejercitando de manera habitual y regular por parte de las civilizaciones y culturas antiguas (Egipto, Mesopotamia, Persia, Grecia, Roma), por sorprendente que parezca, la romanización no ha dejado, a día de hoy, ninguna huella o rastro que certifique la práctica jardinística y de plantaciones vegetales de ornato en nuestra tierra. 
La Caída del Imperio Romano pone fin a la Edad Antigua y a las manifestaciones del arte de la jardinería desarrolladas desde la antigüedad, entrando de lleno en la Edad Media, largo periodo de siglos, que dura mil años, donde las guerras y los desajustes sociales dejan poco margen para el quehacer artístico, que pasa por un tiempo de estancamiento y desaparece del ámbito público para quedar restringido y reservado a los estamentos sociales privilegiados (Iglesia y Nobleza), estando vinculado sobre todo al mundo eclesiástico (monasterios, conventos, catedrales, etc.). De la mano de los monjes, preferentemente, se va a desarrollar un modelo conocido como hortus conclusus, que responde a dos tipologías bien diferenciadas según el escenario y el grado de elaboración: el jardín claustral, en los patios de los edificios residenciales, de mayor categoría y entidad; y el jardín de plantas medicinales, en las huertas, al servicio de las boticas.

Por razones obvias, los hortus conclusus no son lugares propicios para la plantación de hayas. En el caso de los jardines claustrales, las limitaciones de espacio no permiten ni aconsejan la plantación de árboles que desarrollan grandes portes. En lo tocante a los jardines de plantas medicinales, hay que decir que la vertiente saludable y curativa no es el fuerte de esta especie que, históricamente, tiene en la madera y los frutos los principales recursos materiales apetecidos y aprovechados por el hombre. La consulta del libro Boticas Monacales y Medicina Naturista de Galicia (Sa Bravo, 1983), obra señalada de su género, es reveladora e indicativa para la constatación de la ausencia del haya como árbol medicinal, no figurando en ninguno de los catálogos monacales en la composición de los medicamentos preparados en las boticas, a partir de sus distintas estructuras vegetativas, florales y frutales.

La no disponibilidad de datos y noticias al respecto, por falta de estudios monográficos sobre la jardinería monacal gallega, impide hacer consideraciones y sacar conclusiones serias y rigurosas, de tal manera que la información que aportan las consultas realizadas en archivos y las publicaciones disponibles sobre la existencia y la utilidad del haya en el Medievo sólo nos proporciona citas concretas sobre su presencia, que nada tienen que ver con su empleo como árbol ornamental ligado a tal clase de jardines. Esta es la causa que nos mueve a ser prudentes y a no descartar que en estos establecimientos y otros bienes de parecida entidad constructiva y dimensionalidad territorial (castillos, casas fuertes, hospitales, iglesarios), sobre todo en los emplazados en su área de distribución natural, el haya pudo hacer acto de aparición en cualquiera de los dominios (jardín, huerta, bosque) de tales propiedades.

La Abadía de Samos -con su monasterio, sus prioratos, sus iglesias y sus tierras- constituye un magnífico ejemplo para ilustrar lo dicho. Nada sabemos con certeza de la presencia de tal clase de árboles dentro de la vasta jurisdicción monacal, pero creemos que en bosques, huertas y jardines samonenses, silvestres o cultivadas, prestaron beneficios materiales y espirituales a la comunidad. A día de hoy, la pertenencia del Pazo de Lusío/Samos al Monasterio de San Julián nos proporciona un argumento más, tomando en consideración la masa de hayas que vegeta en el bosque pacego. ¿Cómo habrán llegado hasta el lugar que ocupan? ¿Son autóctonas o introducidas? La proximidad a los escenarios boscosos naturales deja abierta la posibilidad de un estado silvestre, pero la práctica jardinística pacega propicia la vía introductoria.

Ante esta situación, quisiera llamar la atención de un nuevo elemento: el escudo señorial, de piedra marmórea, bien conservado, empotrado en el edificio pacego ruinoso, que entra en escena por la presencia de un árbol que ocupa la mitad del cuarto cuartel. ¿A qué especie corresponde? Dejando volar nuestra imaginación, podría tratarse de un haya, ¿porqué no? A sabiendas de que no es más que una representación artística, en apoyo de nuestra suposición están el formato arquitectónico y el carácter liso de la corteza de tronco y ramas. No sé si puede más el corazón que la cabeza, pero lo cierto es que esta posibilidad no se debe descartar, como tampoco que sea un carballo u otra especie. Un apunte más: la aparición del árbol en el escudo de armas, como cualquiera de los otros elementos esculpidos, es prueba inequívoca de su raigambre y protagonismo para el linaje familiar del pazo, fundado a mediados del siglo XVI.

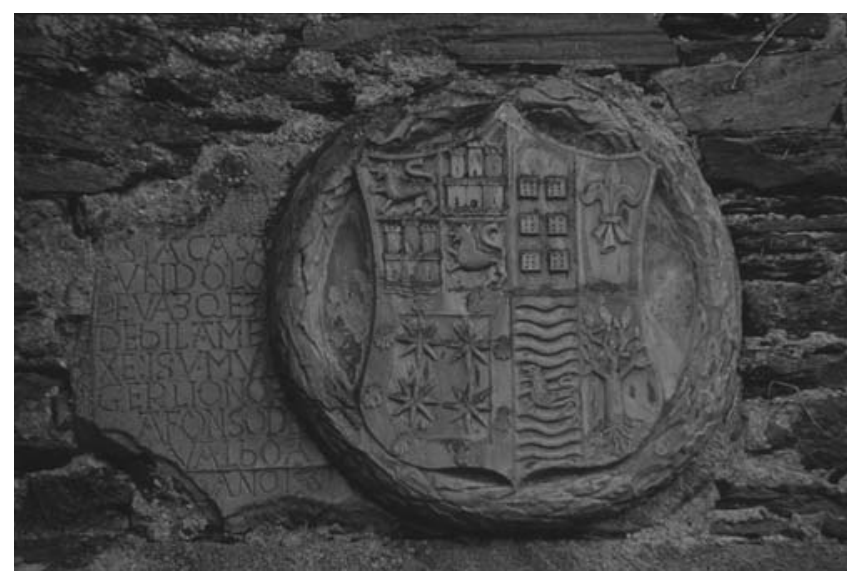

En el cuarto cuartel del escudo de armas del Pazo de Lusío/Samos, figura un árbol, ¿será un haya?

Páez de la Cadena (1982), en la Historia de los Estilos de Jardinería, al referirse a los jardines medievales y a los jardines hispanoárabes, incorpora extensos inventarios florísticos, con especies arbóreas, arbustivas y herbáceas florales. El haya no figura en ninguno de ellos. Aunque esta ausencia no es sinónimo de falta de empleo y presencia en tal clase de establecimientos jardinísticos, es un apunte a tomar en consideración, cuando menos, en apoyo de la hipótesis que supone que, durante tan dilatado periodo de siglos, no era un árbol popular y de uso habitual.

Sin nexo de unión con el mundo de la jardinería, por razones cronológicas y en plan anecdótico, no puedo ni quiero sustraerme a hacer un comentario acerca del significado nomenclatural de una de las puertas más señeras de la muralla de la Ciudad Apostólica Compostelana: la Puerta Fagera, que conecta con Padrón y el Camino Portugués. Lo hago como apoyo a una de las 
explicaciones terminológicas dadas por López Ferreiro, que la relaciona con el haya. Moralejo et al. (1998), en Liber Sancti Jacobi "Codex Calixtinus", hacen la siguiente consideración: "La 5. ${ }^{a}$ ( $p$. de Falgueriis, $4 .^{\text {a }}$ en la versión gallega y "de Fageiras») es hoy la más conocida por ser la salida hacia la Alameda y la Herradura; pero su nombre latino supone una forma falgueria, base del provenzal falgueira y catalán falguera "helecho» (v. Mlle. Vielliard, pag. 85, n. 5), que daría en gallego lo mismo que en provenzal y no fageira o su castellanización fagera; parece, pues, tratarse de una falsa latinización, ya que L. Ferreiro $(\mathrm{V}, 164, \mathrm{n} .3)$ da también la forma de faiariis, quizá de fagus "haya»".

La Edad Moderna se caracteriza por la preponderancia de la jardinería privada, controlada por el sector eclesiástico, enriqueciéndose por aparición de nuevas tipologías, representadas por los jardines palaciegos urbanos y los jardines pacegos rurales. El modelo practicado sigue ajustándose primordialmente al hortus conclusus aunque da cabida, en la medida de sus posibilidades, a las nuevas creaciones renacentistas. A decir verdad, por las razones expresadas en la época medieval, lo cierto es que hay poca información para poder hacer afirmaciones sobre la utilización del haya como especie ornamental. En resumidas cuentas, no encontramos fuentes documentales ni referencias bibliográficas que citen el haya por su nombre. En apoyo a lo dicho, no figura en el Viaje de Ambrosio de Morales (Florez, 1765), realizado en el siglo $\mathrm{XVI}$ y publicado dos centurias después, ni en la Descripción del Reyno de Galicia (Licenciado Molina, 1550), ni tampoco en la Primera Parte de el Árbol Chronologico de la Santa Provincia de Santiago (Jacobo de Castro, 1722).

Mención especial, hacia finales de este periodo histórico, para el Padre Sarmiento, cuyos escritos ponen de manifiesto su afición, sus conocimientos y su contribución botánica. Gracias a este monje benedictino, sabio e ilustrado, que vivió en el siglo XVIII, disponemos de abundantes citas sobre la flora ornamental del país. Aunque la consulta de su obra, a través de los viajes realizados a Galicia, no ha producido resultados positivos en lo tocante a la cita del haya como especie de adorno, ligada a espacios ajardinados, plazas o viales urbanos.

A falta de noticias en Galicia, a lo largo del Medievo y la Edad Moderna, seleccionamos, por su valor cultural, un testimonio muy ilustrativo, procedente del continente europeo y vinculado al mundo monacal, en concreto a una propiedad francesa montana inmersa entre hayedos, cuyos árboles, afectados por un extraño fenómeno natural, nacen de semillas y son reproducidos por acodo. Manifestación patente del papel dual prestado por dicha especie, originalmente material, para provecho de su madera y de su leña; y posteriormente espiritual, para conservación y multiplicación de este arbolado de porte singular, con miras de garantizar su contemplación y disfrute ornamental.

Aunque este fenómeno adquiere el máximo realce y celebridad en el bosque montañoso sagrado de Verzy, donde se contabilizan en torno a un millar de ejemplares sito a pocos km de Reims, al nordeste de Francia; bien de la Abadía de San Basles desde el siglo XII hasta la
Revolución Francesa-, lo cierto es que éste y otros hayedos europeos son protagonistas de tal hecho fenomenal que sorprende a propios y extraños, consistente en el carácter retorcido que muestran sus troncos y sus ramas, responsables de portes sin parangón, que le han valido el nombre de "hayas sacacorchos". Cualidad que hacen figurar a las hayas francesas en el libro Árboles Excepcionales del Mundo, cuyo autor (Thomas Pakenham, 2004) ofrece una explicación botánica convincente:

"Al decir de los expertos, se trata en realidad de una mutación genética del haya común (Fagus sylvatica). Unas cuantas nacieron a partir de semillas y no recuperaron la apariencia normal, aunque la inmensa mayoría se desarrollaron por acodo. Los expertos nos aseguraron que lo de las faux (hayas) es un fenómeno totalmente natural y que, por tanto, nadie tendría que responsabilizar a San Basles y sus monjes. Ahora bien, reconocen que el hecho de que se concentren en el antiguo recinto monástico de Verzy y en tal cantidad constituye todo un «misterio para la ciencia». En otros lugares, como Hanover o los alrededores de Malmo, en Alemania y Suecia, respectivamente, el fenómeno es mucho más limitado y se halla en franco declive; en Verzy, en cambio, los peculiares «sacacorchos» no dejan de ir en aumento".

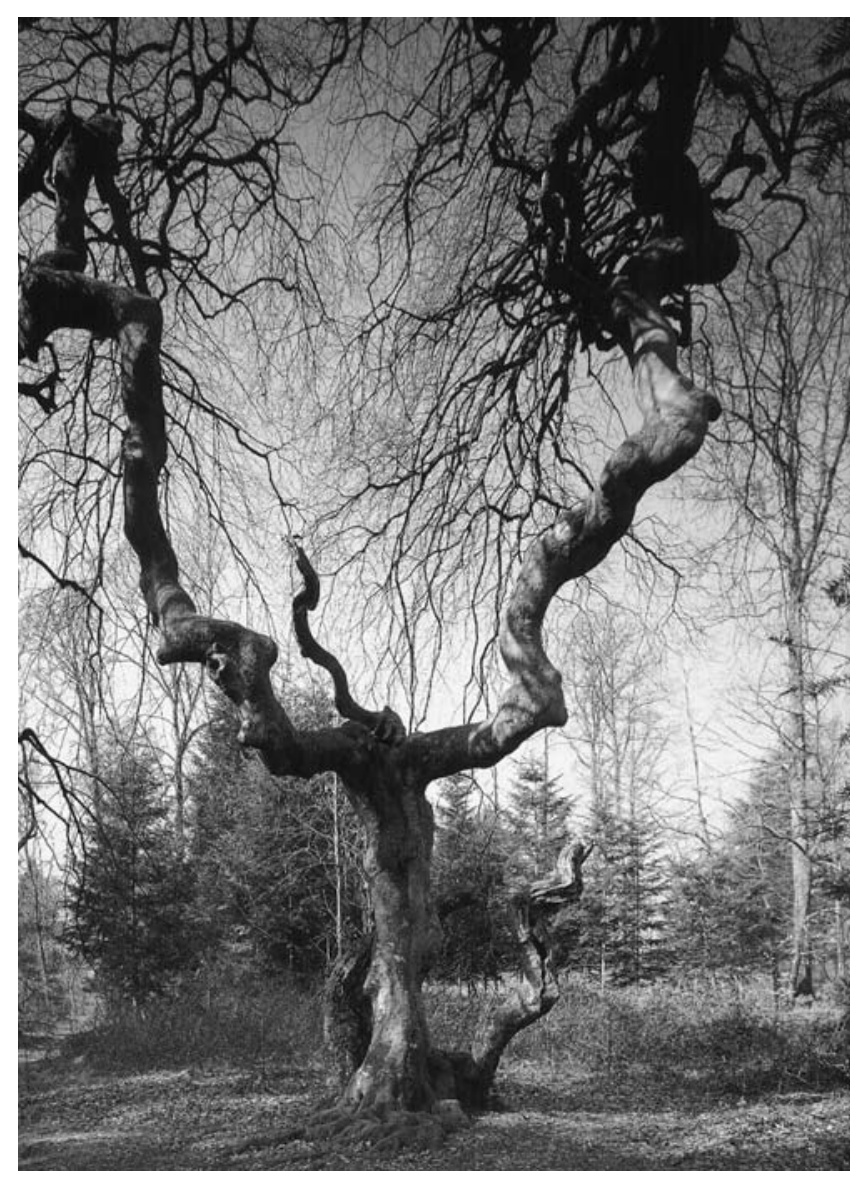

Haya "sacacorchos" del bosque sagrado de Verzy (Thomas Pakenham, 2004) 
En las postrimerías de la Edad Moderna hace acto de aparición la jardinería pública, con los paseos arbolados como precursores de las alamedas, primer establecimiento que reviste carta y naturaleza de jardín urbano público propiamente dicho. Aunque las descripciones existentes nos hablan del empleo predominante del álamo o chopo en los primeros proyectos, lo cierto es que en la composición florística de sus filas o hileras arboladas figuran otras especies (olmos, tilos, robles, castaños, fresnos, palmeras, robinias, etc.). Aunque el haya es, por derecho propio, uno de los árboles más adecuados, en base a sus cualidades y excelencias, en honor a la verdad, la información manejada no nos permite confirmar su empleo en ninguna de las alamedas dieciochescas ni decimonónicas, con la única salvedad del Paseo de Robles Americanos y de Hayas del Pazo de Casanova/O Pino, cuya plantación puede situarse en el último cuarto del siglo XIX.

Alonso López (1820) es autor de una interesante publicación, que lleva por título Consideraciones Generales sobre varios Puntos Históricos, Políticos y Económicos á Favor de la Libertad y Fomento de los Pueblos, con abundante y valiosa información botánica sobre Ferrol y su Comarca, a juzgar por los extensos catálogos florísticos de plantas de dicho ámbito geográfico: de adorno y recreo, cultivadas en los jardines, donde no figura el haya; y espontáneas o silvestres del país gallego, donde si aparece una escueta mención de esta especie forestal en el grupo de árboles que no dan fruto y que sólo tienen aplicación para diferentes obras.

Aunque la introducción de plantas ornamentales en el país gallego ya se remonta a tiempos anteriores, en el siglo XIX, sobre todo la segunda mitad, tiene lugar una entrada masiva de especies. En mi opinión, este sería el periodo temporal en el que se produce la llegada y el uso generalizados del haya, tanto del tipo silvestre como de sus cultivares. Los viveros aparecen para dar satisfacción a las necesidades creadas como consecuencia del "boom" de la jardinería y la floricultura. Nada mejor que la consulta y el manejo de catálogos de plantas editados por los establecimientos viverísticos y horto-frutícolas para su confirmación.

En opinión de Rodríguez Dacal (1990), los viveros portugueses (Establecimiento Hortícola "Marques Loureiro", Establecimiento Hortícola "Monteiro da Costa", Compañía Hortícola-Agrícola Portuense, Establecimiento Hortícola "Moreira da Silva", Establecimiento Hortícola "Jacinto de Mattos"), los viveros gallegos (Viveros Peixoto, Vivero Central de Areas, Establecimiento de Horticultura "La Caeira", Vivero de la Escuela de Capataces Forestales de Lourizán, Vivero "Torre de Lama"), los viveros del resto de España y los viveros extranjeros (franceses, belgas, italianos, etc.) han sido la vía de introducción y la fuente de suministro de buena parte de la flora ornamental. Como botón de muestra, los catálogos generales impresos en los albores del siglo XX por la Casa Jacinto de Mattos son una prueba inequívoca del material arbóreo disponible para cultivo jardinístico y forestal. La veterana haya tricolor que vegeta en Viveros Peixoto/Tui constituye un testimonio memorable fehaciente de este quehacer.
Las Libretas del Tío Iván, depositadas en el Archivo del Pazo de Santa Cruz de Ribadulla, en el término municipal de Vedra, a juzgar por el número de entradas y de citas, de plantas forestales, agrícolas y ornamentales, indiscutiblemente, son el inventario florístico de mayor envergadura y magnitud del siglo XIX en los lares gallegos. Un valioso documento que constata la llegada y la plantación del haya en el pazo en el último cuarto de dicha centuria, debido al afán introductor de Iván Fernández de Córdoba, apodado familiarmente "El Tío Iván", titular apasionado por los cultivos botánicos en todos sus frentes. En concreto, aparece en un pedido procedente de Viveros Escalante, en Luzmela (municipio de Mazcuerras/ Cantabria), con fecha de 30 de enero de 1883

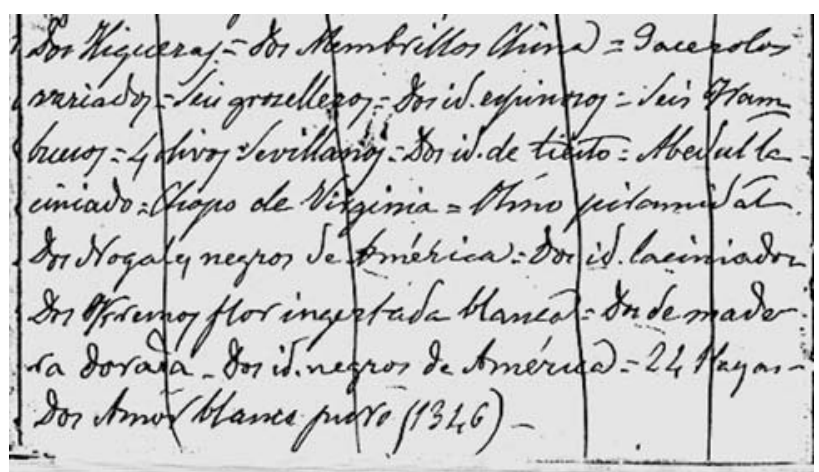

Enero de 1883. En el pedido de Escalante (Libretas del Tío Iván, Archivo del Pazo de Santa Cruz), figuran 24 hayas

Baltasar Merino (1095-1909), al referirse al haya en la Flora Descriptiva e llustrada de Galicia, deja constancia de su extremada rareza en el ámbito autóctono, por mención de los pies del Bosque de La Rogueira, en la Sierra do Courel, e incluye una substanciosa observación dentro del campo del cultivo y la ornamentación: "En la huerta de la Excma. Sra. Duquesa de Terranova, sita en San Lorenzo cerca de Santiago, hemos visto varias corpulentas Hayas; lo que prueba que tan estimado árbol puede sin dificultad prosperar por lo menos en algunos puntos de Galicia".

Rafael Areses (1953), en su libro sobre parques y jardines pontevedreses, dedica dos citas a esta especie forestal y ornamental: una al haya europea (Fagus sylvatica L.), con el número de orden 222, y la otra al haya de hojas purpúreas (Fagus sylvatica L. v. purpurea Ait.), con número de orden 223, haciendo especial hincapié de su rareza en ambos casos. Respecto al haya de tipo silvestre, reproduce la cita del Padre Merino del Bosque de La Rogueira/Lugo, donde se desplaza personalmente y confirma la existencia de varios pies añosos y corpulentos, nombrando también árboles cultivados: en el Parque del Colegio de Bella Vista (Vigo) y otros que vegetan en el Monte de Santa Tecla (vertiente Sur), al borde del sendero que va desde la Fuente Vieja a la Nueva. En relación al haya purpúrea, de la que reseña su gran efecto decorativo y su propagación por injerto sobre el tipo, alude a un par de ejemplares: el más antiguo, en el Parque del Pazo de la Merced (Tortoreos/Las Nieves), y otro en la Granja de Monteporreiro (Pontevedra), de los herederos de don Casimiro Gómez. 
Mucho le deben el haya, en particular, y el arbolado forestal y ornamental, en general, a Rafael Areses Vidal. Por eso, vayan para él estas palabras de memoria y homenaje. El día que se haga un seguimiento a su labor, podrá obtenerse la verdadera dimensión de la obra y del legado profesional de este reputado ingeniero de montes y significado botánico. En plan testimonial, decir que, a pesar de la exigua cita del trío de hayas del Monte de Santa Trega/A Garda, por el libro La Sociedad Pro-Monte Santa Tecla (Villa Álvarez, 2004), sabemos la copiosa plantación arbolada que se llevó a cabo bajo su dirección en la segunda década del siglo XX, de la que formaban parte un centenar de hayas.

El Inventario de Árboles Sobresalientes de Galicia, encargado por la Dirección Xeral do Forestal e do Medio Ambiente de la Consellería de Agricultura, Pesca y Alimentación (Xunta de Galicia, 1985), no publicado, recoge las hayas monumentales presentes en la finca de la Familia López Rioboo, en San Julián de Almeiras/Culleredo (haya péndula, 1 ejemplar); en el Campus Universitario Sur/Santiago de Compostela (haya del tipo silvestre, 4 ejemplares); en el Monasterio-Pazo de San Lourenzo de Trasouto/Santiago de Compostela (haya del tipo silvestre, 1 ejemplar); y en el Pazo de Castrelos/Vigo (haya purpúrea, 15-20 ejemplares).

Castro et al. (1989), en la Guía das Árbores de Galicia (Autóctonas e Ornamentais), confirman su rareza en parques y jardines, citando los hermosos ejemplares de haya del tipo silvestre en el antiguo Jardín Botánico de la Facultad de Farmacia/Santiago de Compostela y en el Monte Aloia/Tui, aludiendo también a las hayas purpúreas del Pazo de Castrelos/Vigo y de los Jardines de Méndez Núñez/A Coruña.

\begin{tabular}{llll}
\hline Pazo & Municipio & Provincia & Árboles \\
\hline P. de Antequeira & Rois & A Coruña & 1 \\
P. de Casanova & O Pino & A Coruña & 50 \\
P. de Miraflores & Oleiros & A Coruña & 3 \\
P. do Casal & Bergondo & A Coruña & 3 \\
P. do Picón & O Pino & A Coruña & 8 \\
P. de Santa Cruz & Vedra & A Coruña & NC \\
P. de San Lourenzo & Santiago & A Coruña & NC \\
P. de Torre de Figueroa & Abegondo & A Coruña & 2 \\
P. de Xaz & Oleiros & A Coruña & 18 \\
P. da Mercede & As Neves & Pontevedra & 2 \\
P. de Cascaxide & Silleda & Pontevedra & 1 \\
P. de Lourizán & Pontevedra & Pontevedra & 3 \\
P. de Torrecedeira & Redondela & Pontevedra & 2 \\
P. de Vista Alegre & Vilagarcia & Pontevedra & 1 \\
\hline
\end{tabular}

Pazos de la Galicia Occidental con hayas ornamentales (Rodríguez Dacal, 1990)

En la tesis doctoral Flora Leñosa Ornamental Pacega de Galicia Occidental (Rodríguez Dacal, 1990), de un muestrario total de 75 pazos coruñeses y pontevedreses, el haya aparece en 14 propiedades señoriales (9, provincia de La Coruña; 5, provincia de Pontevedra), mayoritariamente representadas por hayas del tipo silvestre, acompañadas, como variedades de cultivo, por hayas purpúreas y hayas tricolores. Como quiera que en el Pazo de Castrelos/Vigo sólo fue considerado el espacio murado en torno al palacio, en lo alto de la posesión, donde no existen hayas, y el llamado "Parque de Castrelos", que también pertenece a la propiedad original, almacena ejemplares de mucha entidad y consideración, a fuer de ser justos, debe ser contabilizado un registro más en el inventario señorial.

Siguiendo los criterios establecidos por el índice de frecuencia específica -que refleja el porcentaje de pazos en los que una especie se halla representada y establece cinco categorías (muy rara/ $<10 \%$, rara $/ 11-25 \%$, frecuente $/ 26-50 \%$, común $/ 51-$ $75 \%$ y muy común/>75\%)-, resulta que el haya se encuentra en el grupo de especies raras. Si tenemos en cuenta el índice de abundancia específica -que muestra la cantidad de individuos, por especie, presente en cada pazo, y fija cinco categorías (muy escasa/ $\leq 5$, escasa/6-10, normal/11-25, abundante/26-50 y muy abundante/>50)-, la mayoría de los pazos se caracterizan por su escasez en hayas, siendo el Pazo de Casanova/O Pino el que cuenta con más abundancia; hay dos establecimientos pacegos en los que no se han contabilizado (NC) el número de efectivos, por dificultades o impedimentos técnicos.

Como referente para comprobar la presencia del haya en los jardines urbanos públicos de nuestra geografía, nada mejor que Alamedas, Jardines y Parques de Galicia (Rodríguez Dacal, 1997a), obra que estudia más de una treintena de espacios ajardinados emblemáticos localizados en ocho núcleos poblacionales de primera entidad (A Coruña, Santiago de Compostela, Padrón, Lugo, Ourense, Caldas de Reis, Pontevedra y Vigo), repartidos por sus cuatro provincias. Del inventario jardinístico, manteniéndose la escasez que caracteriza a los jardines pacegos, el haya, del tipo silvestre y la variedad 'Purpurea', figura en los Jardines de Méndez Núñez/A Coruña, en el Parque de Santa Margarita/A Coruña, en el Campus Universitario/Santiago de Compostela, en el Jardín Botánico-Artístico/Padrón, en el Parque de Rosalía de Castro/Lugo y en el Parque-Jardín y Carballeira/Caldas de Reis.

En la actualidad, un muestreo en los espacios urbanos públicos (alamedas, jardines, parques, plazas y paseos), de las principales entidades poblacionales capitales, aporta datos reveladores de la situación del haya como especie ornamental en nuestra tierra. En Ferrol, según información de Santiago Sánchez de Toca, técnico del Servicio de Parques y Jardines, hay un seto de hayas purpúreas en la Plaza de Concepción Arenal. En A Coruña, aparece en jardines señeros (Jardines de Méndez Núñez y Parque de Santa Margarita) y -según relata Francisco García Silveira, encargado de Parques y Jardines- en otros ámbitos (Paseo Marítimo/Zona del Parrote, Plaza de Cuatro Caminos, Plaza del Almirante Romay y Calle Marqués de Figueroa/Muro de la Audiencia), con una cifra que se acerca al medio centenar de pies, verdes y purpúreos. En Santiago de Compostela, según información de José Antonio Mosquera Rodríguez, responsable del Servicio de Parques y Jardines, en diversas zonas verdes urbanas (Fontiñas/18, Alameda/3, Galeras/1, Auditorio/10, Bonaval/3, Eugenio Granell/1, Luis Pasín/1), se contabilizan en torno a una cuarentena de hayas juveniles del tipo silvestre y cultivares purpúreos. 
En Lugo, Manuel Regueiro Sánchez, jefe del Servicio de Parques y Jardines confirma que la Alameda de la Plaza Mayor y el Parque de Rosalía de Castro son las únicas localizaciones. En Ourense, José Manuel Corbal Vences, técnico medioambiental del ayuntamiento, informa de la presencia de una docena de hayas, del tipo silvestre y purpúreas, mayormente juveniles, sin superar la veintena de años, repartidas en los Jardines del Posío, Jardín de la Cárcel Vieja, Paseo de las Ninfas, Parque Barbaña y Parque Miño. En Pontevedra, a tenor de los datos facilitados por el Servicio de Parques y Jardines, se cuentan con los dedos de una mano los árboles (tres en total): en los jardines de la Plaza de Toros (1) y del Chalet de Fontoira (2), todos juveniles (25-30 años) y purpúreos. En la Ciudad Olívica, el Catálogo das Árbores Singulares do Concello de Vigo (Fernández Alonso \& Rigueiro Rodríguez, 2001) indica que existen ejemplares en distintos lugares, tanto de haya del tipo silvestre como de haya purpúrea, con especial reseña para los del Pazo de Castrelos, 9 árboles maduros con edades comprendidas entre 50 y 110 años. Relación actualizada y ampliada por Fernando Vilaboa Pérez, encargado del Patrimonio Histórico del concello, que cita nuevos enclaves urbanos públicos: Parque de Castrelos (18), Plaza de la Independencia (18), Parque del Castro (12), Plaza Eugenio Fadrique (4), Parque Forestal de Beade (1) y Rúa Progreso (masa no contabilizada, en alineación), con ejemplares verdes y purpúreos.

Personal de los distritos forestales provinciales, dependientes de la Consellería de Medio Rural y de la Consellería de Medio Ambiente, nos informan de plantíos de hayas del tipo silvestre, formando conjuntos, que no superan el medio centenar de años, en algunos espacios naturales protegidos, como elementos florísticos alóctonos introducidos en el lugar por intervención humana. En la provincia de Ourense, como rodales, figura en el Parque Natural Baixa Limia-Serra do Xurés/Entrimo, Lobios y Muíños, con mención de la especie en la guía sobre el parque publicada por la Consellería de Medio Ambiente (Pulgar Sañudo, 2005); y en el Parque Natural Serra da Enciña da Lastra/Rubiá, a donde llegó por el mismo procedimiento, junto a otros cultivos arbóreos coetáneos. También hay hayas en el Área Recreativa del Monte Faro/Chantada.

Dos nuevos instrumentos entran en escena, al final de esta reseña cronológica, para potenciar la puesta en valor de las hayas sobresalientes de los lares gallegos: la obra Árboles Monumentales en el Patrimonio Cultural de Galicia (Rodríguez Dacal \& Izco, 2003) -que recoge los individuos y conjuntos de su clase de mayor entidad del país, localizados en el Pazo de Antequeira/Rois, el Pazo de San Lourenzo de Trasouto/Santiago de Compostela, el Pazo de Santa Cruz de Ribadulla/Vedra, el Pazo da Mercede/As Neves y el Pazo de Torrecedeira/Redondela- y el Catálogo Galego de Árbores Senlleiras, elaborado desde la Consellería de Medio Ambiente e Desenvolvemento Sostible (Diario Oficial de Galicia, 2007), que incluye las hayas del tipo silvestre del Pazo de Castrelos/Vigo.

Castillo Fondevila (2003), aporta una noticia más que constata e ilustra la cultura ornamental del haya en el Fogar de Breogán. En el libro La Saleta. Jardín Botánico, incorpora el catálogo florístico de plantas cultivadas según R. Gimson, con adiciones y rectificaciones de A. Barra (septiembre de 1988-octubre de 1990). En este grandioso y sin par arboreto exótico gallego, que cuenta con un millar de especies, no figura Fagus sylvatica.

Con miras actuales y futuras, la Cidade da Cultura/Santiago de Compostela, proyecto constructivo grandioso, memorable y sin par, concebido como un espacio funcional, multidisciplinar y aglutinador, al servicio de la conservación, la producción y la exhibición de la cultura del pueblo gallego -que contempla en su entorno la creación del "Bosque de Galicia”, en la ladera oeste del Monte Gaiás, que mira hacia Compostela, en la que se establecen dos zonas diferenciadas: una superior y media, con plantaciones de abedul, avellano, serbal, acebo y tejo; y otra inferior, con castaños, robles, arces y hayas-, es un testimonio esperanzador e inequívoco de cara a la evaluación del haya como especie de ornato en los lares gallegos.

\section{Hayas cultivadas memorables}

El trabajo de campo realizado para el proyecto sobre las hayas gallegas -suscrito entre la Universidad de Santiago de Compostela y la Xunta de Galicia, recogido en el libro Os Faiais de Galicia. Ecoloxía e Valor Ambiental (Rodríguez Guitián \& Rigueiro Rodríguez/Coords., en prensa)- sobre el estudio y la investigación del uso de este señero árbol como especie ornamental en el Fogar de Breogán, me llevó hasta numerosos escenarios de cultivo, repartidos por las cuatro provincias, en torno al medio centenar; me puso en contacto con muchas personas (agentes forestales, alcaldes, concejales, técnicos municipales, viveristas, jardineros, botánicos, profesores, propietarios, caseros, etc.); y me obligó a practicar una exhaustiva labor de búsqueda y consulta de documentación y bibliografía, en archivos y bibliotecas.

Dicha colaboración evidencia, a través de sus capítulos Puesta en Valor como Árbol de Ornato, Escenarios de Cultivo y Muestrario de Hayas Memorables-, los aspectos substanciales que justifican y estructuran su contenido, científico y divulgativo. La puesta en valor del haya como árbol de ornato se centra en la enumeración y descripción general de las cualidades proporcionadas por las estructuras y partes anatómicas (raíces, tallos, troncos, cruces, brazos, ramas, hojas, flores, frutos), componentes de la arquitectura corporal, en favor de tal empresa y papel. Desde tiempos pretéritos, el haya, tanto los ejemplares del tipo silvestre como las variedades de cultivo, es una de las especies de empleo habitual, para beneficio de sus valores jardinísticos y paisajísticos, gozando del culto y la veneración de gentes y profesionales. La demostración de la consideración popular se hace patente por los escenarios de cultivo, públicos y privados, teniendo cabida en pazos, castillos, bienes eclesiásticos, balnearios, fincas particulares, viveros, ámbitos escolares, jardines municipales urbanos públicos y espacios naturales; con claro predominio, por este orden, para los pazos y los jardines municipales urbanos públicos. En Galicia, hay constancia del cultivo del haya, cuando menos, desde la 
segunda mitad del siglo XIX, por lo que, desde entonces hasta hoy, ha transcurrido tiempo suficiente para contar con un significado muestrario de fagus memorables, con representantes en el patrimonio vivo y en el patrimonio desaparecido.

Ha dado tanto de sí el trabajo de campo que, por razones de espacio, no ha sido posible incluir en el libro (Rodríguez Guitián \& Rigueiro Rodríguez/Coords., en prensa) toda la información recopilada. Como quiera que no es menos importante, a través del artículo de la revista se ofrecen nuevos datos y noticias que complementan el contenido científico de dicha publicación. Datos y noticias que permiten al lector hacer una caracterización individualizada de todos y cada uno de los registros memorables, mediante una interesante y copiosa colección de apuntes históricos, culturales y botánicos. Con el fin de facilitar la consulta de datos geográficos y biométricos de hayas memorables vivas y desaparecidas, reproducimos al final los cuadros correspondientes, tomados de Rodríguez Dacal (en prensa).

\section{Hayas del Pazo de Xaz/Oleiros}

Citadas por Rodríguez Dacal (1990), se localizan en el bosquete ornamental de acceso al pazo, que consta de alineaciones alternadas e intercaladas de pinos y fagus, abundando más los primeros que los segundos. Con 15 hayas de tipo silvestre, se puede afirmar que este escenario señorial constituye uno de los principales reservorios de cultivo y adorno de la especie en Galicia, contribuyendo a magnificar su puesta en valor la edad de la arboleda, por tratarse de una plantación coetánea del proyecto jardinístico materializado a principios del siglo XX. Por su indiscutible categoría, el pazo sube muchos enteros la cotización de las hayas.

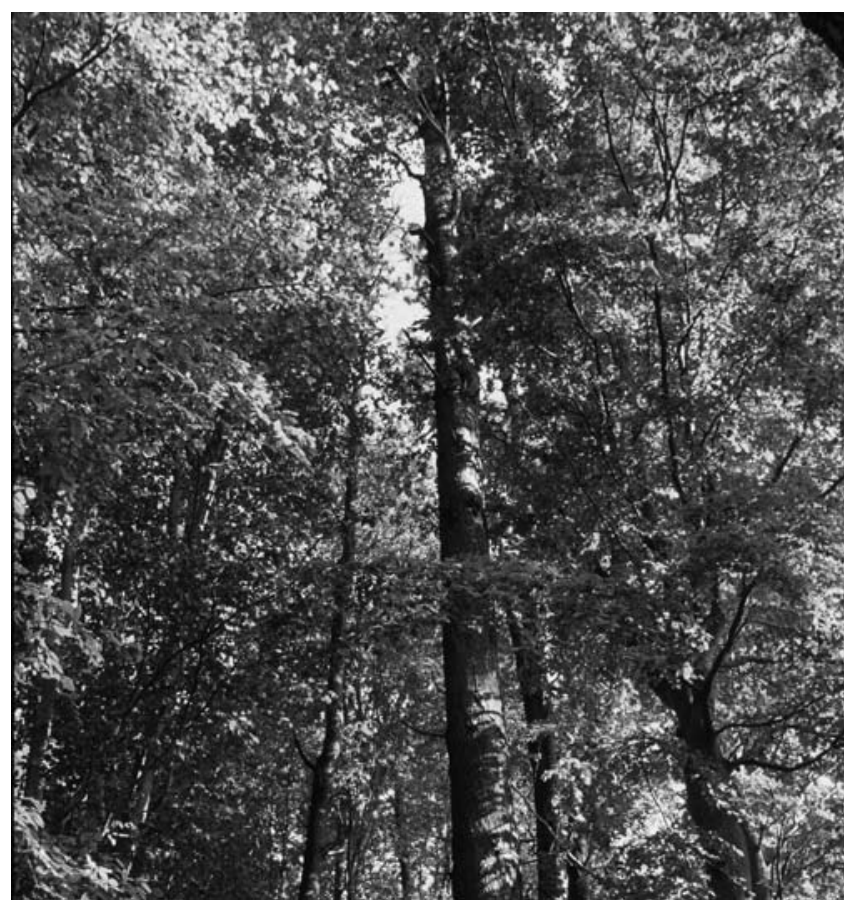

Hayas del Pazo de Xaz/Oleiros
El arbolado del bosquete está sometido a fuerte competencia, defendiéndose mejor el pinar que la masa de hayas, dispuesta en hileras, con distancias mínimas de separación, tanto entre filas como entre individuos. Los ejemplares muestran similitudes en el protagonismo troncal y los portes esbeltos, de tipo columnar, con notables mermas volumétricas copales. Aunque se notan diferencias dendrométricas, todos pertenecen al plantel original.

\section{Hayas del Pazo do Casal/Bergondo}

Por la caracterización de sus dominios territoriales, el Pazo do Casal es un jardín de jardines, cuya entidad botánica potencia en buena medida la valía de la pareja de hayas del tipo silvestre, que vegetan en uno de los bosques-jardín más antiguos y señeros del país, a pesar del estado de abandono actual. Bosquete murado, desarrollado sobre un terreno de topografía pendiente, correspondiente al valle de un regato, con presas y saltos de agua. Setos arbustivos enmarcan la red de caminos, orillando cuadros polimorfos formadores de un jardín ecléctico con querencia paisajista. Cuadros poblados por densa masa leñosa, que crece en desorden y libertad, dominada por eucaliptos y laureles, acompañados por otras especies ornamentales.

Las hayas viven en la zona alta, al lado del camino que transcurre paralelo al muro separador del jardín hortícola, tratándose de árboles con troncos monopódicos poderosos y copas de mala hechura, fruto de la fuerte competencia impuesta por el arbolado vecino, muy desequilibradas por descompensación de los desarrollos ramificacionales, alcanzando las mayores expansiones volumétricas hacia el jardín hortícola, donde ofrecen la mejor cara y campo visual, libre de vegetación.

\section{Hayas de los Jardines de Méndez Núñez/A Coruña}

Tiene a su favor, el trío de hayas, razones biométricas edad, talla y grosor troncal-; buen estado de conservación, físico y saludable; referencias bibliográficas (Prunell Tuduri et al., 1987; Rodríguez Dacal, 1997a); y la categoría del jardín, uno de los establecimientos urbanos más reputados del Finisterrae.

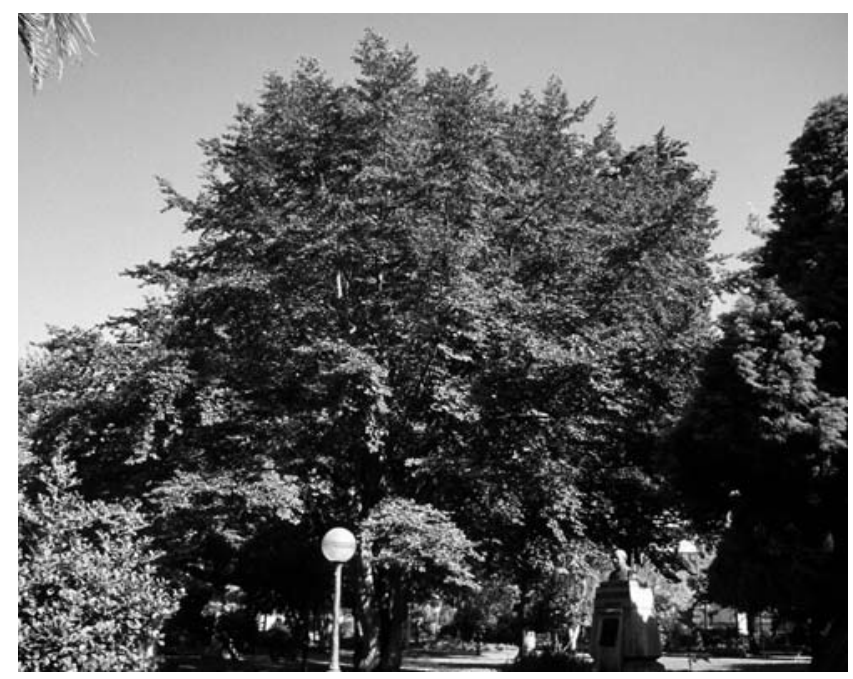

Haya Purpúrea de los Jardines de Méndez Núñez/A Coruña 
El haya purpúrea es el ejemplar de mayor precio, con una arquitectura copal espectacular, frondosa y umbrosa, de silueta aovado-redondeada, sobre tronco corto y poderoso, generador de un cuarteto de brazos que pronto se transforma en quinteto por división. El entorno arbolado, que aprieta pero no ahoga, y la nómina de monumentos (al Doctor Hervada, al Año Internacional del Niño/UNICEF y a Juan Fernández Latorre) mejoran la evaluación del haya, así como el hecho de tratarse de una variedad de hojas purpúreas. La pareja de hayas del tipo silvestre, bien conservadas, de apreciables portes, acusan el habitáculo espacial minimalista que merma sus cuerpos y restringe los campos visuales. La proximidad a monumentos (Castelao y Murguía, en un caso; y Emilia Pardo Bazán, en el otro), ayuda a la localización y consideración de ambos pies, de troncos cortos, cruces bajas y cuatro brazos, con soldaduras.

\section{Hayas del Monasterio de Santa María/Sobrado}

La colección, con 28 ejemplares, es la más cuantiosa que alberga un parque monacal en nuestra tierra, repartiendo por igual sus efectivos purpúreos y del tipo silvestre. 14 de las 15 hayas purpúreas -bien conservadas y con portes reducidos- se alinean en la zona alta del parque, actuando como pantalla de separación con la granja y el agro, intercaladas con liquidámbares y acebos variegados, remontándose su plantación a principios de la década de 1990. Las hayas del tipo silvestre, 13 en total, aparecen dispersas por el recinto y corresponden a diversos momentos plantacionales, datando las más antiguas (los tres pies medidos), de mediados de la década de 1980, notándose su mayor edad en las dendrometrías y desarrollos volumétricos conseguidos, siendo coetáneas con la creación del espacio ajardinado. La información cronológica de los fagus fue facilitada por Jaime Lamas Calvete, monje de la comunidad religiosa.

El parque -de carácter paisajista y piso encespedado, ante las fachadas del mediodía y del naciente, con varias hectáreas en su haber- se distingue por su riqueza arquitectónica y natural, hecho que repercute positivamente en la valoración de las hayas, junto con el marco de asentamiento, representado por uno de los monasterios más grandiosos de Galicia. A tenor de la diversidad florística, que es extraordinaria, adquiere la categoría de arboreto.

\section{Hayas del Pazo do Picón/O Pino}

Rodríguez Dacal (1990) aporta la primera cita bibliográfica de las hayas de tipo silvestre que viven en la huerta pacega. Grupo de árboles, compuesto por media docena de troncos principales, de diversos grosores, dispuestos en hilera tan prieta que caben todos en tres metros. La proximidad plantacional nos obliga a ser cautos a la hora de hacer el contaje individual por no estar claro si algunos de los efectivos corresponden a retoños basales emitidos por los ejemplares de mayor edad.

Hemos practicado dendrometría en los ejemplares más corpulentos, que se encuentran en ambos extremos: sendos árboles muestran hendiduras troncales verticales, más patentes en uno que en el otro, hasta la formación de las respectivas horquillas, hecho que invita a pensar que se trate de parejas de fustes soldados desde la zona basal por injertos de aproximación. Soldaduras cuya formación se percibe con claridad en los dos pies centrales del grupo, cuyo paralelismo basal está en fase de tocamiento, siendo el injerto de contacto el destino final con el andar de los años. Troncos y brazos crecen verticales y derechos hacia lo alto, ramificando y construyendo portes estrechos y elevados, que se entremezclan y configuran una arquitectura copal única, aovado-redondeada.

\section{Paseo de Hayas del Pazo de Casanova/O Pino}

Avenida arbolada, en doble fila, que comienza y remata con robles americanos, y se completa con hayas del tipo silvestre en su tramo central. El toque de excelencia en la composición del paseo corresponde a las hayas, ante la homogeneidad estructural de la formación, por la elegancia y esbeltez de los portes, por la genuina umbrosidad y por la belleza fisionómica que emana del conjunto y de cada uno de sus árboles integrantes.

Las hayas -en número de 47, faltando algunos efectivos del plantel original: Rodríguez Dacal (1990), habla de 50 ejemplares- se reparten por igual en ambas orillas, con una separación entre pies alrededor de $4 \mathrm{~m}$, a lo largo de un

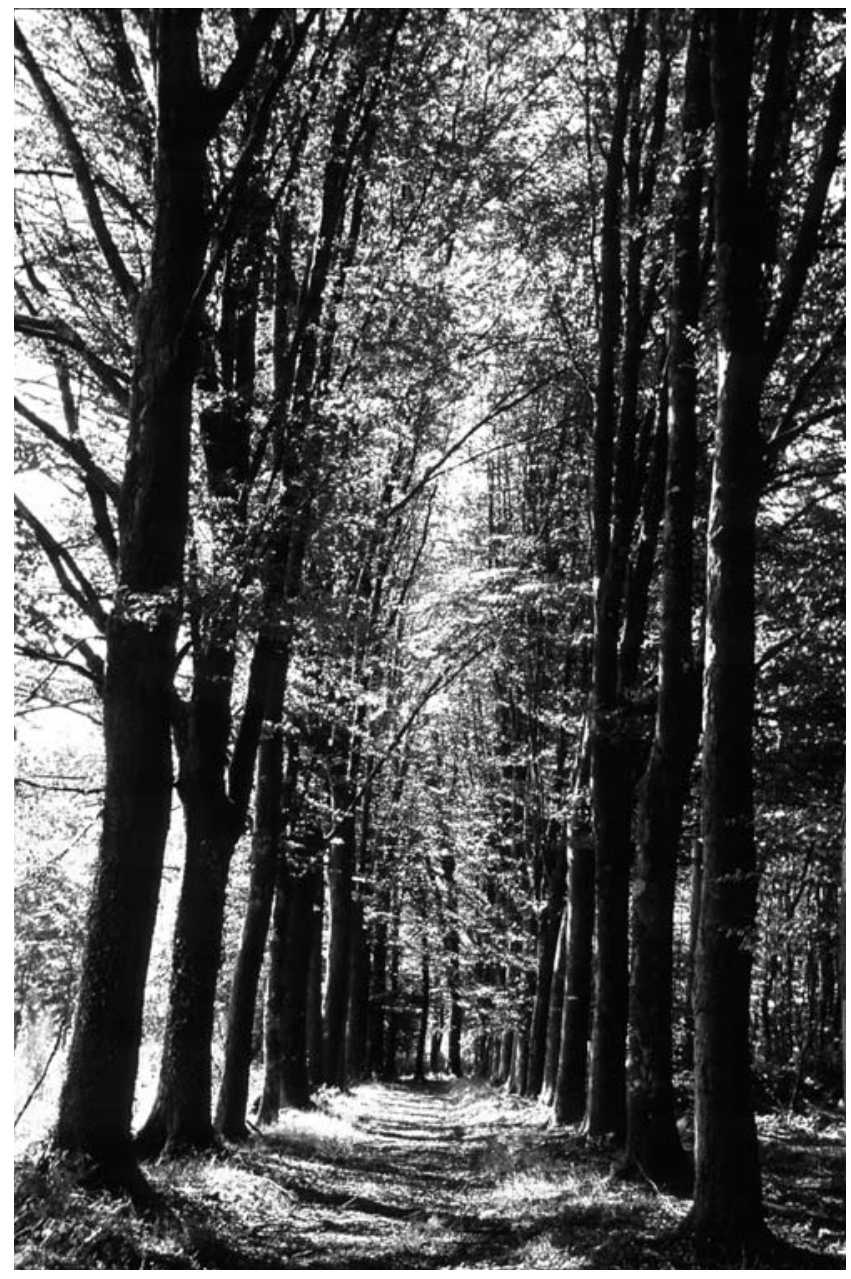

Paseo de Hayas del Pazo de Casanova/O Pino 
recorrido que supera ligeramente $100 \mathrm{~m}$. Los árboles responden a un mismo modelo corporal, con troncos monopódicos de distinta altura, predominando los elevados, y horquillas descompuestas en brazos que ascienden apretadamente hacia la cima, abriéndose las copas por ramificaciones sucesivas, primando los portes estrechos de considerable medida, hasta el punto que en esta singular vereda viven los individuos cultivados con fines ornamentales de mayor talla de Galicia. El propietario actual, Manuel Alonso-Martínez Grisone, informa que la creación del paseo pudo ocurrir en tiempos de Ramiro Hernán Luyando y Varela de Luaces; confirma también la germinación espontánea de hayucos, desde siempre, y la falta de viabilidad de los plantones generados, al cabo de unos años, sin saber el porqué de su desaparición.

\section{Hayas del Pazo de San Lourenzo/Santiago}

No se ha contabilizado el número exacto de pies, que supera con creces las dos docenas sin alcanzar el medio centenar, concentrados sobre todo en el bosque, con una señalada nómina de "viejas glorias", donde se comprueba fácilmente la capacidad germinativa. Es todo lo que suma el pazo compostelano, que es mucho, a la causa del haya como especie ornamental. Como tónica general, los árboles están bien conservados, provistos de troncos corpulentos y amplias volumetrías copales, a pesar del agobio que padecen, notándose como el haya siempre gana la partida a la hora de competir con otras especies.

Todos los ejemplares medidos superan la veintena de metros de talla, moviéndose en un intervalo de valores comprendido entre 21-24 m. En lo tocante a grosor troncal,

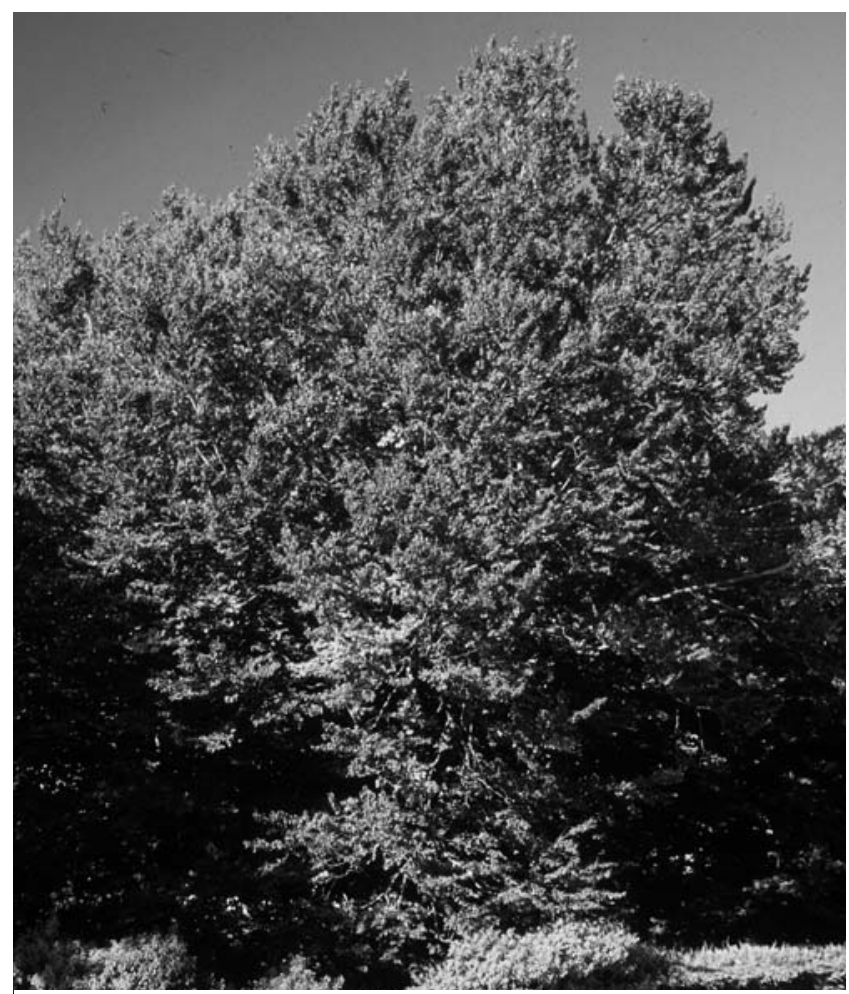

Haya del Monasterio-Pazo de San Lourenzo/Santiago en el Jardín en Terrazas, el Haya de la Glorieta (2,97 m) ocupa el primer lugar, seguida del Haya de la Pajarera $(2,89$ $m$ ). En el Bosque, vive una población de hayas seculares con circunferencias de fuste muy próximas a las indicadas, de las que se citan, por su fácil localización y por su mejor visualización, el Haya del Lavadero $(2,74 \mathrm{~m})$, el Haya del Gallinero $(2,73 \mathrm{~m})$ y el Haya del Alpendre $(2,70 \mathrm{~m})$. Las Hayas del Jardín Paisajista (hay tres, alineadas al borde del camino, encabezadas por la de $2,46 \mathrm{~m}$ ) y el Haya del Pozo $(2,33 \mathrm{~m})$ poseen valores menores.

La plantación del haya con fines ornamentales -que tiene en Leiro Lois et al. (2006) la última cita bibliográfica-, en sentido amplio, se sitúa en la segunda mitad del siglo $\mathrm{XIX}$, presumiblemente en el último cuarto, coincidiendo con el proceso de restauración y ajardinamiento acometido. Como aval de tal afirmación, hay un dato documental, contenido en la Flora Descriptiva e llustrada de Galicia del Padre Merino (1905-1909), que noticia la presencia de varias hayas corpulentas en el pazo. Sin duda, los portes alcanzados por los árboles vistos, con dos a tres décadas en su haber vital, a buen seguro, llamaron la atención de este sabio que tanta contribución prestó al conocimiento y progreso botánico del Fogar de Breogán.

\section{Hayas del Campus Universitario/Santiago}

Vegetan en una parcela terrenal del Campus (entre los pabellones residenciales, el campo de fútbol y la piscina), poblada de arboleda multiespecífica vetusta, donde los plátanos de sombra destacan por razones numéricas mientras que, por cualidad, lo hace el cuarteto de hayas del tipo silvestre -citado en diversas publicaciones (Cid González \& Chouza Mata, 1982; Chouza Mata \& Cid González, 1986; Marisa Castro et al., 1989; Xunta de Galicia, 1985)-, asociado al Jardín Botánico de Fonseca, sin descartar su posible relación con el vecino Monasterio-Pazo de San Lourenzo. Cuarteto que sobresale por las excelencias emanadas de todos y cada uno de los individuos, con soberbios aparatos corporales caracterizados por las significadas volumetrías, el buen estado fitosanitario y el impacto que produce su observación unitaria y grupal.

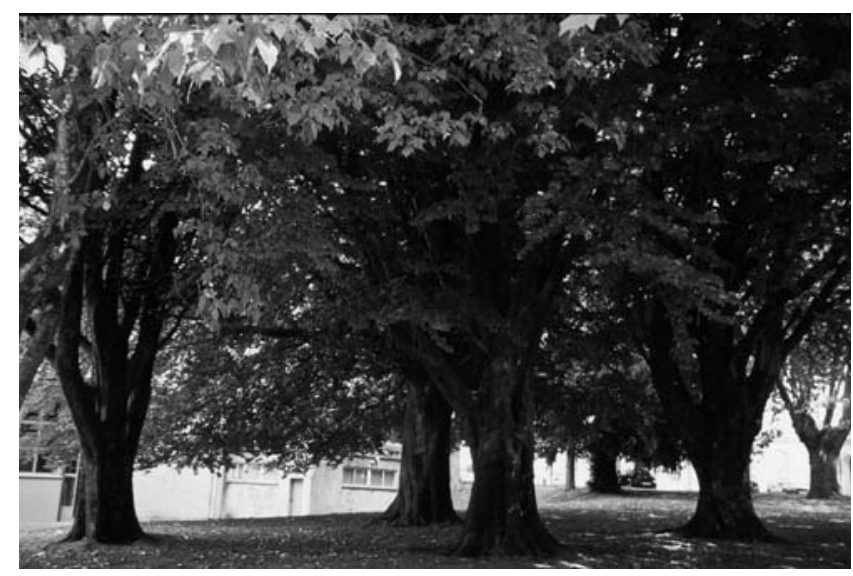


Hayas portadoras de troncos monopódicos, de poca elevación, asentados sobre raigales que dejan ver sus arranques antes de enterrarse. Con cruces de poderosos brazos, que se dirigen apretadamente hacia lo alto, para acabar generando arquitecturas abiertas, que entremezclan las ramificaciones y dan como resultado, en visión lejana, una gran copa única que se ajusta al contorno aovadoredondeado. Hay que lamentar el doble cinturón, arquitectónico y vegetal, que limita y restringe su campo visual, sobre todo la masa arbórea circundante.

\section{Hayas Centro Agroforestal Sergude/Boqueixón}

Son cuatro las hayas del tipo silvestre depositadas en el centro escolar, otrora Pazo de Quián. Según información de Salvador Barros Nogueira, profesor del centro, las hayas, como plantones en torno a $1 \mathrm{~m}$ de altura, proceden de los viveros del Pazo de Lourizán/Pontevedra, efectuándose su plantación en 1990 en los lugares que ocupan del jardín paisajista. Años después, un vendaval produjo el desgajamiento de uno de los brazos del ejemplar solitario que reside al lado del chalet, que rasgó hasta la base el cilindro troncal, aprovechándose tal circunstancia para la práctica de un injerto de aproximación con los alumnos.

El haya aislada, en vecindad al chalet, consta de fuste bajo pero poderoso, con notable circunferencia, no ocultando la soldadura de las dos partes que han crecido juntas, visible por la escotadura y el entrante en la zona de contacto. A partir del primer metro, se abre la cruz, con brazos y ramas que presentan nuevas soldaduras, de distinta magnitud. EI trío de hayas restantes (frente al edificio señorial y la capilla), de hechuras parecidas aunque con diferencias volumétricas, mezclan sus arquitecturas por la proximidad de la plantación, generando un cuerpo común en la Iontananza, aunque de cerca se divisan e individualizan con claridad.

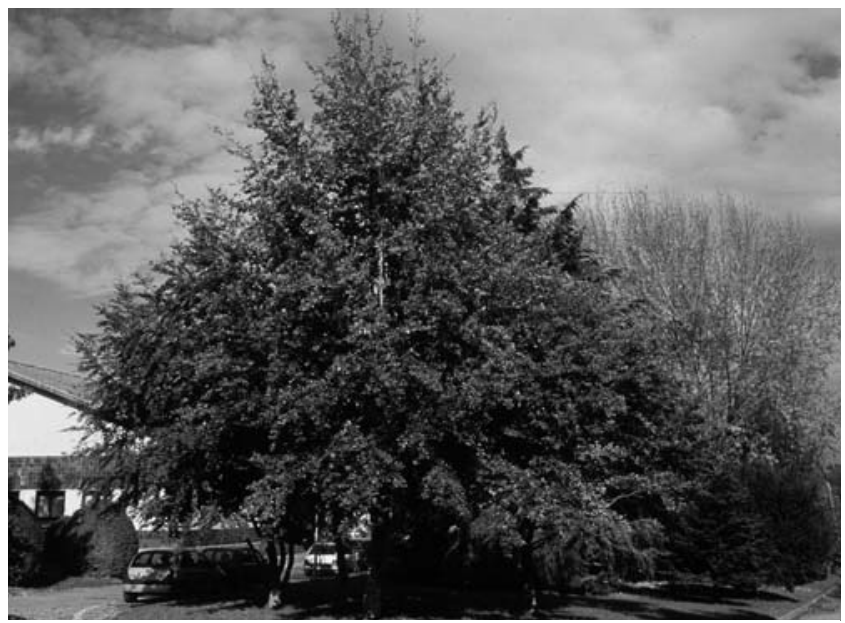

Hayas del Centro Agroforestal de Sergude/Boqueixón

\section{Hayas del Pazo de Santa Cruz de Ribadulla/Vedra}

Un pedido procedente de Viveros Escalante (Luzmela/ Mazcuerras), con fecha de 30 de enero de 1883, donde figuran 24 ejemplares, citado en las Libretas del Tío Iván (Archivo del Pazo de Santa Cruz de Ribadulla), aporta valiosa información para la averiguación de la llegada del haya del tipo silvestre a la noble propiedad, junto con la determinación de su edad. Por lo que se ve, el Tío Iván optó por el bosque como lugar de plantación. Se han seleccionado y medido los tres representantes más sobresalientes. En número no determinado, las hayas aparecen en la tesis doctoral de Rodríguez Dacal (1990), así como su localización en el pazo; Leiro Lois et al. (2006) citan en su libro uno de los ejemplares monumentales.

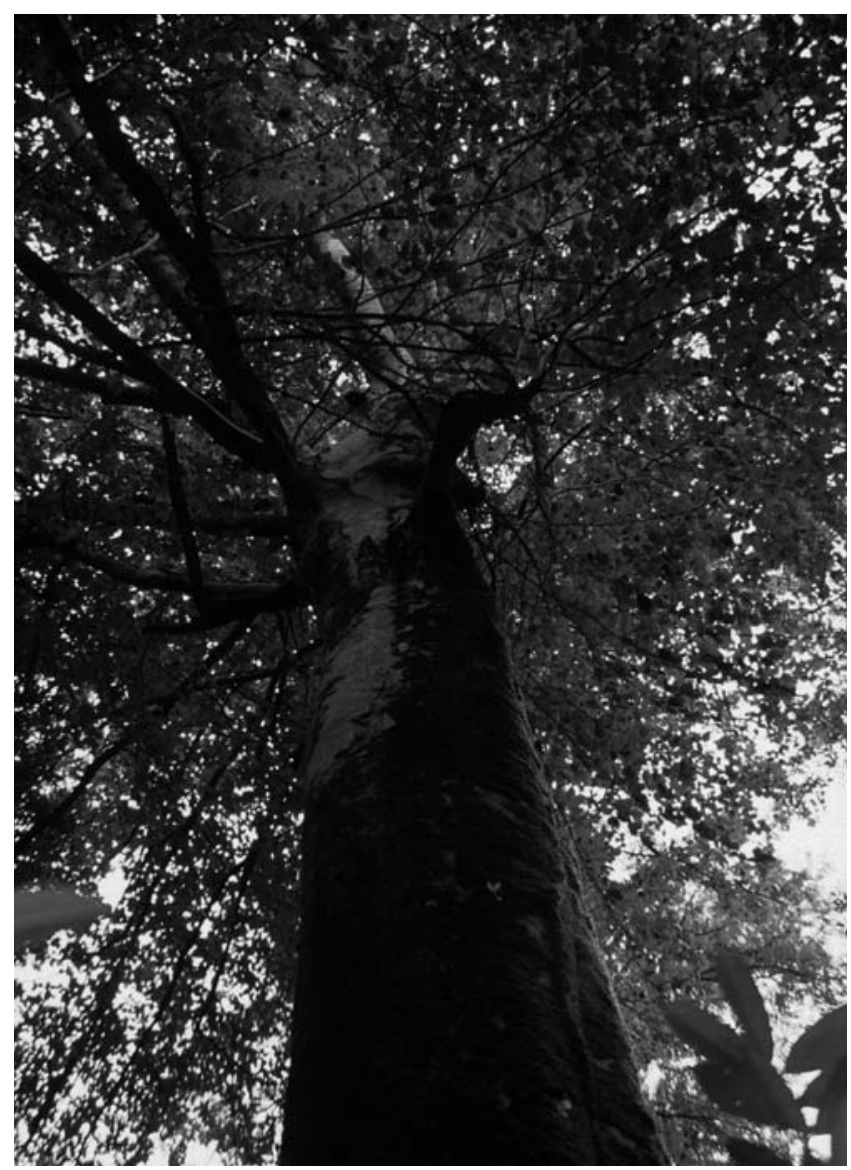

Haya del Pazo de Santa Cruz de Ribadulla/Vedra

Desde la espectacular cascada del Regato Castilán, caminando por la carrera de bojes, hasta la Plazuela de Jovellanos, a pocos metros del rústico puente de madera cercano a la cascada, algo apartada del sendero, pero muy visible por su corpulencia, aparece el primer ejemplar. Unos pasos adelante, al borde de la vereda, está el segundo, que impresiona por la fisionomía y la derechura del tronco sin par, que alcanza la mayor perimetría y elevación del grupo. Más cerca de la plazuela, se localiza el tercero, en la otra orilla, lindante con el regato, pie de menor grosor del trío.

Todos juntos, presentan una serie de afinidades, al ser portadores de enormes tallas, superiores a $40 \mathrm{~m}$; fustes poderosos, más o menos altos, que crecen rectos y verticales hasta la cruz, cuyos brazos salen próximos y suben hacia lo alto, originando copas de mucha envergadura aunque con menor volumetría de lo habitual por la competencia ambiental. 


\section{Haya del Jardín Botánico-Artístico/Padrón}

Con motivo de la celebración del Día del Árbol 1996, se plantó el Haya de Don Luis. Luis de Dios Rey, ya fallecido, profesor del CEIP Rosalía de Castro/Padrón hasta su jubilación, llegó a las tierras rosalianas desde Cantabria, donde ejerció su labor magistral en Barruelo de Valle de Ruesga, lugar poblado de frondosos hayedos cuya contemplación quedó grabada en la memoria del maestro. Un intercambio escolar, entre alumnado de centros (Padrón/A Coruña y Astillero/Santander), produjo la llegada del haya del tipo silvestre, como elemento de hermandad entre ambas comunidades educativas, que el protagonista de esta historia regaló al Jardín Botánico-Artístico. Una placa recuerda el evento: "Faia, procedente do/Val do Saja -Cantabria-,/Plantada co Gallo da/Celebración do Día da/Árbore. Doazón do Profesor/Luis de Dios Rey./Padrón, 22 de Marzo de 1996".

El valor simbólico, antes que los méritos propios por tratarse de un árbol joven, y el hecho de vegetar en un jardín tan emblemático, son las causas que motivan su inclusión en el inventario de hayas memorables. En el libro Alamedas, Jardines y Parques de Galicia (Rodríguez Dacal, 1997a), aparece una breve reseña de la fagácea.

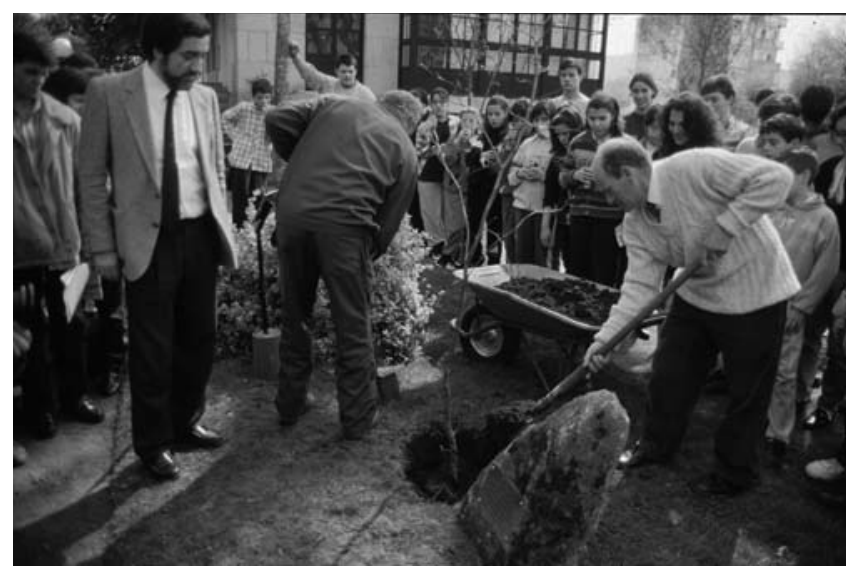

Luis de Dios Rey plantando el haya en el Jardín Botánico/Padrón

\section{Haya del Pazo de Antequeira/Rois}

Árbol de cuerpo sensacional, desde el suelo hasta la cima, asentado sobre un raigal superficial consistente que invade el camino del paseo de bojes del que forma parte. Un tronco formidable, cilíndrico y macizo, protagoniza los primeros metros hasta que origina la horquilla, compuesta por un tridente de brazos poderosos que arrancan juntos, en ángulo agudo, descomponiéndose en un sistema de ramificación abierto. A pie de fuste, una mirada hacia arriba permite contemplar la arquitectura espectacular, que adopta hábito cupuliforme, convirtiendo al ejemplar en una especie de glorieta umbrosa.

Provisto de un campo visual de mucha amplitud para su contemplación, llama la atención el extraordinario grado de desarrollo volumétrico conseguido, el grado de vitalidad y la frondosidad que lo caracterizan, así como la integridad física y la buena salud que muestra en su condición secular, siendo plantado probablemente en la segunda mitad de la centuria decimonónica, coetáneo con la creación del recinto jardinístico. Es una de las hayas de tipo silvestre más señeras del patrimonio gallego, incluída en la tesis doctoral de Rodríguez Dacal (1990) y en el catálogo arbóreo monumental (Rodríguez Dacal \& Izco, 2003), por méritos propios (porte, edad, conservación) y el lugar de asentamiento, el señorial Pazo de Antequeira, testimonio de la arquitectura barroca dieciochesca del País Ullán.

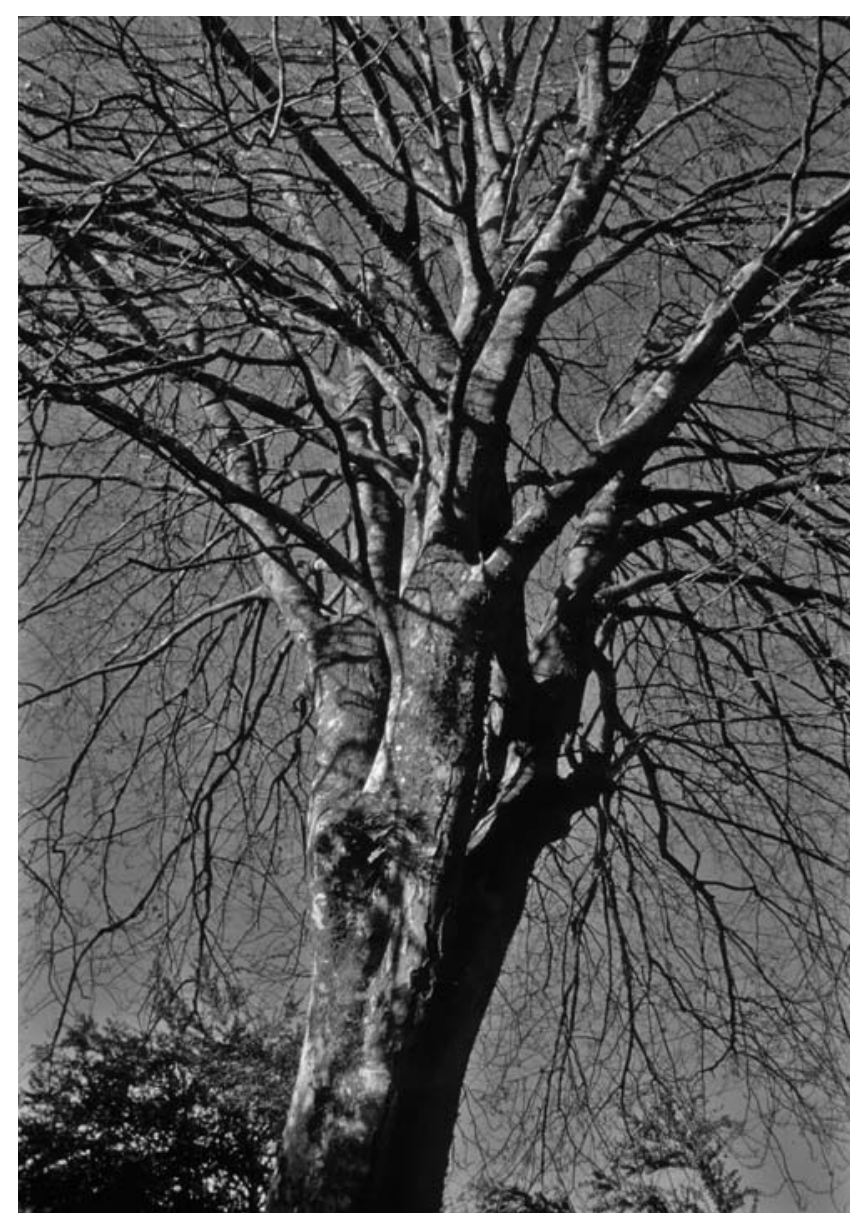

Haya del Pazo de Antequeira/Rois

\section{Hayas del Monte Faro/Chantada}

Un área recreativa habilitada en una vaguada de la cima del Monte Faro, en un entorno de pinar (pino silvestre), contiene uno de los colectivos de hayas del tipo silvestre que vive a mayor altitud del país -una docena, en total-, del muestrario de ejemplares plantados en la red de escenarios seleccionados y visitados para la catalogación de hayas cultivadas memorables. Hecho que importa de cara a la valoración de estos árboles, junto con la situación que ocupa, en un lugar de importancia comunitaria/LIC.

El área recreativa, en un terreno de fuerte pendiente, cuenta con arbolado multiespecífico en alineación, dominado por el pino y el abedul, en compañía de otras especies (carballo, castaño, roble americano, alerce y haya), correspondientes a la misma fecha introductoria, salvo la masa de pinos, en 
la zona alta y lindante con la pista, cuyo mayor porte denota su anterior llegada. A decir de José González Vila, Jefe Comarcal de Montes hasta su jubilación, la creación del área recreativa y el plantel de árboles datan de 1989-1990, aproximadamente, figurando las hayas en el grupo ornamental por consejo personal, procedentes del Vivero Os Trollos/Bóveda, propiedad de la Xunta de Galicia, transportadas como plantones de poca edad, en torno a un metro de altura.

\section{Haya del Balneario/Guitiriz}

El parque, que responde al modelo de bosque-jardín, a tenor de la estructura y la disposición de las masas arboladas, en sectores bien definidos, por el protagonismo de las coníferas y del abedul; el campo de golf, extensa alfombra de verdor; y el grandioso edificio residencial, que luce sus mejores galas constructivas, son los logros y atractivos que brinda el establecimiento termal a los aguistas que lo visitan. Al fondo de la finca, en posición extrema y alejada, en un cruce de caminos que aparece a la entrada de una plazuela -a la que se llega siguiendo en paralelo al campo de golf, el regato y los puentes que lo cruzan-, a la izquierda del tee $n^{\circ} 1$, se localiza el haya de tipo silvestre.

Ejemplar, de porte esbelto y elevado, cuya copa padece un importante proceso de sequedad y defoliación ramal. Aunque, externamente, no se observan pudriciones,

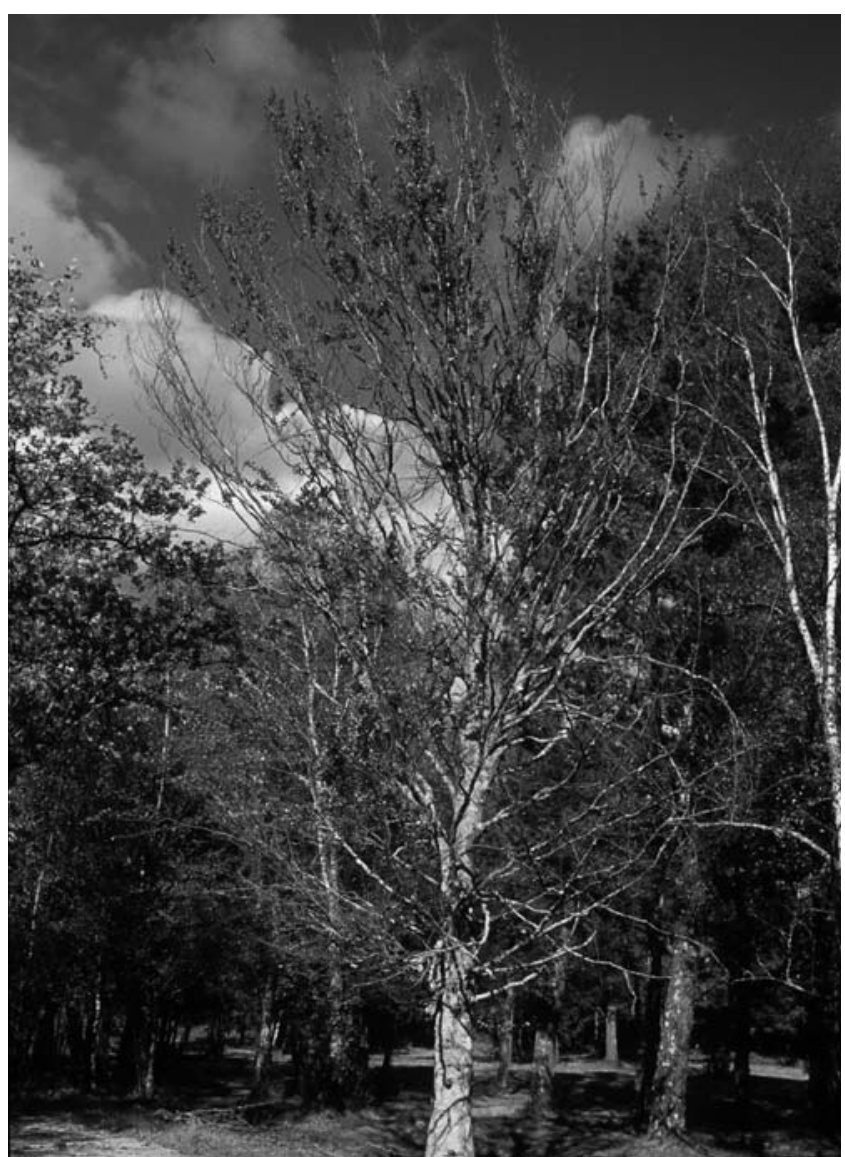

Haya del Balneario de Guitiriz oquedades e infecciones, ante la cantidad del ramaje afectado, como remedio a tal situación, se aconseja la práctica de una poda de formato y vigorización. Puesto al habla con el personal de la empresa, me confirman la considerable mortandad de árboles en los últimos años, que asocian con las emisiones de la central térmica de As Pontes de García Rodríguez, pareciendo que el haya sea otro de los candidatos condenados a seguir el mismo destino.

\section{Haya de la Casa Souto Montenegro/Begonte}

Pegada al muro pétreo delimitador del patio y al lado de la cerca pizarrosa separadora de la pista, se encuentra un haya del tipo silvestre de hermosa hechura fisionómica, buena conservación, mucha umbrosidad e impresionante dendrometría en todos sus aspectos: alta talla, elevado tronco y cuantiosa volumetría arquitectónica.

Es propietaria de un fuste cilíndrico y vertical que va emitiendo ramas menores hasta la formación de la cruz, a siete metros, dirigiéndose la pareja de potentes brazos en estrecho ángulo agudo, casi paralelos, hacia lo alto, ramificando con profusión para formar en conjunto una gran copa, que se extiende y abarca casi desde el suelo hasta la cima. Aunque padece las molestias causadas por un carballo y un nogal, de considerables tamaños, el haya ha ganado la partida, haciéndose con su sitio sin muchos problemas.

\section{Hayas del Bosquete das Modias/Begonte}

El Bosquete das Modias es un referente natural señalado en el núcleo poblacional, por razones de situación -entre las tierras del iglesario (Iglesia Parroquial de San Pedro, con su atrio, y casa rectoral), el cementerio municipal, el colegio público y las viviendas del lugar, de las que forma parte, a cierta distancia, la Casa de Souto Montenegro)- y valores propios que emanan del rodal de hayas y carballos, por su significado y edad. Bien municipal urbano que, en palabras del alcalde, José Pena Rábade, va a ser acondicionado para conferirle un cometido lúdico-recreativo.

Bosquete de hayas y carballos que reparten por igual sus efectivos, siendo más evidente el protagonismo de las hayas, del tipo silvestre, por el gran desarrollo volumétrico de sus copas en comparación con el escaso espacio disponible. Todos los árboles, una decena, de dendrometrías y antigüedad parecidas, bien conservados, exhiben portes de similares características, con preponderancia de los ejes troncales, que suben bastantes metros hasta las horquillas, cuyos brazos emiten en abundancia ramificaciones en todas las direcciones, de distintos calibres y longitudes, responsables de las siluetas aovado-globosas individuales.

\section{Haya del CEIP Virxe do Corpiño/Begonte}

La construcción del CEIP Virxe do Corpiño, hace casi tres décadas -que supuso la separación de la finca escolar, mediante vallado, del entorno original de pertenencia, el Bosquete das Modias-, ha motivado la posición más sorprendente, de todo el colectivo de hayas ornamentales inventariadas: un ejemplar que ha quedado atrapado en medio de dos tramos de la cerca de hormigón. La previsión 
del espacio habilitado en el cierre perimetral, permitirá al haya seguir engordando su fuste durante años y décadas sin problemas de contactos y estrangulamientos.

El haya del colegio, que goza de amplio campo visual, presenta algunas características propias que la distinguen de los compañeros del bosquete, no sólo por su peculiar situación sino también por su bella hechura, donde el sorprendente raigal se convierte en

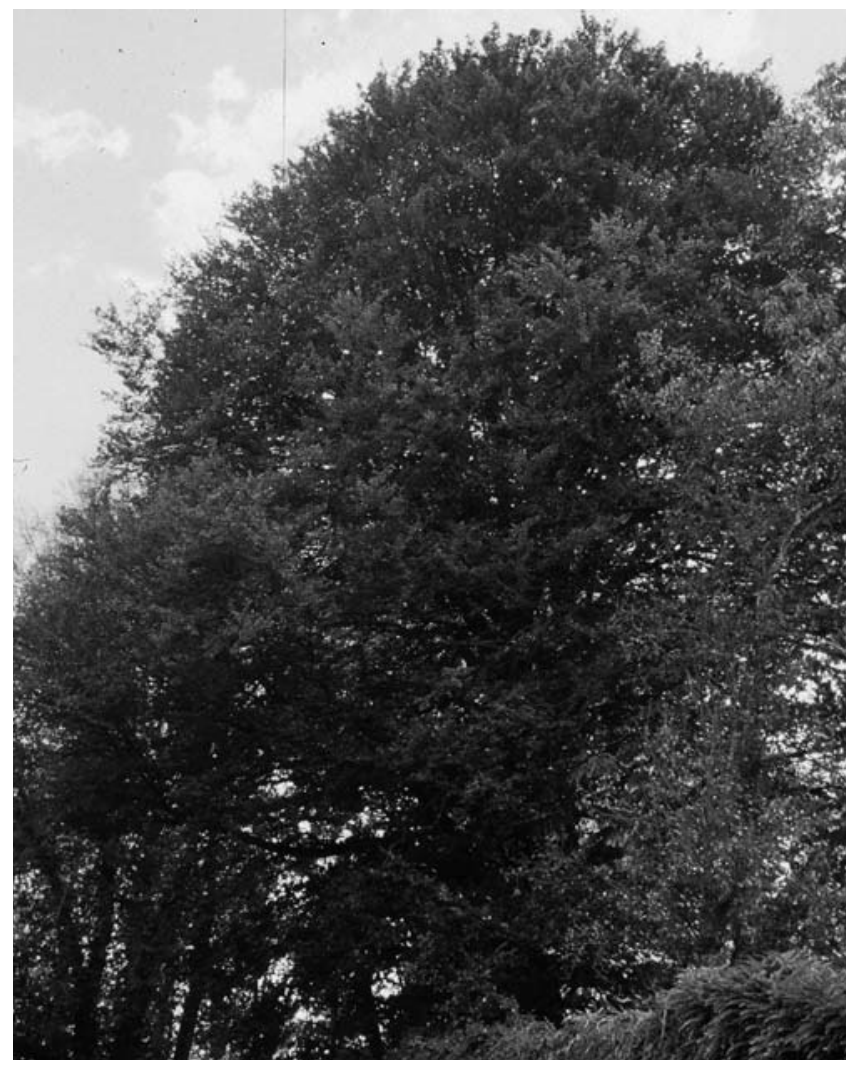

Haya de la Casa Souto Montenegro/Begonte
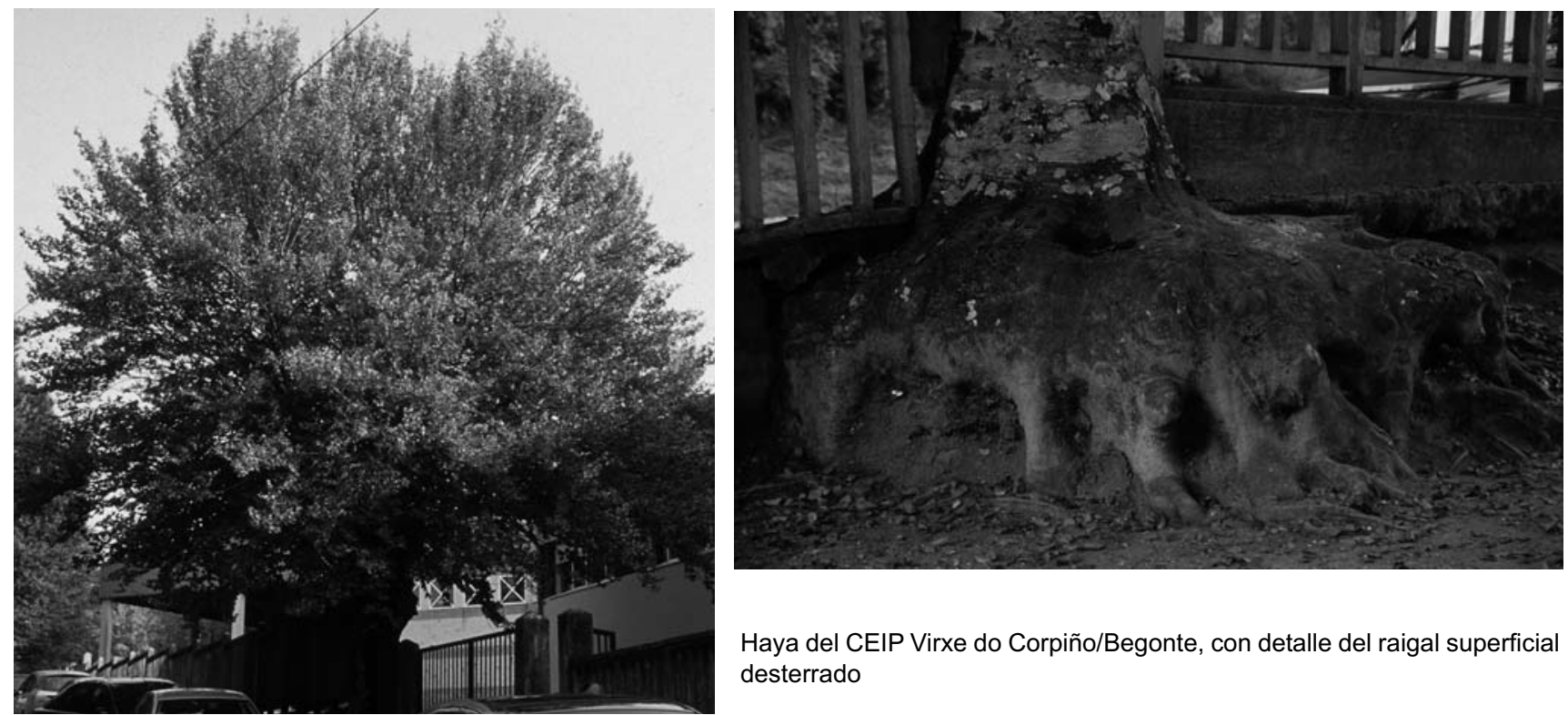

Haya del CEIP Virxe do Corpiño/Begonte, con detalle del raigal superficial desterrado protagonista sin discusión. La originalidad radica en el desterramiento al que fue sometido el árbol como consecuencia del rebaje terrenal practicado para crear el vial de acceso al centro escolar. De tal manera que, a juzgar por lo visto, el observador tiene ante sus ojos una mole de madera, formada por la expansión superficial del sistema radical y las raíces que en su día fueron subterráneas y ahora quedan al descubierto: en conjunto, asemeja a una mesa de madera con muchas patas.

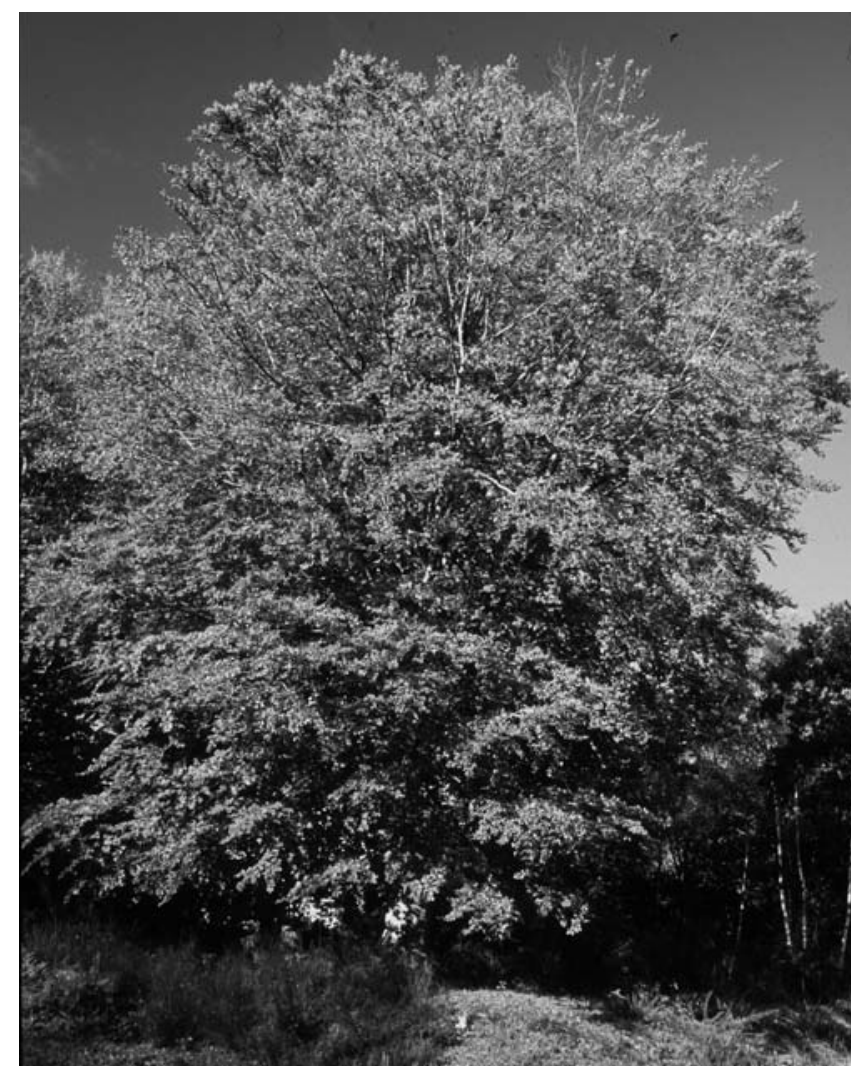

Haya del Bosquete das Modias/Begonte 


\section{Hayas del Parque Fluvial/Begonte}

Plantadas en pleno borde fluvial, integrando la hilera de árboles, intercaladas entre alisos y carballos, se localiza un trío de hayas memorables, que miran y se reflejan en el líquido elemento, hacia donde muestran su mejor cara. Aunque las tres tienen la misma antigüedad y responden a patrones fisionómicos con ciertas similitudes, hay diferencias entre ellas, por causas naturales y accidentales. De tal manera que el haya que está más distante de la presa y la zona de entrada al recinto es el pie mejor conservado, con dendrometría y tronco monopódico de mayor elevación, formando la cruz a media altura, desde donde se construye una copa aovado-globosa por descomposición en brazos y ramas en todas las direcciones.

De los otros dos ejemplares -con aceptable conservación, fustes cortos y horquillas bajas-, el primero forma muchos brazos, con uno que sube verticalmente hasta la cima y los demás abiertos en ángulo agudo, componiendo una copa de menor talla. El pie intermedio, de mayor altura, ha perdido uno de los brazos del tridente original, con afectación arquitectónica, aunque los otros dos, casi paralelos, por ramificación sucesiva han conseguido subsanar dicha carencia corporal.

\section{Hayas de la Alameda de la Plaza Mayor/Lugo}

En la placa metálica, incrustada sobre el tronco de uno de los árboles arrancados, se puede leer: "Esta alameda/foi creada en 1844./Por morte dos ulmeiros, fíxose/nova plantación/e reforma no ano 2003/Concellería de Medio Ambiente/Lugo, 25 de abril do 2003". Razones fitosanitarias motivaron la desaparición del arbolado existente pero ninguna causa justifica la pérdida del modelo tipológico de jardinería original, presente durante más de siglo y medio, hasta el punto de que, desde tal actuación, ya no se puede hablar de la histórica alameda, bien del Concello de Lugo, sita frente a la emblemática y monumental casa consistorial.

Tras esta sorprendente actuación, un cordón perimetral de hayas del tipo silvestre -plantadas en el invierno del 2002, procedentes de Viveros Arbor (Bruxelas/Bélgica), según información facilitada por Manuel Regueiro Sánchez-, de estilizadas figuras juveniles, que contabiliza nueve ejemplares orillando el cajón rectangular territorial, es todo lo que queda alrededor de una plaza cuya contemplación hace que se eche de menos la destrucción del primer jardín urbano público de la capital lucense. Como hecho anecdótico, la elección de la especie del nuevo plantel se hizo por consulta popular. El escenario del que forman parte y las causas de su aparición, le otorgan a la masa de hayas, desde el momento de su llegada, la connotación de flora memorable, aunque el éxito de la empresa no se conseguirá hasta que se recupere la estructura propia del jardín primitivo, hecha a base de salones arbolados, en los que el fagus es una especie de uso muy aconsejable, por formar parte de la flora autóctona provincial y disponer de excelentes cualidades ornamentales.

\section{Hayas del Parque de Rosalía de Castro/Lugo}

Uno de los activos principales del parque reside en la copiosa nómina de árboles del momento fundacional, en la década de 1920, al que pertenecen dos hayas del tipo silvestre de considerable porte -Haya del Parterre del Alcalde y Haya del Estanque de Patos-, a las que hacen referencia diversas publicaciones monográficas, entre otras, Rigueiro Rodríguez et al. (1995) y Rodríguez Dacal (1997a).

El Haya del Parterre del Alcalde, recinto centrado por el Monumento a Ángel López Pérez, yergue su tronco, de largo recorrido, hasta su bifurcación en la horquilla, en dos brazos gemelos, que se dirigen apretadamente hacia la cima. El árbol ajusta su copa al espacio disponible, mostrando un claro desequilibrio volumétrico hacia el paseo perimetral, donde crece con libertad y adquiere mayor desarrollo arquitectónico. El Haya del Parterre del Estanque de Patos -con el depósito acuoso, la pajarera y el Monolito a José Castiñeira Pardo como principales referentes construccionales- ha desarrollado un porte esbelto y altivo, de tipo columnar, obligada por razones de competencia espacial y búsqueda de luz.

Con anterioridad al proceso repoblador de la Alameda, en el año 2001, se procedió a la sustitución del arbolado del Paseo de los Olmos, utilizándose, en el tramo comprendido entre la Plazuela del Palco de la Música y la Entrada, según noticias de Manuel Regueiro Sánchez, hayas del tipo silvestre provinientes de Viveros Nilo/Tomiño. Quehacer que, hasta el momento, a tenor de lo visto, no obtuvo los resultados apetecidos, ya que sólo permanecen vivos un par de ejemplares juveniles, que padecen un acusado grado de sequedad y defoliación ramificacional.

\section{Hayas de la Casa de Cuiña/Guntín de Pallarés}

Remonta su fundación, la Casa de Cuiña, al año 1802, elemento principal de su preciado mundo arquitectónico. Ámbito en el que aparece el célebre Pino Marítimo de Cuiña, incluido en el catálogo arbóreo monumental (Rodríguez Dacal \& Izco, 2003). En palabras de la titular de la casa, Carmen Cienfuegos Jovellanos, las tres hayas fueron plantadas al mismo tiempo, en la década de 1940, por Mercedes López Pardo, debiéndose las diferencias existentes a la posición que ocupan, siendo el haya proximal, de mayor porte, el pie más cercano a la mansión residencial, en situación aislada, mientras que la pareja restante -haya intermedia y haya distal- posee menores cifras dendrométricas por la fuerte competencia espacial y lumínica que sufren en el bosquete y el pinar, respectivamente.

El haya proximal, a la entrada del bosquete, muestra una arquitectura regular y equilibrada, de bella factura, con copa amplia y muy ramosa, siendo llamativa la disposición que adoptan los dos brazos que salen de la cruz. El haya intermedia está al fondo del bosquete, encerrada por un trío de robles americanos que acotan triangularmente su espacio vital y menguan su figura. El haya distal vive en el pinar, abrazada por una orla de pinos jóvenes que debiesen de ser eliminados en beneficio del fagus.

Durante la visita, no hemos constatado la presencia de plántulas nacidas de la copiosa producción de hayucos, dato que nos confirma la dueña, apuntando que, de los escasos plantones germinados, sólo algunos consiguen transformarse en árboles viables, sin saber porqué desaparece el resto. 


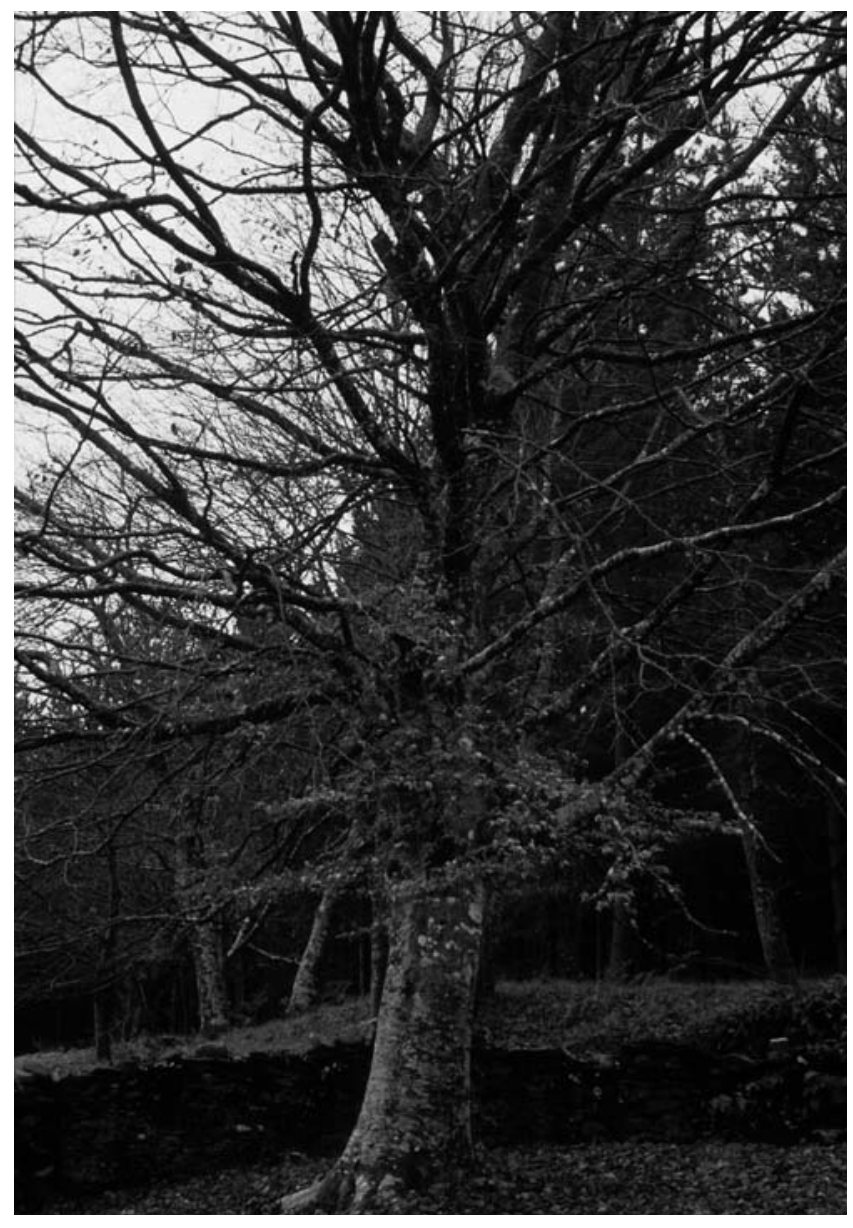

Haya de la Casa de Cuiña/Guntín de Pallarés

\section{Hayas del Pazo de Lusío/Samos}

Casi medio milenio tiene en su haber la Casa Grande de Lusío, propiedad de considerable superficie cuya casona, en el momento actual, atraviesa por un estado ruinoso del que pronto va a salir fruto de un convenio entre la Xunta de Galicia y el Monasterio de Samos, con miras a un nuevo cometido como albergue y museo. El ámbito más llamativo es su bosque de ribera, atravesado por un regato afluente del Río Sarria, cuyo valle alberga una masa forestal autóctona con importante participación de alisos, abedules, arces blancos, fresnos, carballos $y$, como elemento noticiable, una importante colección de fagus.

La población de hayas -difícil de cuantificar por el abandono que padece el bosque, que hace intransitable su recorridoconsta de árboles de distintas características corporales, repartidos diseminadamente por ambas laderas del valle, en mayor cantidad por la que colinda con la carretera. En opinión de los lugareños, asciende a varias docenas la nómina de pies de cierta entidad copal, que se incrementa en algunos efectivos más, de menor tamaño y edad, nacidos espontáneamente por germinación de hayucos, sin alcanzar el medio centenar el cómputo total, siendo generalizable la fuerte competencia que están sometidos.

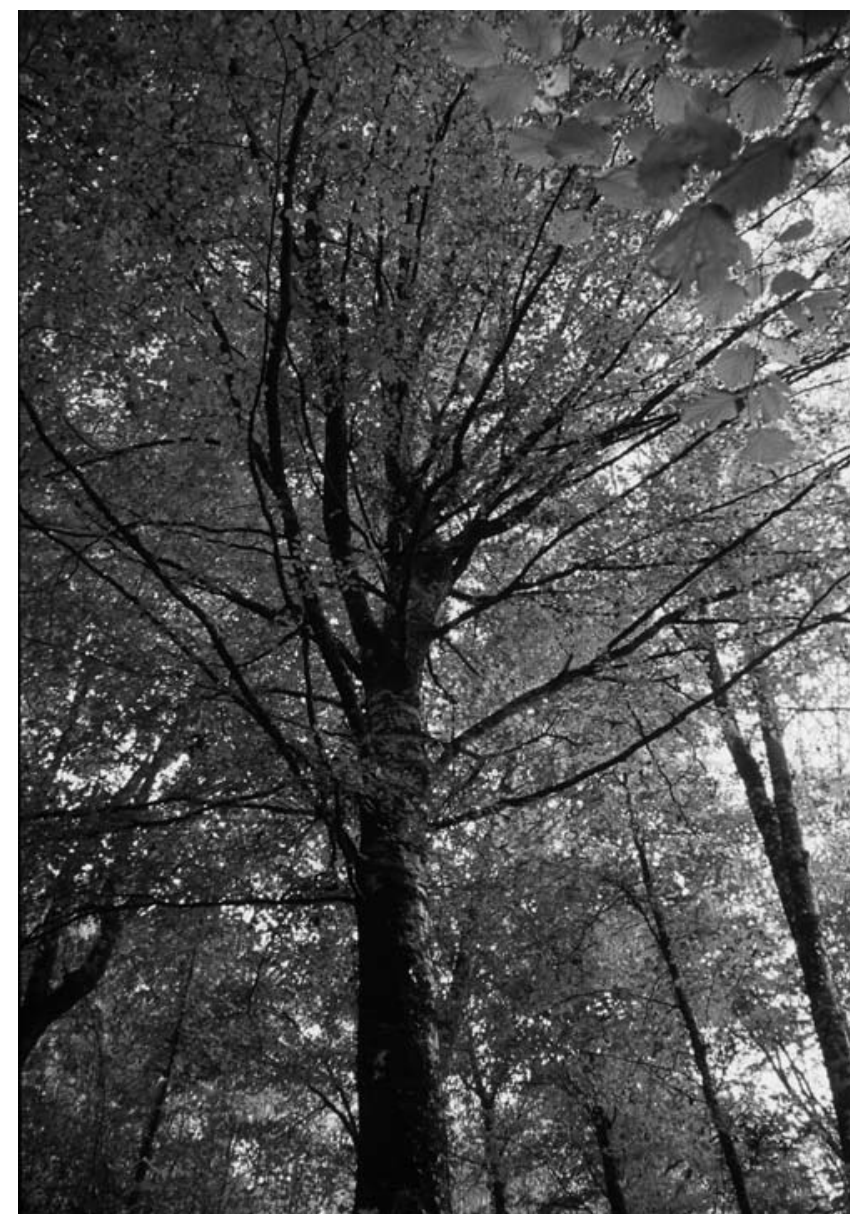

Haya del Pazo de Lusío/Samos

\section{Hayas del Santuario/Pedrafita do Cebreiro}

Se entiende, en el caso que nos ocupa, la importancia de los atributos ajenos, provinientes del lugar de asentamiento - artísticos (Santuario de Santa María la Real, hospedería, pallozas), histórico-culturales (Milagro del Santo Grial y Camino de Santiago, siendo Pedrafita uno de los puntos más carismáticos de la Ruta Francesa), paisajísticos (convergencia de las tierras altas de la Serra dos Ancares y la Serra do Caurel) y biológicos, escenificados por el mundo vegetal en todas sus manifestaciones, con el concurso de fagus entre sus formaciones boscosas y materiales de cultivo-, de cara a la puesta en valor del conjunto de hayas del tipo silvestre -media docena, en total, de diversas edades- presentes en tan señalado paraje, que potencian en gran medida sus méritos propios, emanados de la moderada antigüedad y la escasa entidad numérica del plantel.

En opinión de Luis López García, que regenta un establecimiento de hostelería en el poblado, los ejemplares añosos fueron plantados, hacia mediados de la década de 1970, por el cura-párroco, Elías Valiña Sampedro, al borde del muro delimitador de la entonces huerta de la casa rectoral -desde la década de 1980, se encespedó y actúa como campo de la fiesta-, componentes de una hilera 
arbolada con una configuración florística determinada, a base de abedul (especie dominante), arce blanco, haya, acebo y pino silvestre. Flora consonante con el ámbito montano, instalada sin orden ni concierto, no respetándose distancias mínimas entre árboles ni en relación al muro, por lo que ya se observan problemas de competencia espacial y de interacción física con la antiquísima y preciada cerca de piedra que enmarca tan señalado enclave.

\section{Hayas del Pazo de Fontao/Foz}

Constituyente del vasto mundo del Pazo de Fontao, en su católogo florístico, aparece el haya del tipo silvestre, dispuesta en alineación, orillando una de las márgenes de la pista general que sube desde la casona residencial hacia el Monte Rego Vello e Fontao, paralelamente al regato que nace en el monte y desemboca en el Río Ouro, con un marco de plantación en torno a $5 \mathrm{~m}$ de distancia. El titular del pazo y la Consellería de Agricultura, Pesca y Alimentación, suscribieron un convenio, de cesión terrenal para la práctica de una plantación arbolada multiespecífica, efectuada en distintos momentos, de la que forma parte el haya desde hace casi un par de décadas (17-18 años). Ha sido de gran ayuda, en la catalogación y documentación de este registro, la colaboración de Fermín Espiña Calo, agente forestal del distrito de la Mariña Lucense.

Aunque sus méritos propios no sean de especial relieve, hay que reseñar, como atributos ajenos, el hecho de su localización señorial, en uno de los establecimientos pacegos lucenses de renombre; su modo de estar, una hilera que agrupa tres docenas de pies, a los que hay que añadir otros individuos más jóvenes que se adentran en el curso del regato, bajo los castaños; y su vinculación a un convenio de repoblación forestal.

\section{Hayas de la Cantera de Sasdónigas/Mondoñedo}

Pareja de hayas de tipo silvestre, caracterizadas por sus soberbios portes y vistosas facturas corporales, que viven en la cantera de mármol de Lousada (parroquia de San Antonio y San Lorenzo de Sasdónigas), sitas en el valle del Rego do Carballo, afluente del Río Masma, en la ladera que mira al Sur, en posición de fondo, en un terreno de fuerte pendiente topográfica, compitiendo con la copiosa masa forestal por el espacio, la luz y el suelo. Los dos ejemplares presentan buen estado de conservación y exhiben características fisionómicas similares, con troncos monopódicos de considerable longitud, que crecen con derechura y verticalidad hacia lo alto y dibujan, por ramificación, imágenes aovado-globosas bastante estilizadas, con mermas volumétricas y desequilibrio del ramaje, más patente en uno de los árboles.

La diferencia dendrométrica del grosor troncal entre ambos, a priori, permite pensar en hayas de diferentes edades y suponer que la menor sea hija de la mayor, que es el haya superior, aunque no se descarta que correspondan al mismo momento introductorio. La información dada por Luis Rego Valcarce, alcalde de Mondoñedo, es de gran ayuda para la documentación histórico-cultural de dichas hayas. La cantera fue comprada por su bisabuelo, José Ramón Rego Villamil, entre 1900 y 1915, a los anteriores dueños, puesto que la empresa ya estaba en funcionamiento, manteniendo su actividad hasta mediados de la década de 1970. La dendrometría arbórea encaja bien en dicho periodo, de principios del siglo $\mathrm{XX}$, por lo que, a buen seguro, su llegada se produjo en tal época, siendo factible que exista alguna relación con este evento y que, incluso, el nuevo titular se encargase personalmente de su adquisición y colocación.

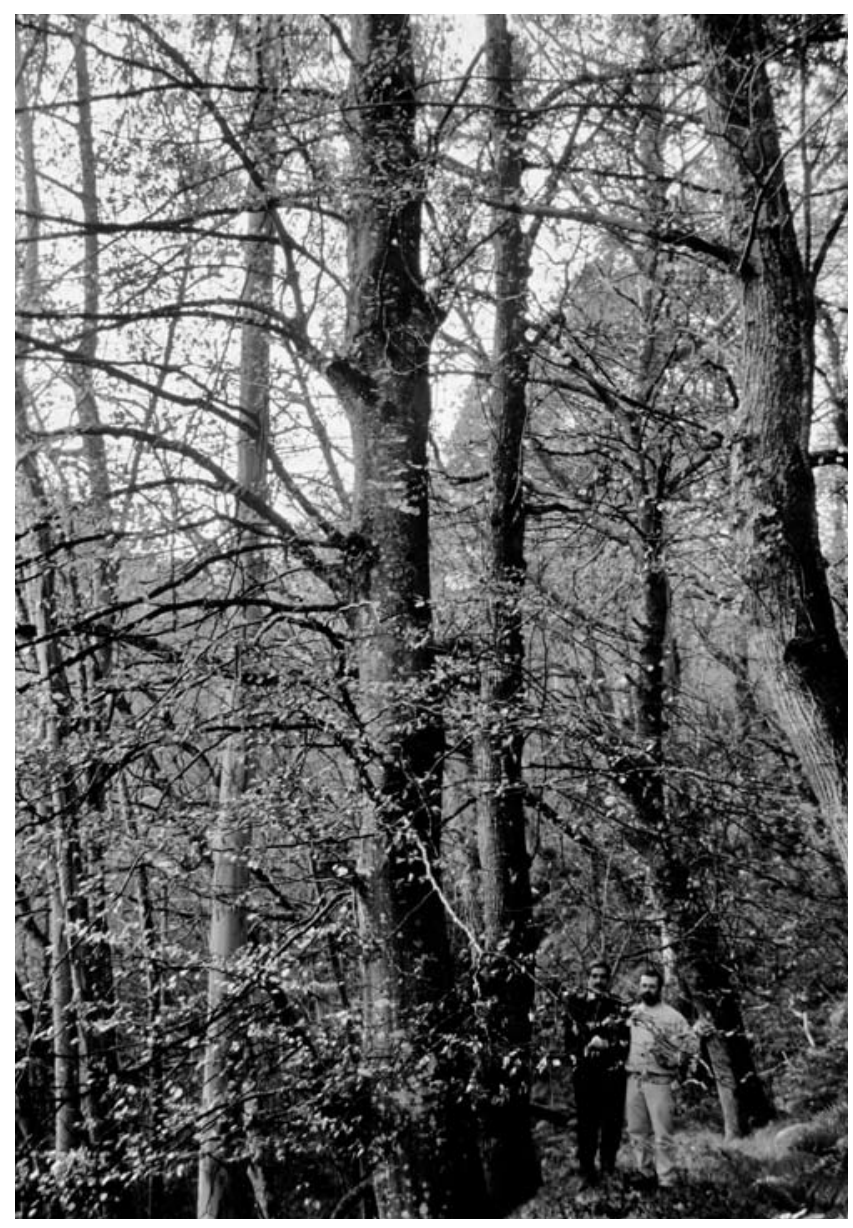

Haya de la Cantera de Sasdónigas/Mondoñedo

\section{Haya de la Finca dos Penedais/Ribadeo}

Reside en el lugar de Barreiros, parroquia de Santa María Magdalena de Cedofeita, en la orilla del Río Grande, que va a desembocar a la marisma de Ribadeo, por lo que su sistema radical está afectado por la proximidad y el contacto con el agua, en un terreno pendiente que mira al Noroeste, poblado con especies propias del bosque de ribera (alisos, sauces, saúcos) con importante masa de cultivo forestal (eucalipto). El haya ha sabido buscar su sitio y moldear su cuerpo con mucha suficiencia, a juzgar por su magnífica arquitectura, íntegra, saludable, bien organizada, de formato aovado-globoso, sobre un tronco corpulento, de contorno cilíndrico, poco elevado, que emite brazos y ramas desde la horquilla, en todas las direcciones, responsables de la figura copal. Su conservación es óptima, sin incidencias negativas. 


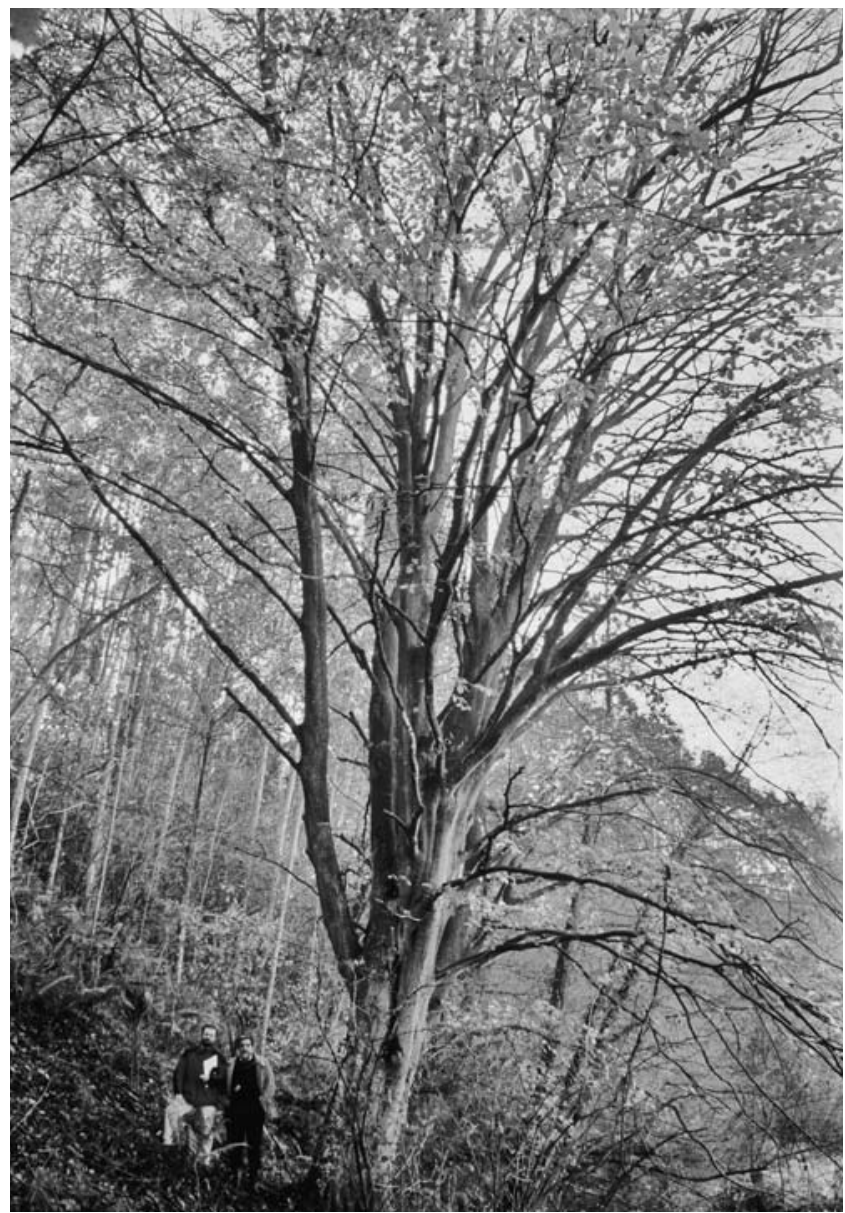

Haya de la Finca dos Penedais/Ribadeo

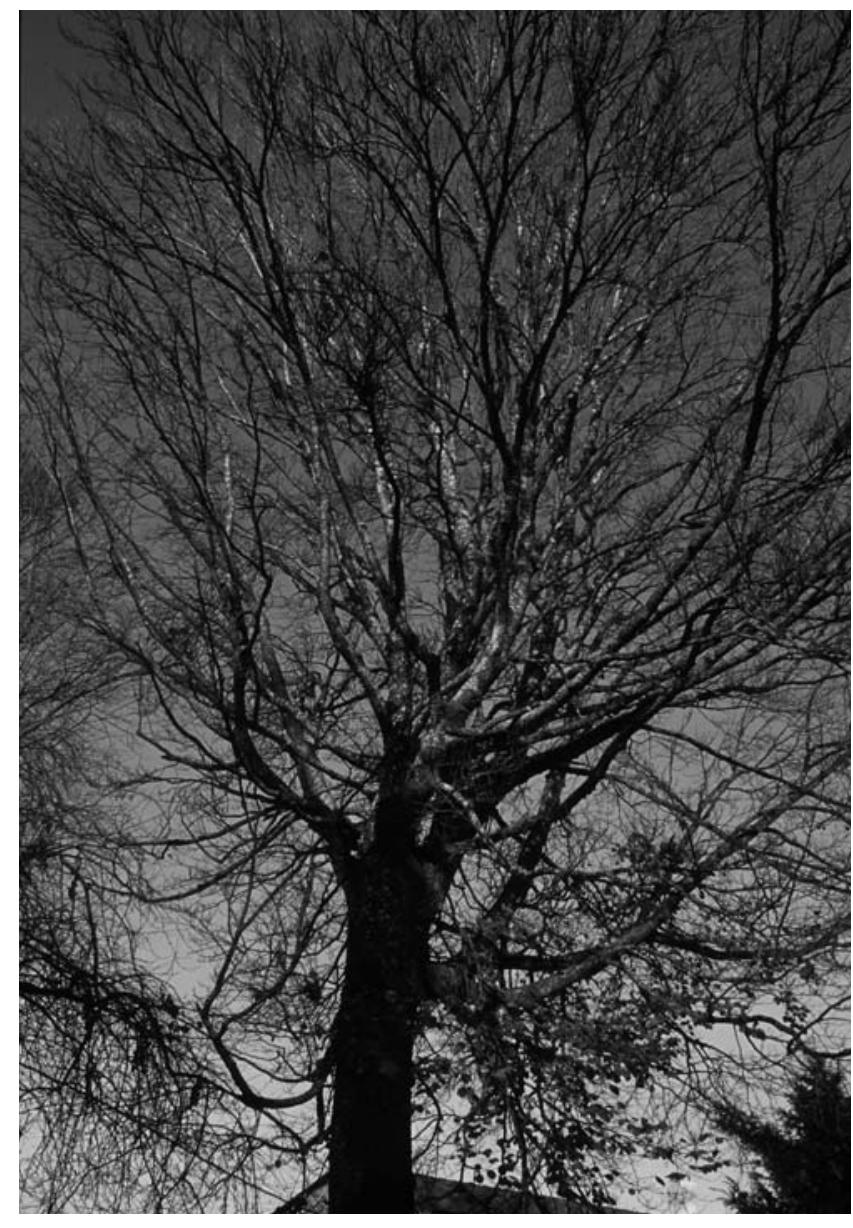

Haya de la Casa de Cosme/Pol
En plan cultural, interesa significar la abundante cosecha de hayucos, de los que nacen pocas plántulas, contando con algunos hijos legítimos en el pueblo y en otras partes. A decir de $M^{a}$. Encarnación Fernández Yáñez, propietaria de la finca, el haya la plantó su tío y padrino, José Fernández Yáñez, fallecido en 1969 ya nonagenario. La edad supera los tres cuartos de siglo, camino de la centena, sin poder precisar el momento de la llegada al lugar que ocupa. No debemos pasar por alto la presencia del Pazo de Cedofeita, próximo a la finca, por razones artísticas y simbólicas, ya que tío y sobrina fueron caseros de la noble posesión señorial.

\section{Haya de la Casa de Cosme/Pol}

Delia Díaz Vila, dueña de la Casa de Cosme, en la parroquia de San Cosme de Gondel, guarda con celo el haya del tipo silvestre plantada por su abuelo, José Díaz Abraira, hacia mediados de la década de 1920. No oculta sus temores de que un día pueda caer sobre la casa familiar, circunstancia de fácil solución sin su presencia, aunque pueden más el cariño y el sentimiento. La Fraga da Marronda/Baleira fue la fuente provisoria de un par de ejemplares, uno instalado delante de la casa y otro en una finca, lamentablemente desaparecido.
Se trata de un pie que deja ver un raigal superficial del que arranca un tronco monopódico hasta la cruz, medio-baja. Libre de competencia, la ramificación es amplia y profusa, configurando la arquitectura aovado-globosa típica de la especie. Buen estado de conservación, sin incidencias dignas de reseña, salvedad hecha de algunas setas en la zona basal, a la altura del raigal superficial, que está descubierto y manifiesta desgaste producido por tránsito circulatorio, de vehículos y gentes.

Debe la condición memorable que se le otorga a méritos intrínsecos, fundamentalmente de tipo biométrico, tanto dendrométrico, con una veintena de metros de talla y un par de metros de cuerda troncal, como de edad, que supera 75 años. El asentamiento geográfico ayuda poco, teniendo en la iglesia parroquial el único argumento reseñable. EI capítulo cultural se centra en un par de hechos: el conocimiento de la identidad del plantador y la abundante germinación de semillas, con retoños que vienen a buscar gentes para plantar en sus fincas.

\section{Haya de la Casa da Abureira/A Pontenova}

A la salida del pueblo de Recesende, en dirección hacia Riotorto, desplazándose por la carretera, está la Casa da Abureira, con su bosquete ornamental y su haya de tipo 
silvestre, emplazada en el valle del Río Torto, en posición de media ladera, en un territorio de fuerte pendiente que cae naturalmente hasta el cauce fluvial.

El bosquete ornamental, por la composición florística, se puede calificar como "bosquete de coníferas", ya que buena parte del arbolado está copado por esta clase de árboles (ciprés de Portugal, tuya gigante, cedro del Atlas, camecíparis de Lawson, douglasia verde, criptomeria, abetos), con presencia de especies planifolias e inclusión del haya. El artífice y responsable de la plantación es Atilano Novo Lodos, anterior titular, ya fallecido, amigo de los árboles, en la década de 1960.

El haya se localiza en el extremo próximal a la carretera, con un campo de visualización reducido por la competencia con la masa de coníferas, saliendo mal parada de dicha situación. Por tal circunstancia, su porte es elevado, en busca de luz, pero irregular y desgarbado, arrancando de un tronco corto formador de una cruz de brazos ascendentes y apretados, que sacan ramas para hacerse sitio, destacando por su formato modificado y lleno de oquedades.

\section{Hayas del Parque Municipal/O Carballiño}

La enormidad territorial, la condición de parque fluvial y la flora que alberga, encabezada por masas de pinos y de tilos, son atractivos determinantes para la evaluación del parque carballinés. Argumentos que motivan la inclusión de las hayas purpúreas juveniles dentro del colectivo memorable, pesando más en la decisión los atributos extrínsecos que los méritos intrínsecos. La proximidad plantacional de la media docena de pies componentes de la alineación, obliga a la compartición del espacio copal individual, que ya comienza a producirse a los pocos años de vida. Son árboles de características parecidas, con troncos definidos, de baja altura, y cruces que emiten brazos y ramas constructores de una arquitectura aovadoredondeada.

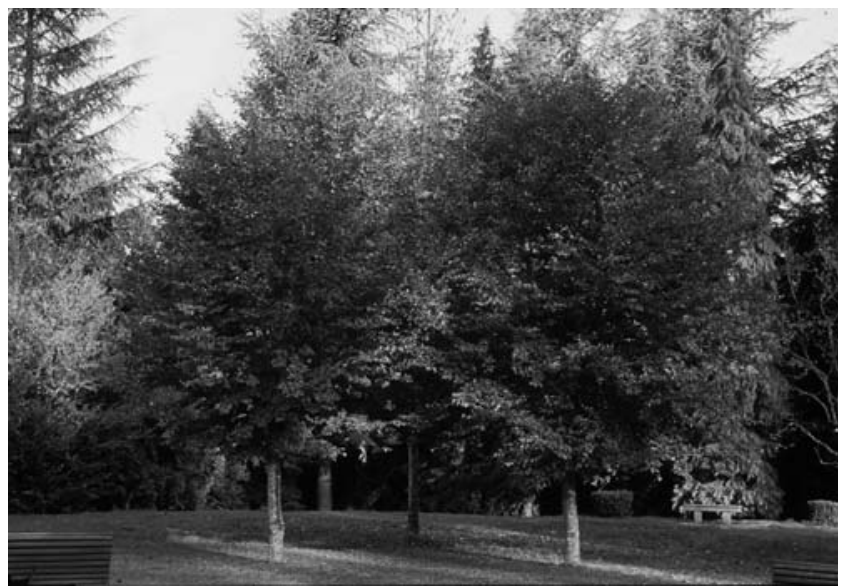

Hayas del Parque Municipal/O Carballiño

Forman parte de un emplazamiento privilegiado, no en vano se localizan en la plaza de entrada, presidida por un monumento en memoria de los Hermanos Prieto, que corona la isleta del estanque. A su alrededor se extiende una pradera orlada por doble cinturón arbolado: el interno, repartido entre camelias y hayas purpúreas, y el externo, de tuliperos virginianos. Aunque las camelias son más numerosas que las hayas, no pueden competir, hasta el momento, con su protagonismo, por razones de volumetría y vistosidad, a pesar de las dos bajas del octeto inicial, por sequedad. La pantalla del bosquete de coníferas, al fondo, pone un marco de elegancia y un toque de distinción insuperables.

\section{Haya de la Fervenza do Muíño/Celanova}

Un proyecto de recuperación de la Corga do Sampil, afluente del Río Ourille, a su vez afluente del Río Arnoia llevado a cabo por el IES de Celanova en el curso escolar 1999-2000, planteado como una actividad medioambiental de carácter interdisciplinar-, permitió el descubrimiento de un interesante ejemplar de haya de tipo silvestre, en un punto señalado del cauce fluvial, la Fervenza do Muíño, a medio kilómetro del Monasterio de San Salvador, al borde del camino que conduce al lugar de O Cercado.

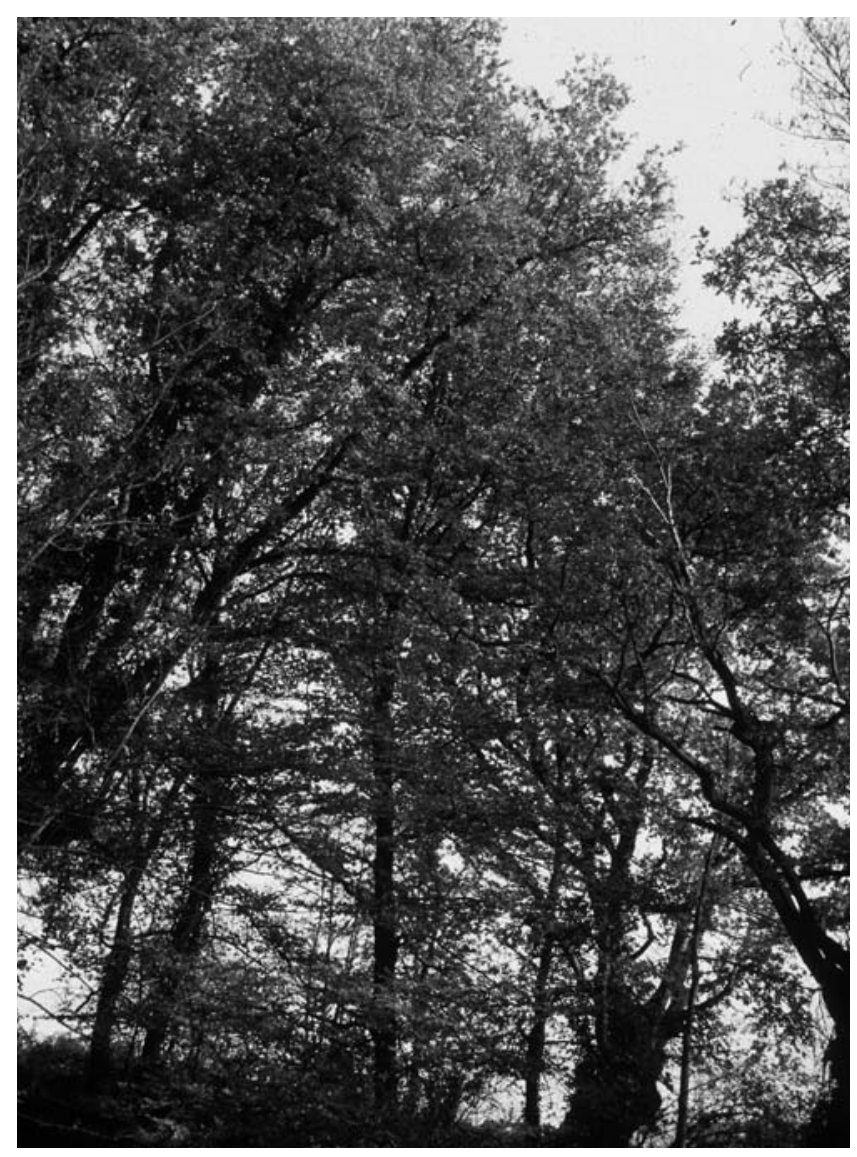

Haya de la Fervenza do Muíño/Celanova

En un entorno de bosque de ribera dominado por el aliso, en vecindad a carballos seculares, contrasta la presencia del haya, como árbol de porte estilizado, ampliamente columnar, con volumetría copal condicionada por las poderosas arquitecturas de los quercus, aunque el fagus se ha ganado a pulso su habitáculo, mostrando una querencia 
expansiva copal hacia la zona del camino y del puente, donde está libre de competencia. A pesar de la abundante cosecha frutal, no se constata la presencia de ninguna plántula germinada.

Vista la edad del haya -tomando en consideración la información facilitada por Elisa Mercedes Seara Cid, profesora del centro celanovés, que recabó datos sobre la propiedad de la parcela-, es factible que su aparición y plantación en el sitio residencial pueda guardar relación con el anterior titular de la finca, Luis Iglesias Iglesias, Catedrático de Biología y Director del Museo de Historia Natural "Luis Iglesias"/Santiago de Compostela.

\section{Haya del Balneario de Cabreiroá/Verín}

Ocupa posición céntrica en el Bosque de los Abedules, parcela del parque comprendida entre el hotel-balneario y el Río Abedes, en un entorno dominado por árboles de diferente porte y edad. En relación a su llegada al recinto, en opinión de Elisardo Domínguez Martínez, director de fábrica, se produjo hacia mediados de la década de 1990, en forma de plantón con un par de metros de talla, aproximadamente, procedente de viveros leoneses (Ponferrada). A pesar de su juventud, ya está sometida a competencia espacial y lumínica. Hasta el momento, los efectos son mínimos, por lo que su fisionomía no muestra incidencias corporales, siendo lo más noticiable la falta de campo visual.

El haya destaca más por las excelencias del lugar de asentamiento -uno de los establecimientos termales más señeros de Galicia, por la envergadura de su mundo arquitectónico (encabezada por el hotel-balneario y el templete de las aguas) y la entidad del parque-jardín, llamando la atención su extensión y la abundancia de coníferas- que por los méritos propios, por tratarse de un pie de pocos años que sólo tiene a su favor la buena configuración y conservación.

\section{Hayas de la Serra da Enciña da Lastra/Rubiá}

La información proporcionada por el responsable de su introducción, Juan Higueras de Marco, Jefe del Servicio de Montes de Ourense, enriquece el acervo histórico-cultural de esta masa forestal. Con semilla procedente de Navarra, se produjeron plántulas en el Vivero Río Farelos/Vilamartín de Valdeorras, dependiente de la Consellería de Agricultura, Gandería e Montes, instalándose 40 plantones con cepellón, de dos años de edad, en febrero de 1978, en la zona más idónea del parque natural, seleccionada por su orientación, buscando las condiciones más umbrófilas, y pH terrenal, próximo a la neutralidad. Se practicaron labores previas de desbroce y preparación del suelo, abriéndose hoyos de $40 \mathrm{~cm} \times 40 \mathrm{~cm} \times 40 \mathrm{~cm}$. Al cabo de dos años, se hizo un seguimiento y se constataron 17 fallos. En 1985, se efectuó una reposición (60 ejemplares), provinientes de semillas de Navarra germinadas en el Vivero Río Farelos. La razón que motivó la plantación fue la repoblación de una zona incendiada de pinar (Pinus sylvestris) en el verano de 1977, formando parte de foresta actual.

La colaboración de Javier Blanco, agente forestal del distrito, facilitó la localización y el acceso de las hayas del tipo silvestre, en el paraje conocido como Caprada, en la cara norte de la Serra Malvela, coronada por los celebérrimos Penedos de Oulego. Terreno de fuerte pendiente, donde vegeta, en posición de fondo y en las cercanías de un regato, el plantío de hayas, integrante de una masa arbolada multiespecífica. La nómina contabilizada, de modo aproximado, ronda el medio centenar de pies, aunque suponemos que el total real supera en algunos efectivos la cantidad indicada. Para la edad que tienen, sorprende el buen grado de desarrollo volumétrico y la talla de los portes individuales, que adoptan patrones corporales aovado-redondeados, favorecidos por las condiciones edáficas.

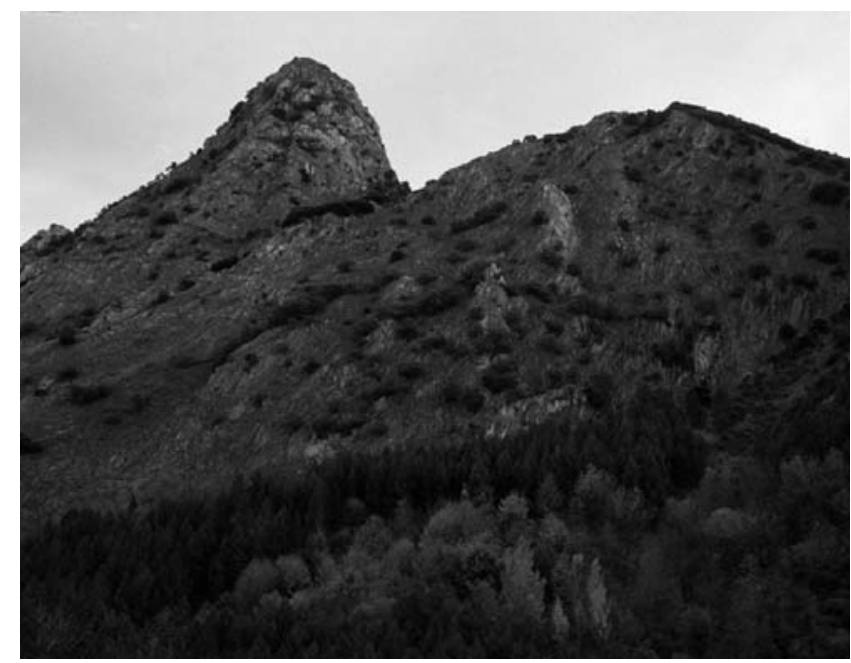

Hayas de la Serra da Enciña da Lastra/Rubiá

\section{Hayas de la Serra do Xurés/Lobios}

En compañía de Andrés Gea Martínez y Jesús Martínez Garrido, agentes forestales del distrito, llegamos hasta el enclave posicional de las hayas de tipo silvestre, en la ladera Norte del valle fluvial de la Corga de Calvos, afluente del Río Caldo, relieve topográfico de acusada pendiente cubierto naturalmente por un bosque de melojos y de carballos, con otras especies intercaladas. La población de hayas -su número de ejemplares, no determinado con exactitud por dificultades técnicas, supera la centena, constituyendo, entre el material conocido, la masa cultivada más copiosa de Galicia-, según información proporcionada por Ermindo Ferreira Martínez, capataz forestal jubilado, corresponde, en origen, a una plantación practicada hace medio siglo, aproximadamente, por técnicos del Centro Forestal de Lourizán/Pontevedra.

Las hayas -citadas en la guía florística del parque natural (Pulgar Sañudo, 2005)- se encuentran intercaladas en el bosque autóctono, ocupando considerable extensión, que supera la media docena de hectáreas. El arbolado, de distintas edades, bien conservado, se adapta a las condiciones ambientales del entorno, en un tramo altitudinal comprendido entre $650-800 \mathrm{~m}$, proyectando portes estirados hacia lo alto, por razones de competencia espacial y lumínica, con troncos y cruces de distinta hechura y elevación. 


\section{Haya del Pazo de Vista Alegre/Vilagarcía}

En el bosquete del fondo, antesala del mirador portuario, una fenomenal haya del tipo silvestre, valiéndose de su carácter umbrófilo, ha desarrollado una arquitectura copal de mucha volumetría, con silueta aovado-redondeada, sintiéndose a sus anchas en un entorno donde el arbolado acompañante, representado por ejemplares añosos, compite por el espacio y la luz, saliendo victoriosa el haya, que consigue buena parte del espacio disponible. El tronco -anclado en el terruño mediante un potente raigal, que deja ver su estructura y disposición superficial- tarda en perder su monopodismo, mostrándose como un eje cilíndrico, derecho y vertical, bien conservado, estado físico y saludable extensible a toda la masa corporal.

Mírese como se mire, el del Pazo de Vista Alegre es uno de los registros más señalados del haya como especie de ornato en nuestra tierra: por valores intrínsecos -centrados en su dendrometría, antigüedad y fitosanidad- $y$ extrínsecos, que proceden del marco pacego y la condición de colegio, que supone la puesta en contacto diaria de la comunidad educativa con la foresta de la finca. Se trata de un ejemplar familiar y popular, a nivel local, que, a través de esta publicación, mejorará su cuota de conocimiento y difusión -aparece citado en la tesis doctoral de Rodríguez Dacal (1990)- en los lares gallegos y allende fronteras.

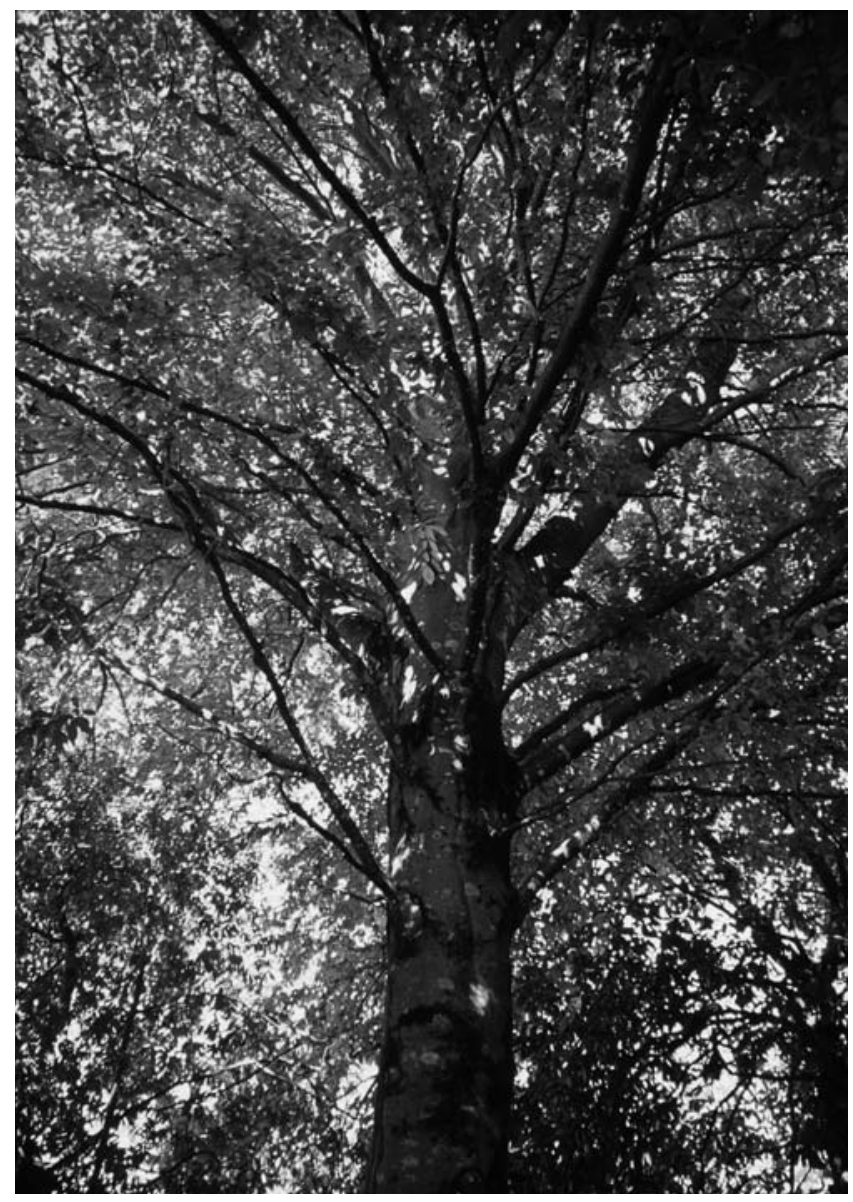

Haya del Pazo de Vista Alegre/Vilagarcía de Arousa

\section{Haya del Parque-Jardín/Caldas de Reis}

Vive abrazada a una añosa cunninghamia, una de las joyas florísticas del establecimiento caldense, en un entorno vegetacional presidido por el agobio emanado de la arboleda enmarcante, mostrando la mejor cara en la plazuela de la fuente, hacia la que mira, atravesada por el tronco monopódico de la conífera, cuya elevada disposición copal no perjudica a la fagácea. En realidad, la notoriedad del ejemplar se debe más al marco de asentamiento -no en vano reside en uno de los jardines de mayor entidad de Galicia, declarado paraje pintoresco desde el año 1962- que a sus méritos propios, por tratarse de un pie juvenil. En su favor, juega también la apoyatura bibliográfica de que dispone, por figurar en algunas publicaciones monográficas (Rodríguez Dacal, 1997b y 1999) sobre el histórico jardín.

A pesar de las limitaciones ambientales, el haya ha ganado su sitio sin mucho esfuerzo, aunque a corto plazo será cuando aparezcan los problemas, que ya se atisban ahora, porque el ramaje copal entrará en confrontación con la foresta vecinal, con las consiguientes repercusiones negativas para todos los partícipes. A pie de árbol, aparece un rótulo botánico, sobre soporte granítico, con información florística y distribucional.

\section{Hayas del Pazo de Lourizán/Pontevedra}

Dispone, el Pazo de Lourizán -cuya vasta finca, superior al medio centenar de hectáreas, por derecho propio, se convierte en uno de los principales referentes del cultivo de hayas-, de interesantes publicaciones (Rodríguez Dacal, 1990; Rodríguez Dacal \& Izco, 1994; Fernández de Ana Magán \& Álvarez Fernández, 1994; Blanco-Dios, 2005) para su conocimiento histórico, artístico, cultural y botánico. Aquí conviven un trío de viejos fagus, que superan el medio centenar de años, en una de las parcelas de eucaliptos del monte, cerca del Parque de las Rías; una plantación reciente, que se cifra en unos setenta ejemplares, en la zona de entrada original; una pequeña muestra, de probado valor simbólico; y un vistoso pie de haya purpúrea, entre el edificio principal y el invernadero.

La ayuda inestimable de Francisco Javier Silva-Pando y de Francisco J. Fernández de Ana Magán facilita en extremo la reseña de la plantación de hayas practicada en el año 1992, en la entrada original de la posesión, con un cómputo aproximado de 70 pies, a base de plantones de un par de años germinados en los viveros del pazo, a partir de semillas procedentes de poblaciones naturales del Norte de España, incluyendo las gallegas. Así como la representación de hayas -provinientes de escenarios naturales de Navarra y Cantabria, desde donde llegaron individuos con edades comprendidas entre 5-10 años- que figura en el Parque de las Autonomías (jardín que cuenta con una colección de las especies arbóreas más características de la mayoría de las comunidades autónomas españolas), creado en 1993, con motivo de la celebración del I Congreso Forestal Español-Lourizán 1993.

En relación al trío de hayas añosas, inmersas en el eucaliptal de la finca, decir que, en general, muestran buena conservación; presentan soldaduras, por injertos de aproximación, en brazos y ramas; y se constata una 
abundante producción de hayucos y muchos plantones generados por germinación, que viven al lado de sus progenitores, con diferentes edades y tallas.

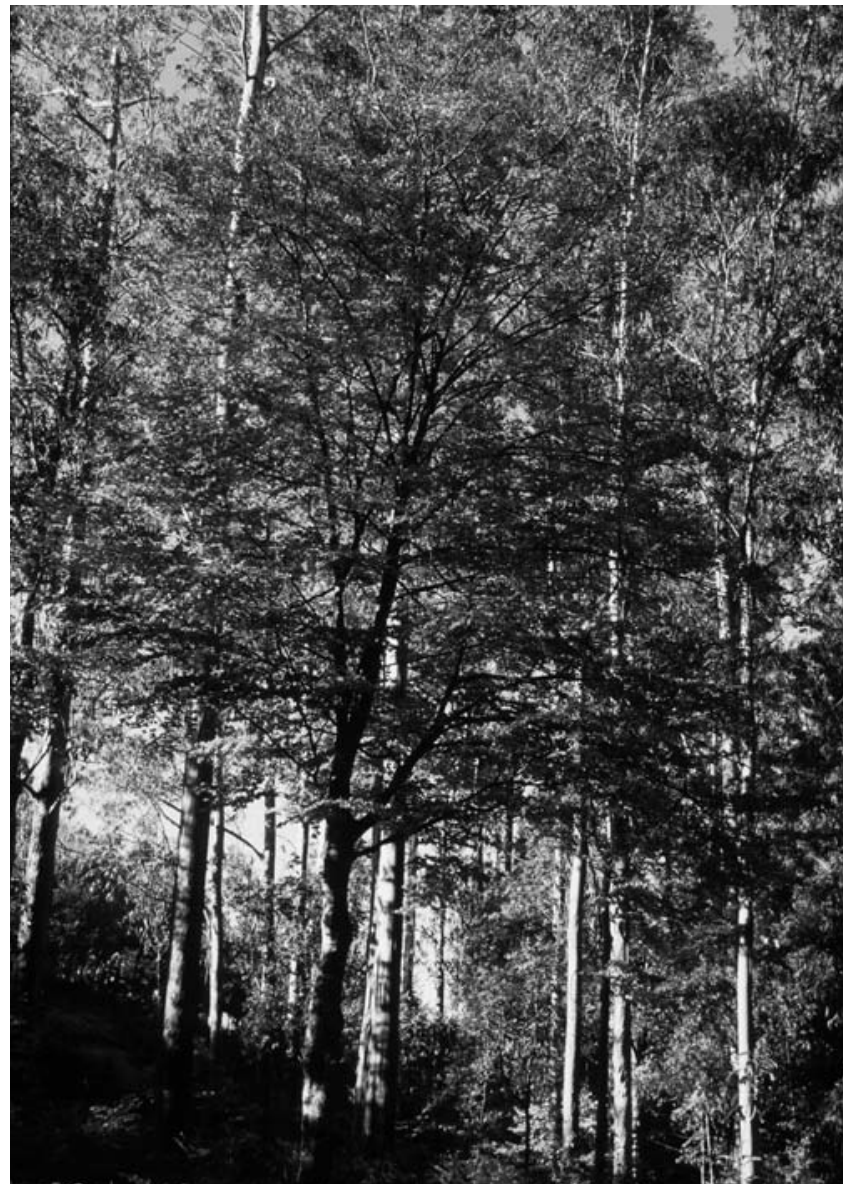

Haya del Pazo de Lourizán/Pontevedra

\section{Haya Purpúrea de la UNED/Pontevedra}

Rafael Areses (1953), en su libro sobre parques y jardines pontevedreses, nombra el Haya de la Granja de Monteporreiro, perteneciente a los herederos de Casimiro Gómez. Reseña histórica que nos informa acerca de los orígenes de esta significada propiedad, cuyo solar contiene, desde hace algunas décadas, el Centro Regional de la Universidad Nacional de Educación a Distancia (UNED).

Van de la mano juntas, en muchas ocasiones, en buena sintonía, arquitectura y naturaleza. En el caso de la asociación haya-UNED, la vecindad es tan próxima que resulta molesta para ambos partícipes. Saliendo perdedor el árbol, que ha visto mutilado parte de su potencial corporal en aras de la ciencia. La abundante presencia de tronzamientos y cicatrices constata inequívocamente el daño provocado. Pero es mucho lo que queda, tanto que produce la admiración del espectador -cuando la encuentra, empresa no fácil a primera vista por estar en cierto modo escondida y aislada de la arboleda del parque-, por disfrute del fuste, corto pero poderoso, que se ensancha y divide en la cruz, formada por dos brazos que se proyectan hacia arriba en ángulo agudo y se van ramificando abiertamente en todas las direcciones proyectando una imagen copal aovado-redondeada. El individuo luce una figura espléndida, a pesar de las pérdidas, integrando el elenco de hayas más preciadas del país.

\section{Haya Purpúrea Pazo de Torrecedeira/Redondela}

Corresponde a la creación jardinística original, practicada en la década de 1860 por orden de Manuel Bárcena y Franco, la plantación del haya purpúrea, en pleno corazón del parque. Establecimiento que aporta cuatro registros (calocedro de California, cedro del Himalaya, haya purpúrea y liquidámbares) al catálogo arbóreo monumental (Rodríguez Dacal \& Izco, 2003). Todo llama la atención en este árbol sin parangón, reseñado con otro fagus acompañante por Rodríguez Dacal (1990), que constata su germinación como expresión de adaptación al escenario de cultivo.

Es indiscutible su veteranía, por tratarse del ejemplar de mayor edad entre los de su clase que vegetan cultivados en Galicia, camino del siglo y medio de antigüedad. El porte acredita valores punteros en talla, superior a la treintena de metros, y en volumetría, figurando en el grupo de cabeza por su enorme amplitud. El tronco, de gran envergadura y majestuosidad, asentado sobre poderoso sistema radical que enseña sus arranques antes de hundirse, crece con derechura y verticalidad, monopolizando su protagonismo hasta la cima, a pesar de ramificar pronto. La verdadera cruz la forma a 10,50 m, apreciándose soldadura previa, por injerto de contacto durante un trecho, de los dos brazos componentes, antes de su total separación. A pesar de la significada elevación, interesa más su perimetría, que supera $4 \mathrm{~m}$ de circunferencia, cifra que la convierte, entre el material conocido e inventariado, en el haya viva cultivada del Fogar de Breogán con fuste de mayor grosor.

Con tantos años en su haber, sorprende su buen estado de conservación, sin problemas importantes. A resultas de lo dicho, la significada volumetría copal incrementa al máximo la frondosidad y la umbrosidad que exhibe, manteniéndose vigente todo el potencial de ornato, que gana enteros por el follaje purpúreo, en claro contraste con el verdor del entorno vital. El único "pero" procede del campo visual, reducido a mínimos por la agobiante vegetación del parque.

\section{Hayas del Pazo de Castrelos/Vigo}

En el Parque de Castrelos, se localiza media docena de hayas memorables, 2 del tipo silvestre y 4 purpúreas, de gran espectacularidad y vistosidad, incluidas en el patrimonio arbóreo monumental (Rodríguez Dacal \& Izco, 2003), introducidas en el último cuarto del siglo XIX con motivo de la creación del recinto ajardinado. Fernández Alonso \& Rigueiro Rodríguez (2001), en el catálogo de árboles singulares vigueses, contabilizan 9 pies. Algunas de estas fagáceas se citan y miden en otras publicaciones (Rodríguez Dacal \& Izco, 1994; Leiro Lois et al., 2006). A pesar de su condición secular y de la competencia ambiental, el colectivo muestra una conservación aceptable. Aunque las cosechas de hayucos son abundantes y nacen plántulas por germinación espontánea, la mayoría de los individuos juveniles del tipo silvestre que aparecen en el escenario pacego son de procedencia foránea. 


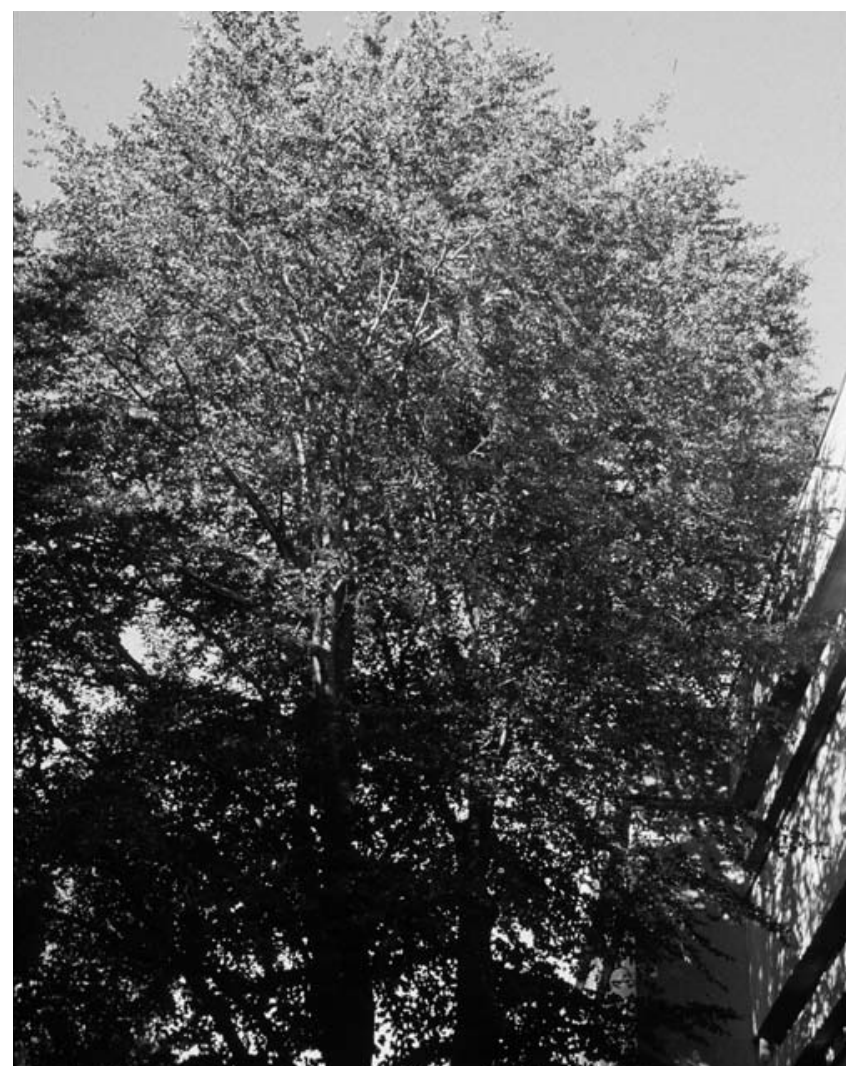

Haya Purpúrea de la UNED/Pontevedra

La pareja de hayas del tipo silvestre -recogida en el Catálogo Galego de Árbores Senlleiras (Diario Oficial de Galicia, 2007)-, próximas al auditorio musical, son árboles con arquitecturas de similares características: sobre corpulentos ejes troncales cilíndricos, de llamativa corteza lisa y grisácea, provistos de imponentes raigales basales estabilizadores, se forman, a igual elevación, sendas horquillas, con brazos que ascienden en la vertical y construyen amplias copas por abundante ramificación, compartiendo su espacio vital por razones de vecindad. Su aspecto es espléndido, sobre todo en su "cara buena", por ausencia de vegetación, que permite su contemplación y disfrute al observador.

El cuarteto de hayas purpúreas, bien conservado, está más próximo al palacio, separado por potente muro pétreo. El trío más cercano a la muralla angular compone una alineación: uno con inconfundible formato en tridente, por la descomposición basal del fuste en tres brazos; en los dos restantes prevalece el monopodismo, a pesar de las ramas generadas en su recorrido, no pudiéndose hablar de verdaderas horquillas hasta zonas altas. El cuarto pie, al borde de la carretera, destaca por la bella arquitectura fisionómica, adoptando la base del ramaje una disposición arqueado-descendente que casi toca el suelo y configura un singular y atractivo techo cupuliforme.

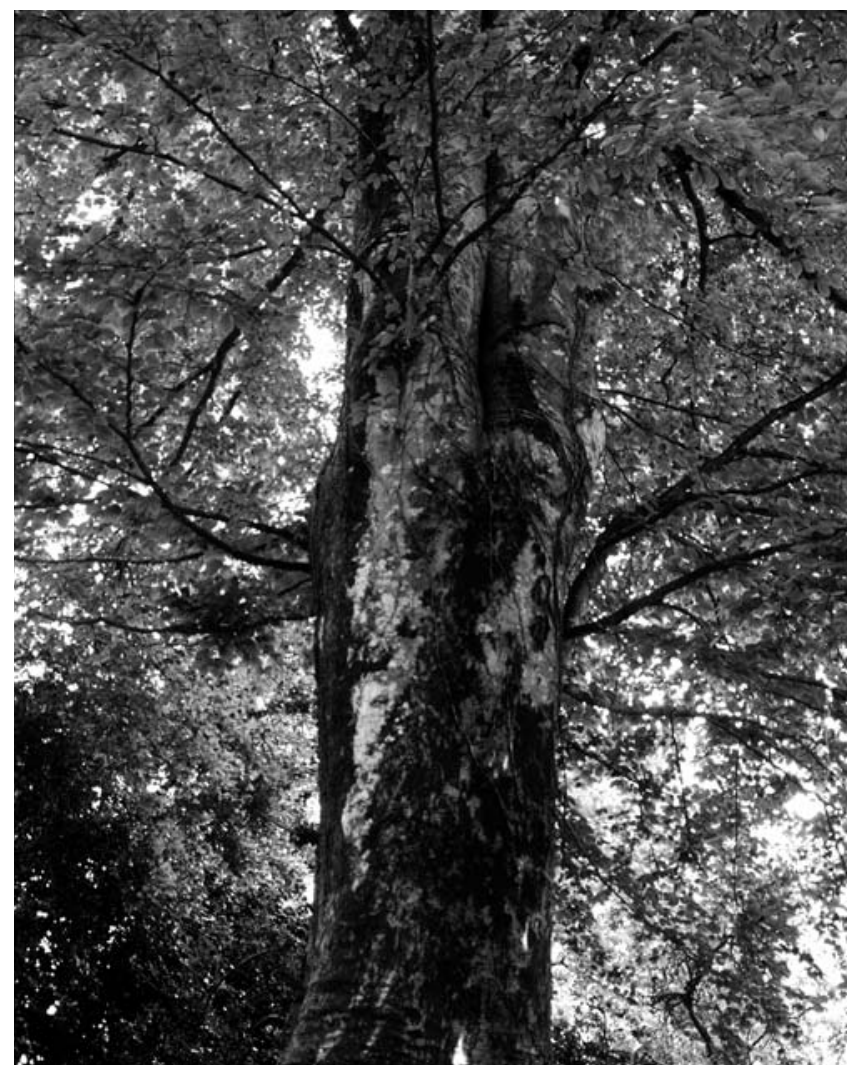

Haya Purpúrea del Pazo de Torrecedeira/Redondela

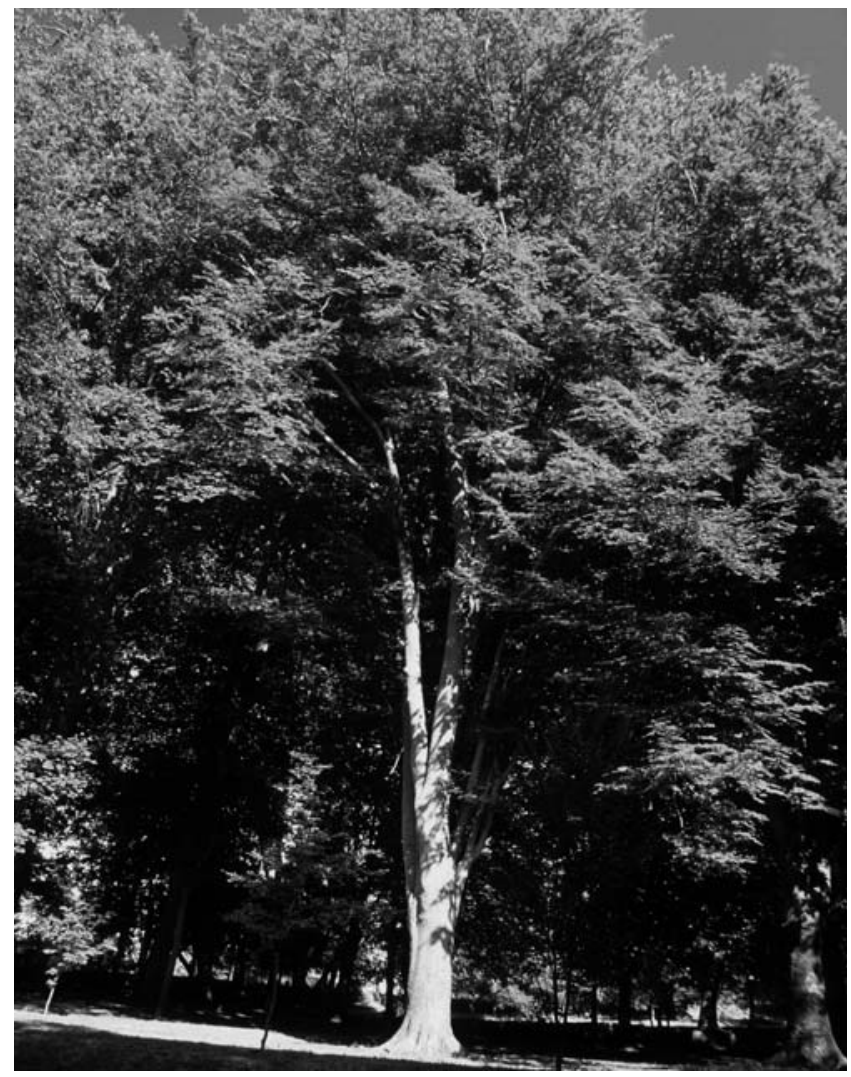

Haya (tipo silvestre) del Pazo de Castrelos/Vigo 


\section{Hayas del Castillo de Monte Real/Baiona}

En la cima de la fortaleza, está el pinar, con suelo forrado de pradera, formación multiespecífica dual, forestal y ornamental, que recibe tal denominación por el predominio del pino insigne sobre los demás árboles, con aparición del haya entre las especies caducifolias. A la hora de la selección de este registro, todo el peso recae en el magnífico escenario artístico -que emana del mundo constructivo atesorado por la carismática fortaleza gallega, sin parangón e insuperable, que dispone en el monte su muralla, el paseo de ronda y la Casa de Pedro Madruga- y paisajístico, por el enclave geográfico y la masa verde intramuros.

La población de hayas -que cuenta con siete individuos del tipo silvestre, en línea contra el muro separador de la huerta-, malvive por falta de planificación en origen, formando parte de un plantel de filas arboladas puesto sin orden ni concierto, criticable por todos los conceptos, tanto por la mezcolanza florística utilizada como por el insuficiente marco de plantación, que condena físicamente a la arboleda de adorno, padeciendo sus efectivos un estado penoso, por la merma y la imagen copal. En suma, todas las hayas poseen portes estirados, irregulares, desgarbados, con arquitecturas mal hechas por la fuerte competencia espacial, con troncos variopintos y copas reducidas y desequilibradas, impropias de su rango y condición.

\section{Hayas del Monte de Santa Trega/A Garda}

Al lado de Miguel Reboredo Otero, encargado del Monte de Santa Trega, resultó fácil llegar hasta el Jardín de la ProMonte, prácticamente desaparecido, cuya arboleda superviviente conserva un trío de hayas de tipo silvestre citadas por Rafael Areses (1953), artífice de la repoblación del monte, que indica su posición, "al borde del sendero que va desde la Fuente Vieja a la Nueva", y afirma que son más jóvenes que las del Colegio de Bella Vista/Vigo-, dos mayores y una más pequeña, probablemente nacida de semilla, al borde de un paseo del jardín que debe su nombre a la Sociedad Pro-Monte, responsable de la gestión de los recursos del Monte Santa Trega desde su fundación, que se encargó de la creación del jardín hacia mediados de la década de 1910.

Villa Álvarez (2004), en La Sociedad Pro-Monte Santa Tecla, se refiere al arbolado plantado en este periodo temporal: "En los meses de enero y febrero de 1915, se realizaron importantes plantaciones de árboles de distintas especies, suministrados por el vivero forestal de Areas, en las clases y cantidades siguientes: almeces 250, fresnos 100 , robles del país 250 , robles rojos o americanos 75 , hayas 100, eucaliptos glóbulos 100, eucaliptos amigdalina 75 , cipreses 30 y cedros deodara 30". Circunstancias diversas (pastoreo animal, incendios y otros contratiempos), provocaron la desaparición de muchos árboles.

La información disponible, junto a la entidad del Castro de Santa Trega -declarado zona arqueológica, uno de los bienes de interés cultural más señalados de Galicia-, son aspectos a tener en cuenta a la hora de poner en valor las hayas. Los dos árboles de mayor veteranía muestran portes de similares hechuras, con troncos monopódicos y arquitecturas copales de menor desarrollo a la que le correspondería por antigüedad, debido a razones ambientales (posición de desabrigo, que las convierte en víctimas de embates meteorológicos; calidad del suelo, de poca substancia y déficit hídrico; y topografía adversa, de fuerte pendiente) y plantacionales, por su proximidad, que hace que se mezclen sus arquitecturas componiendo una copa única.

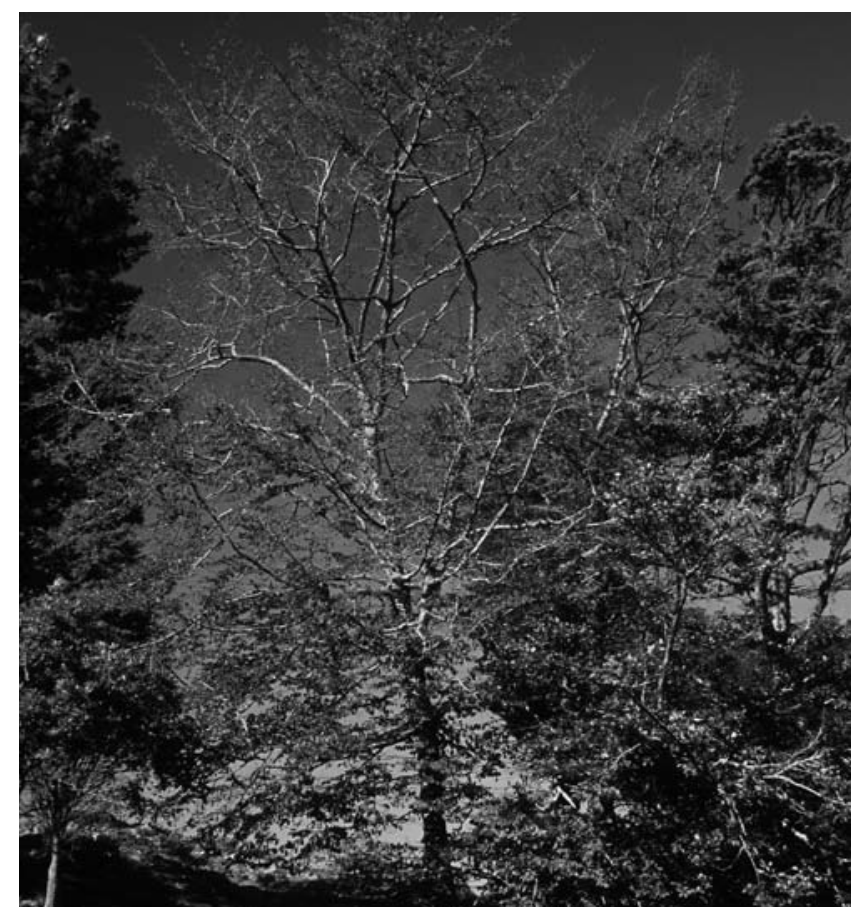

Hayas del Monte de Santa Trega/A Garda

\section{Haya Tricolor de Viveros Juan Peixoto/Tomiño}

En el merendero, frente a la casa familiar y la oficina, figura un haya sobresaliente, por cualidades intrínsecas y extrínsecas. Se trata de un ejemplar de mucha antigüedad, entre 75-100 años, rondando la condición secular en opinión del propietario actual, Juan Peixoto González, descendiente (nieto) de Juan Peixoto Carrera, de origen portugués, fundador del vivero en Goián en 1906 (Rodríguez Dacal, 1990). Bien conservada, la arquitectura y la volumetría del haya están condicionadas y mermadas por el arbolado convecino. Cilindro troncal corto, rematado en una cruz de tres brazos, próximos y verticales, generadores de la copa por descomposición ramificacional. La dendrometría, en consonancia con la vetustez, es muy considerable, tanto en la talla como en lo que al grosor de fuste respecta.

Un hecho a tener en cuenta es la variedad de cultivo, Fagus sylvatica L. 'Tricolor', por su extremada rareza en los jardines, convirtiéndose en un elemento vegetal cuyo aprecio gana muchos enteros por ser el pie de mayor añosidad de su clase cultivado en nuestros lares. En primavera, con la brotación del follaje juvenil, es cuando mejor se aprecian el verde, el granate y el rosado que 
colorean las láminas foliares. Al bagaje de valores intrínsecos, el haya tricolor añade, entre los extrínsecos, el interés viverístico y jardinístico que emana del escenario de cultivo, por tratarse de uno de los establecimientos de mayor solera y antigüedad del país.

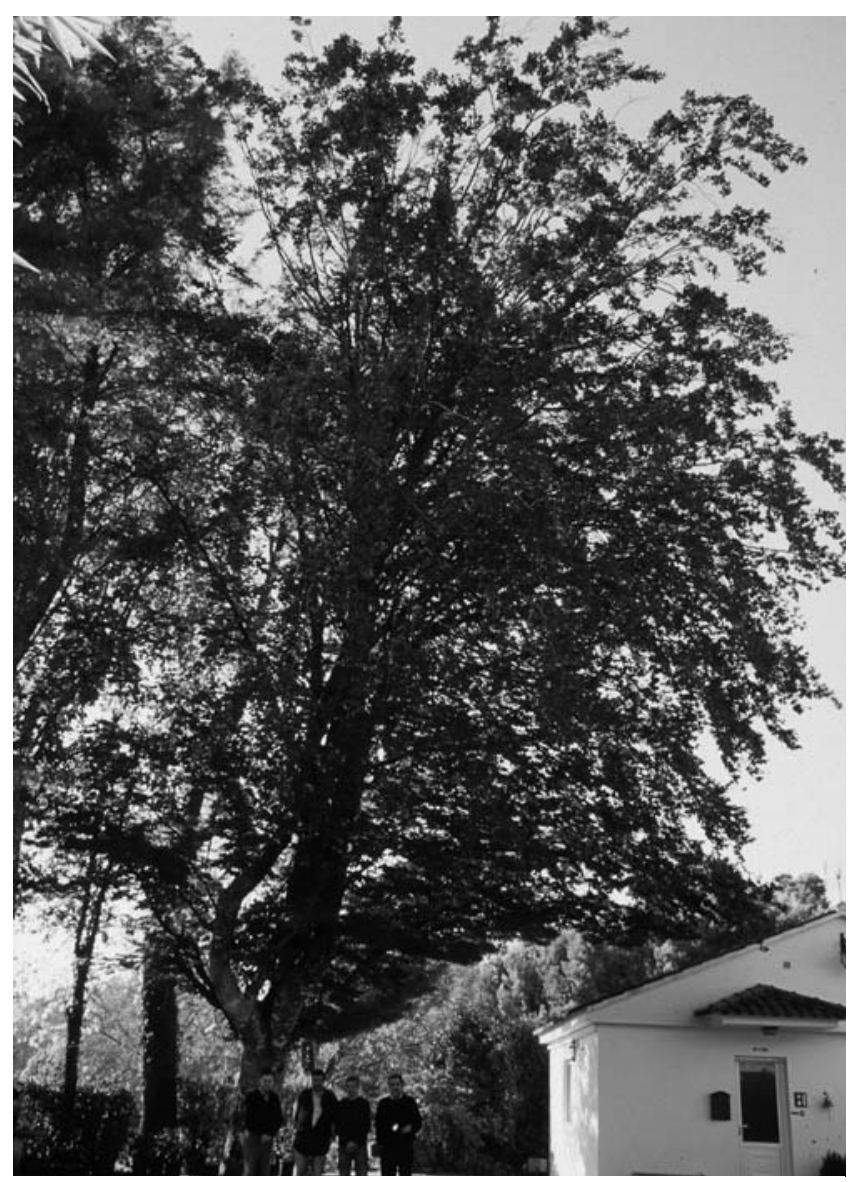

Haya Tricolor de Viveros Juan Peixoto/Tomiño

\section{Hayas del Vivero Forestal de Areas/Tui}

Todo el protagonismo del trío de hayas del tipo silvestre memorables se centra en el lugar de emplazamiento, Vivero Forestal de Areas, y en la figura de Rafael Areses Vidal. Nada juega a favor de estos arbolitos, en el capítulo de méritos propios, por su edad juvenil y la falta de previsión a la hora de su plantación, que los condena a padecer desde el principio de su ciclo vital restricciones espaciales y lumínicas con afectación negativa para su volumetría arquitectónica y fisionomía corporal. Las hayas se encuentran en el entorno de la casa forestal y las dependencias: uno de los ejemplares aparece al borde del paseo de castaños, cerca de un fenomenal Eucalyptus amygdalina (32 x 4,37 m); la pareja restante está en una plazuela, frente a las dependencias.

En loor y gloria de esta obra de Rafael Areses -que conserva sus señas de identidad arquitectónica originales (casa forestal, dependencias, laboratorio, invernadero, pozos, estanque), mantiene sus tablares de cultivos florísticos y sigue prestando el cometido inicial-, incluimos las hayas en el catálogo memorable gallego. Queremos expresar y constatar, con dicha consideración y distinción, el ingente trabajo y la apuesta sin par en pro de la cultura forestal llevados a cabo por tan insigne ingeniero de montes, desde el vivero de su vida personal y quehacer profesional, principal fuente de suministro de árboles existente en Galicia. Desde 1906, entre los pedidos forestales, han figurado los fagus, como lo demuestra Villa Álvarez (2004), al referirse a la repoblación del Monte de Santa Trega/A Garda, y el Archivo del Parque Natural Monte Aloia, donde están depositadas hojas sueltas de Areses que confirman la plantación de hayas en el Monte Aloia/Tui. ¿Cuántas hayas cultivadas en escenarios forestales y ornamentales gallegos, del patrimonio vivo y perdido, habrán salido de este establecimiento forestal?

\section{Hayas del Monte Aloia/Tui}

A nadie se le escapa que la condición de parque natural que ostenta el Monte Aloia es argumento determinante, en el capítulo de atributos ajenos, de cara a la potenciación de la pareja de hayas memorables que viven en él por obra y gracia de Rafael Areses Vidal, aunque los méritos propios, sobre todo en el caso del pie de mayor entidad, bastan por sí mismos para conseguir tal categoría. Con posterioridad, con Gonzalo Puerto Arribas como director del parque, con motivo de su participación en el Plan de Mejora Genética Forestal iniciado en 1985, se encargó personalmente de solicitar al Servicio Forestal de Lugo un pedido de hayas (12 ejemplares), procedentes de semillas del Faial de Pintinidoira, entre As Nogais y Pedrafita do Cebreiro, germinadas en el Vivero de Os Trollos/Bóveda, plantadas en el parque en el invierno de 1991-92; completándose el inventario con un par de plantaciones, del tipo silvestre, practicadas en los albores del nuevo siglo y milenio: la primera, con individuos (4) provinientes del Pazo de Lourizán/Pontevedra, hace ya algunos años; y la segunda, en 2007, a base de pies (12) del Vivero Forestal de Areas/Tui.

En el momento actual, por lo tanto, el cómputo individual se cifra en torno a una treintena de árboles. Por documentación depositada en el Archivo del Parque Natural Monte Aloia (Hojas Sueltas de Rafael Areses Vidal), sabemos que se plantan hayas en el entorno de la Fuente del Santo en el año 1912, procedentes del Vivero Forestal de Areas, referencia -que también figura en una biografía personal del insigne botánico pontevedrés (Parque Natural Monte Aloia, 2000)- que ayuda a establecer la datación cronológica, la autoría y el origen de la plantación de los fagus añosos del parque.

El Haya de la Fuente -que ha adquirido fama y celebridad tras su inclusión en calendarios y publicaciones, la última de Leiro Lois et al. (2006)- es un ejemplar descomunal, de tronco corto y corpulento que forma pronto una cruz de gruesos brazos tentaculares en todas las direcciones, muy abiertos, con distintas inclinaciones, desde la horizontalidad hasta la verticalidad que caracteriza al brazo principal, con soldaduras naturales en lo alto, en el punto de división y encuentro de sus unidades mayores. Los aspectos más llamativos son la extraordinaria volumetría arquitectónica y la configuración del porte, de silueta aovado-redondeada. El 
Haya de la Capilla, en un hábitat menos favorable enclavada en el complejo de escalinatas que baja desde la capilla, próxima a la zona basal-, de menor valor en arquitectura de copa y perimetría de fuste, bien conservada, con el eje troncal como protagonista corporal, ha desarrollado un porte alto y estrecho, estilizado, en medio del arbolado que restringe su espacio vital, expansión volumétrica y campo visual.

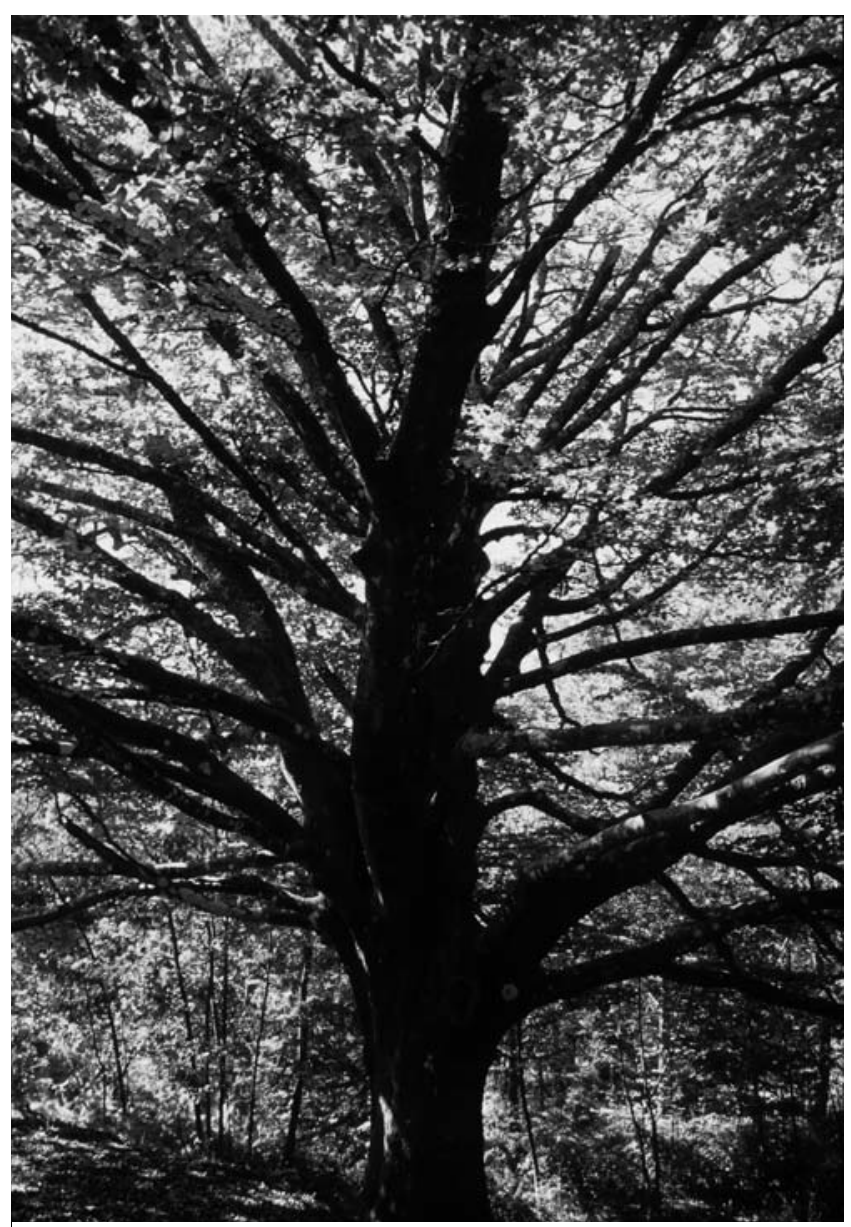

Haya de la Fuente del Monte Aloia/Tui

\section{Haya Purpúrea del Pazo da Mercede/As Neves}

Hermana menor del haya fenomenal muerta en el 2005, recogida en el catálogo de árboles monumentales (Rodríguez Dacal \& Izco, 2003), probablemente nacida de una semilla suya; de ser así, le correspondería la honra de ser hijo legítimo, el de mayor edad, convirtiéndose en continuador de la estirpe. Vive en la terraza inferior del jardín, en posición desabrigada, por lo que los vientos han producido significadas pérdidas de brazos y ramas, cicatrizadas naturalmente por el árbol. A pesar de lo que falta, el pie es portador de una soberbia arquitectura copal, de mucha volumetría, que se adapta al formato típico de la especie. Compite con el arbolado del entorno, de grandes desarrollos, que limitan su espacio, aunque sobresale y muestra su mejor cara hacia la finca del viñedo albariño. La conservación es buena, tanto física como saludablemente.
En el conocimiento y la divulgación de las hayas purpúreas del Pazo da Mercede, hay que hacer referencia, además de la cita monumental, a la mención de Rafael Areses (1953), que habla de un ejemplar en este pazo (suponemos que se trata del hermano mayor, ya desaparecido), y la tesis de Rodríguez Dacal (1990), que incluye ambos árboles. En la puesta en valor de dichas hayas, influyen otros aspectos histórico-culturales, como el asentamiento pacego y la entidad del propietario original, José Elduayen y Gorriti, Marqués del Pazo de la Merced.

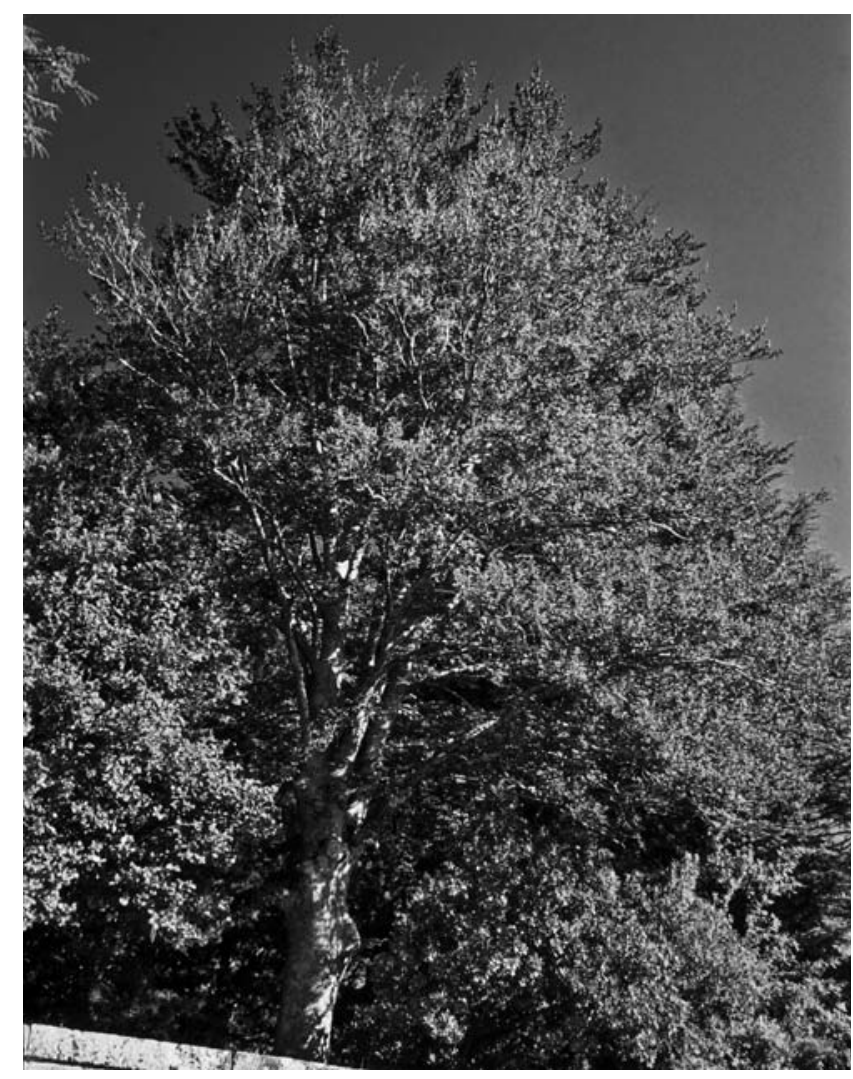

Haya Purpúrea del Paza da Mercede/As Neves

\section{Hayas Memorables Desaparecidas}

El patrimonio de hayas memorables se nutre esencialmente de registros vivos, pero no podemos olvidar aquellos árboles desaparecidos dignos de recuerdo por sus valores intrínsecos y extrínsecos. A falta de fuentes documentales, referencias bibliográficas e información oral, resulta poco menos que misión imposible, hasta el momento, la elaboración del inventario de hayas memorables perdidas que exprese, en términos cuantitativos y cualitativos, su auténtica dimensión, identidad y naturaleza. El trabajo de campo realizado con motivo de la colaboración en el proyecto sobre hayas gallegas, suscrito entre la Universidad de Santiago y la Xunta de Galicia, que trata sobre el papel desempeñado por Fagus sylvatica como especie ornamental (Rodríguez Dacal, en prensa), constituyó una buena oportunidad para abordar esta asignatura pendiente, a través de un muestrario inicial de ejemplares que, a lo largo de su vida, han sido objeto de atención e interés -por 
méritos propios y atributos ajenos (históricos, culturales y botánicos)-, de tal manera que su conocimiento cuenta con testimonios escritos y visuales, serios y rigurosos, que permiten su memoria y su recuerdo. A buen seguro que, más pronto que tarde, el catálogo se enriquecerá y diversificará con nuevas incorporaciones. Por la entidad de los registros individuales, se hace una caracterización de dicho muestrario.

\section{+ Haya Péndula de Villa Eugenia/Culleredo}

En el lugar de Hombre y parroquia de San Julián de Almeiras. A tenor de la dendrometría troncal anotada en el Inventario de Árboles Sobresalientes de Galicia (Xunta de Galicia, 1985) le corresponde ocupar, entre el material conocido, la primera posición del listado de hayas cultivadas de ornato en lo que a grosor troncal respecta. La importancia individual queda recogida en el apartado de datos históricos o culturales de dicho inventario: "Ejemplar excepcional, por pertenecer a una curiosísima variedad, siendo el único ejemplar de esas características del que tenemos constancia en Galicia"; con otra noticia preocupante en las observaciones finales: "Se encuentra expuesto a su posible pérdida como consecuencia de las obras proyectadas para la ampliación del aeropuerto de Alvedro".

Poco tiempo transcurrió para que la premonición se convirtiese en realidad, de tal manera que la finca ha desaparecido, con todo su contenido arquitectónico, presidido por casona y capilla, y botánico, con jardín y arbolado vetusto; salvándose algunos ejemplares (palmeras canarias) que fueron transplantados hasta la zona ajardinada del aeropuerto, sin suerte para el haya péndula que, desde entonces, en torno a un par de décadas, pertenece al patrimonio perdido. La dendrometría y la edad que figuran en el cuadro de datos geográficos y biométricos de hayas memorables desaparecidas (Rodríguez Dacal, en prensa) procede del Inventario de Árboles Sobresalientes de la Xunta de Galicia. En la dendrometría troncal, se indica el diámetro $(1,50 \mathrm{~m})$, que convertido en circunferencia arroja un valor de 4,71 m; y en la copa, su proyección (369 $\left.\mathrm{m}^{2}\right)$, en vez del diámetro máximo y el perpendicular a éste. La edad se estima superior a 100 años.

\section{+ Haya del Pazo de San Lourenzo/Santiago}

Es el representante más señero del patrimonio memorable de hayas desaparecidas, por causas naturales relacionadas con la edad y su estado fitosanitario. Su conocimiento y difusión por todo el país se deben, en gran medida, a la cita en la flora del Padre Merino (1905-1909); a su inclusión en la tesis de Rodríguez Dacal (1990); a su mención en el libro sobre jardines y plantas de pazos (Rodríguez Dacal \& Izco, 1994); así como a su incorporación al catalogo de árboles monumentales gallegos (Rodríguez Dacal \& Izco, 2003). Ejemplar secular, del último cuarto del siglo XIX, de considerable entidad dendrométrica -21,5 m/6,5 m/3,25 $\mathrm{m} / 19 \mathrm{~m} \times 17 \mathrm{~m}$-, provisto de gran tronco, monopódico durante largo trecho, y copa amplia de contorno aovadoredondeado. Vegetaba en el Jardín Paisajista, extendido al pie de la fachada oeste del edificio residencial, próximo a él, en estrecha vecindad a la muralla que corre paralela a la carretera, en la parte alta de la finca. A buen seguro, es el progenitor de una parte de la colección de hayas localizadas en el pazo.

\section{+ Haya Purpúrea del Pazo de Torrecedeira/Redondela}

Hasta el momento de su pérdida, le correspondió la honra de ser uno de los representantes de su especie de mayor trascendencia de los lares gallegos. Rodríguez Dacal (1990) da cuenta de un par de hayas monumentales en este pazo pontevedrés. Años después, en el catálogo arbóreo monumental (Rodríguez Dacal \& Izco, 2003) aparece una sola, la de mayor dendrometría, por muerte del otro ejemplar (32 m x 3,75 m). Sin duda, de seguir con vida, su consideración monumental estaba asegurada, no en vano ocupaba el segundo lugar, en lo que a dendrometría respecta, entre las hayas conocidas cultivadas en los jardines del país. Su desaparición se produjo por causas naturales, sin relación con inclemencias, a finales de la década de 1990, siendo la causa de su derribo en el parque la rotura del tronco, afectado por un avanzado proceso de pudrición y oquedad.

\section{+ Haya del Colegio de Bella Vista/Vigo}

Citada con este nombre por Rafael Areses (1953) -como árbol de cuantiosa dendrometría, por la comparación establecida con los pies que vegetan en el Monte de Santa Trega/A Garda, de menor edad-, por lo que, como quiera que ha desaparecido hará cuestión de un cuarto de siglo, respetamos la denominación del ilustre botánico, a sabiendas de que hoy sería más correcto llamarla Haya del Colegio Apóstol Santiago. La finca -con su casona, parcelas hortícolas, ganaderas y jardinísticas, con protagonismo para el bosque-jardín- fue adquirida por la Compañía de Jesús (Jesuitas) a Ángel Elduayen, hijo de José Elduayen y Gorriti. La primera piedra del colegio se colocó en 1926 y la inauguración tuvo lugar en 1928. El hermano José Bailón Bailón, que está en el colegio desde 1964, ha actuado como hilo conductor de hechos y acontecimientos históricos. En su opinión, el haya de tipo silvestre, que destacaba por sus medidas, tanto la talla como el grosor troncal, estaba en la parte inferior del bosque ornamental, desapareciendo por sequedad. El fuste fue troceado, depositándose en un almacén, siendo destinada la madera, en años sucesivos, como material de carpintería para las clases de trabajos manuales; lamentablemente, no se conservan restos.

Con fines histórico-culturales, noticiar a un jesuíta honorable, el Padre Baltasar Merino, y su conexión con Rafael Areses, natural de Tui, que estudió el bachillerato en el Colegio de la Compañía de Jesús de Camposancos, donde tuvo como profesor a tan calificado botánico. ¿Habrá tenido algo que ver Areses Vidal con la plantación ornamental, cuando menos del haya, del colegio jesuíta vigués?

\section{+ Haya Purpúrea del Pazo de Castrelos/Vigo}

Como quien dice, acaba de causar baja en el patrimonio monumental viviente, editado en la obra de Rodríguez Dacal \& Izco (2003). Pero, por fortuna, la publicación recoge su existencia, con una fotografía en color de su arquitectura corporal, retrato que garantiza su inmortalidad fisionómica. Aunque no figure con nombre propio, integra el colectivo 


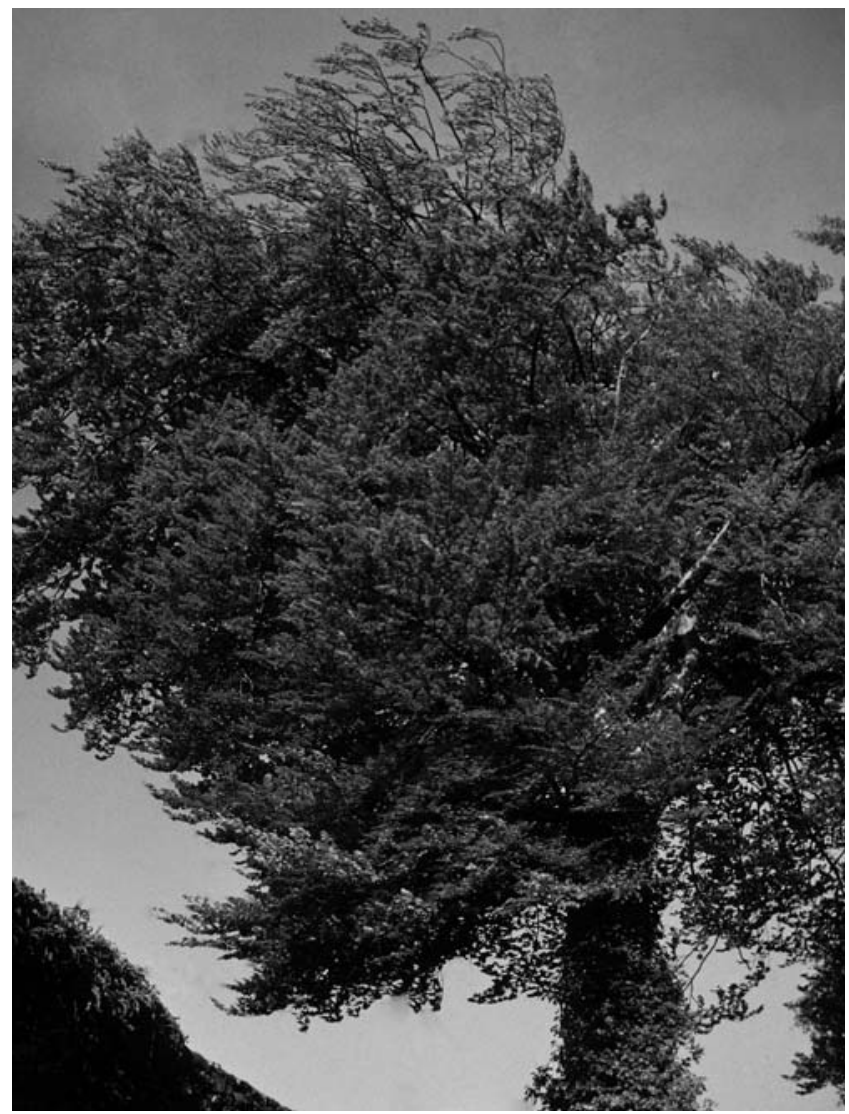

Haya del Pazo de San Lourenzo/Santiago de Compostela

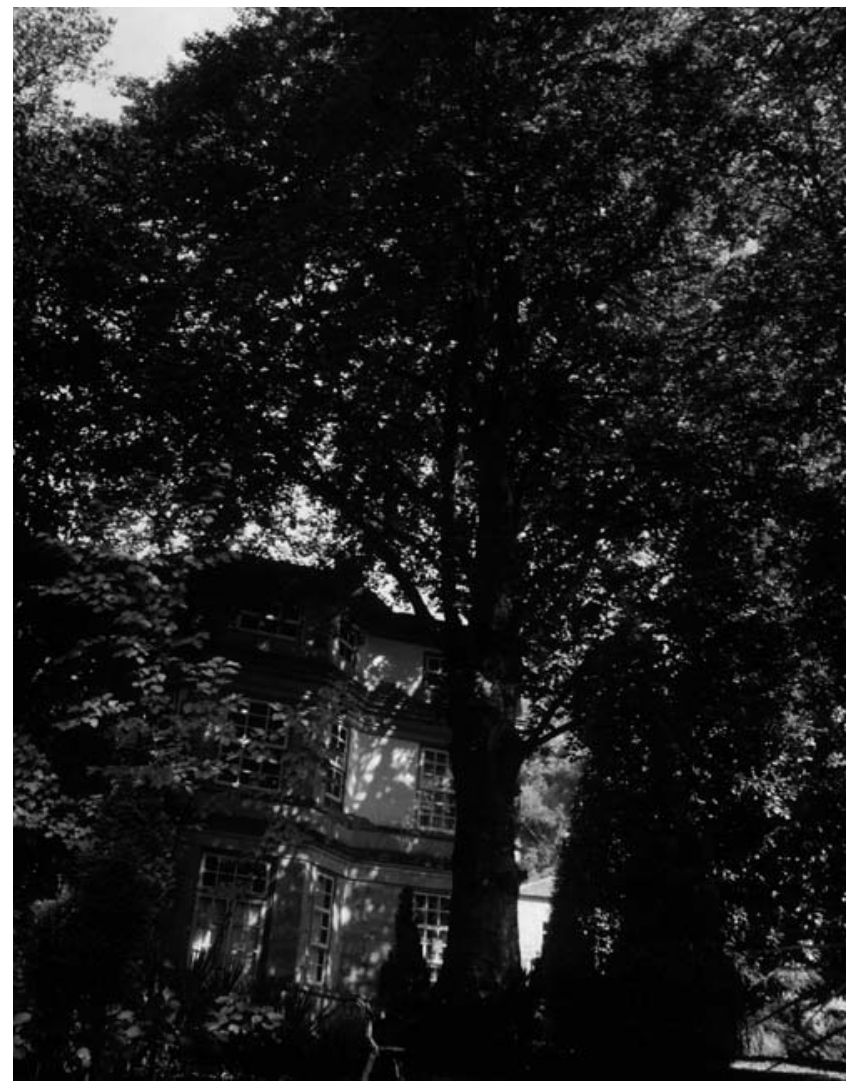

Haya Purpúrea del Pazo da Mercede/As Neves

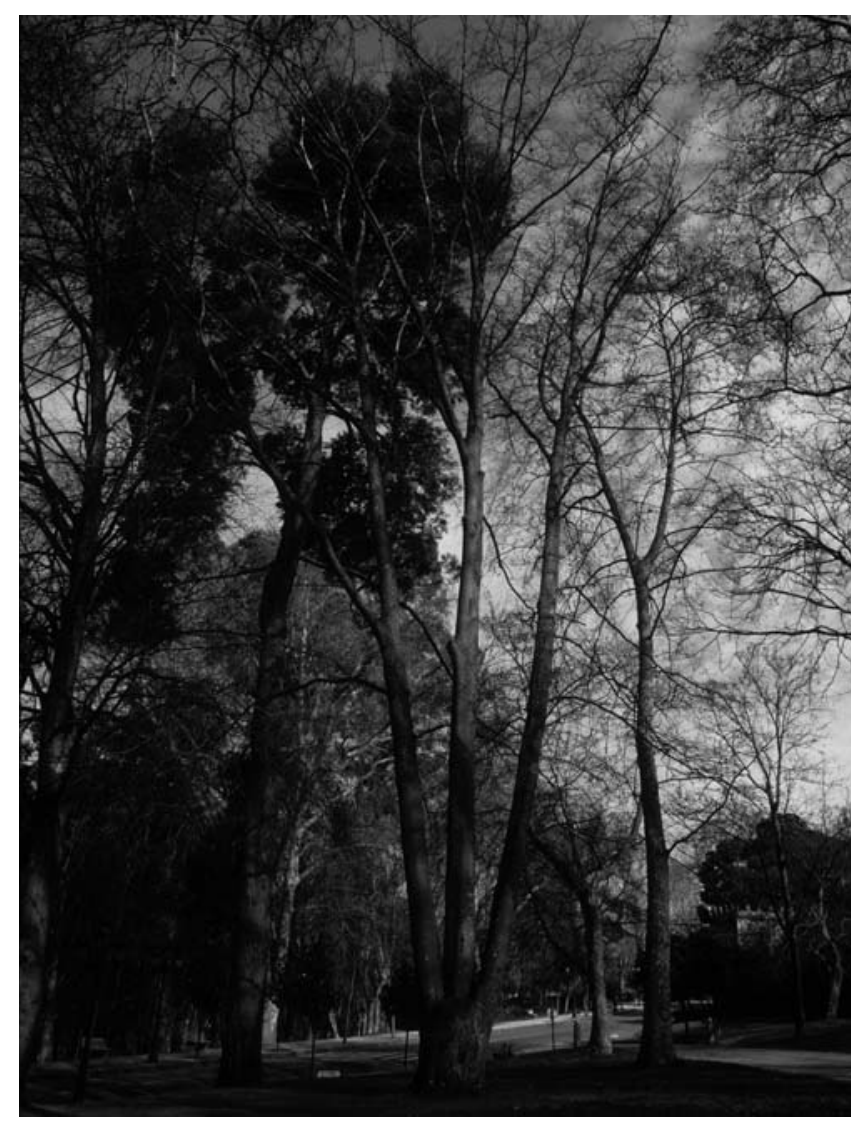

Haya Purpúrea del Pazo de Castrelos/Vigo

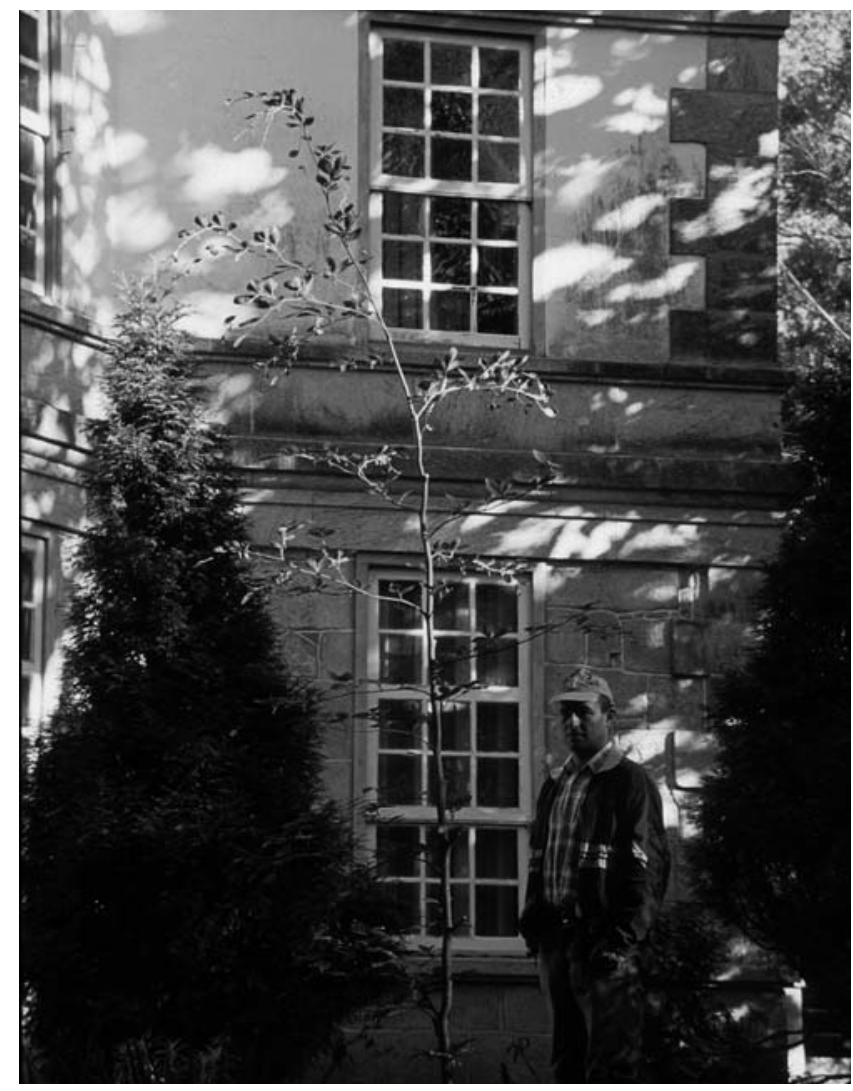

Haya Purpúrea sustituta del Pazo da Mercede/As Neves 
referido por Rodríguez Dacal \& Izco (1994) y Fernández Alonso \& Rigueiro Rodríguez (2001). En su lado positivo, era el árbol con fuste de mayor perimetría, superior a $4 \mathrm{~m}$ de cuerda, grosor beneficiado por el arranque de la horquilla, a metro y medio del suelo, en cuatro brazos; siendo notable su talla, por encima de la treintena de metros. En su lado negativo, comentar su deterioro corporal, el mayor del grupo, por pérdida de uno de los brazos integrantes de su cruz, con superficie de amputación tratada fitosanitariamente; y por mostrar un evidente grado de sequedad y defoliación de su ramaje.

\section{+ Haya Purpúrea del Pazo da Mercede/As Neves}

Ante la fachada posterior de la casona -con tronco imponente, de base ensanchada, cilíndrico y monopódico hasta la cruz-, ostentaba un porte con fisionomía y dendrometría muy significada, llamando la atención de Rafael Areses (1953). Plantada en el último cuarto del siglo XIX, gozaba de buen estado fitosanitario, libre de connotaciones negativas relevantes, con la salvedad de la pudrición basal del fuste por su cara norte, único signo de preocupación. Además de su elevada talla $(30 \mathrm{~m})$ y su considerable volumetría, frondosidad y umbrosidad copal, lo más noticiable era el grosor troncal $(3,90 \mathrm{~m})$, cifra que la aupó en vida hasta el segundo lugar en el escalafón en lo que a perimetría del fuste respecta.

El año 2005 marcó el punto y final, causando sorpresa su muerte por inesperada. En febrero del 2006, un día ventoso produjo su derribo, rompiendo por la base troncal, a medio metro del suelo. Un haya purpúrea, de $3 \mathrm{~m}$, nacida de una semilla suya hace más de una década, fue colocada a finales de dicho mes como árbol sustituto.

\section{Documentación y bibliografía}

Archivo del Parque Natural Monte Aloia. Documentación de Rafael Areses Vidal: Hojas Sueltas. Parque Natural Monte Aloia.

Archivo del Pazo de Santa Cruz de Ribadulla. Libretas del Tío Iván. Pazo de Santa Cruz de Ribadulla. Vedra.

Areses, R. (1953). Nuestros Parques y Jardines. Contribución al Conocimiento de las Plantas Exóticas Cultivadas en España. Galicia. Tomo I - Pontevedra. Escuela Especial de Ingenieros de Montes. Madrid.

Blanco-Dios, J.B. (2005). Centro de Investigacións Forestais e Ambientais de Lourizán. Xardín Botánico. Dirección Xeral de Desenvolvemento Sostible. Consellería de Medio Ambiente. Xunta de Galicia.

Casa Jacinto de Matthos (sin fecha). Catálogo Geral de Plantas para Jardines, Parques e Pomares. Casa Jacinto de Matthos. Porto.

Castillo Fondevila, M.E. (2003). La Saleta. Jardín Botánico. Colección Naturaleza Gallega. Servicio de Publicacións. Excma. Deputación Provincial de Pontevedra.

Castro, Fr. J. de (1722). Primera Parte de El Arbol Chronologico de la Santa Provincia de Santiago. Francisco García Onorato y San Miguel. Salamanca.
Castro, M., Freire, L. \& Prunell, A. (1989). Guía das Árbores de Galicia (Autóctonas e Ornamentais). Edicións Xerais de Galicia. Vigo.

Chouza Mata, M. \& Cid González, R. (1986). As Árbores. Cadernos Museo do Pobo Galego 4. Santiago de Compostela.

Cid González, R. \& Chouza Mata, M. (1982). As Árbores de Compostela. Comisión de Educación e Cultura. Axuntamento de Santiago.

Diario Oficial de Galicia (2007). Decreto polo que se regula o Catálogo Galego de Árbores Senlleiras, 74 (17 de Abril): 6.136-6.142.

Fernández Alonso, J.I. \& Rigueiro Rodríguez, A. (2001). Catálogo das Árbores Singulares do Concello de Vigo. Colección Documentos de Medio Ambiente 2. Concello de Vigo.

Fernández de Ana Magán, F.J. \& Álvarez Fernández, D. (1994). Lourizán, de Pazo Solariego a Centro de Investigaciones Forestales. Artes Graficas Portela, S. L. Pontevedra.

Florez, Fr.H. (1765). Viage de Ambrosio de Morales por Orden del Rey D. Phelipe II a los Reynos de Leon, y Galicia, y Principado de Asturias para Reconocer las Reliquias de Santos, Sepulcros Reales, y Libros Manufcritos de las Catedrales, y Monafterios. Antonio Marín. Madrid.

Leiro Lois, A., Daporta Padín, M., Caamaño Rivas, V.M., Núñez Pérez, M., Pontanilla Pérez, I. \& Colazo Pazó, X. (2006). Árbores de Galiza. A Nosa Terra.

Licenciado Molina, B.S. (1550). Descripción del Reino de Galizia y de las Cosas Notables del, con las Armas y Blasones de los Linajes de Galizia de donde proceden señaladas Casas en Castilla. Mondoñedo.

López, A. (1820). Consideraciones Generales sobre varios Puntos Históricos, Políticos y Económicos, á Favor de la Libertad y Fomento de los Pueblos, y Noticias Particulares de esta Clase, relativas al Ferrol y su Comarca. Tomo I. Imprenta de M. Repullés. Madrid.

Merino, R. P. B. (1905-1909). Flora Descriptiva e Ilustrada de Galicia. Tipografía Galaica. Santiago.

Moralejo, A., Torres, C. \& Feo, J. (1998). Liber Sancti Jacobi "Codex Calixtinus". Xerencia de Promoción do Camiño de Santiago. Consellería de Cultura, Comunicación Social e Turismo. Xunta de Galicia.

Páez de la Cadena, F. (1982). Historia de los Estilos en Jardinería. Colección Fundamentos 84. Ediciones ISTMO. Madrid.

Pakenham, T. (2004). Árboles Excepcionales del Mundo. Editado por Blume. Barcelona.

Parque Natural Monte Aloia (2000). D. Rafael Areses Vidal. Biografía dun Home dedicado ós Bosques de Galicia. Dirección Xeral de Montes e Medio Ambiente Natural. Consellería de Medio Ambiente. Xunta de Galicia. 
Prunell Tuduri, A., Vales Mosquera, E. \& Fernández Abraldes, F. (1987). Árboles de los Jardines de Méndez Núñez. Servicio Municipal de Educación. Ayuntamiento de La Coruña.

Pulgar Sañudo, I. (2005). Guía de la Flora del Parque Natural Baixa Limia-Serra do Xurés. Segunda Edición. Consellería de Medio Ambiente. Xunta de Galicia.

Rigueiro Rodríguez, A., Castro Cerceda, M.,Freire García, L., Martínez Piñeiro, J., López Prada, I. \& Regueiro Sánchez, M. (1995). Guía Botánica do Parque Rosalía de Castro. Servicio de Publicacións. Deputación Provincial de Lugo.

Rodríguez Dacal, C. (1990). Flora Leñosa Ornamental Pacega de Galicia Occidental. Tesis Doctoral (Inédita). Departamento de Biología Vegetal. Facultad de Biología. Universidad de Santiago.

Rodríguez Dacal, C. (1997a). Alamedas, Jardines y Parques de Galicia. Dirección de Calidade Medioambiental e Urbanismo. Consellería de Política Territorial, Obras Públicas e Vivenda. Xunta de Galicia.

Rodríguez Dacal, C. (1997b). El Parque-Jardín de Caldas de Reis. Concellería de Medio Ambiente, Sanidade e Rural. Concello de Caldas de Reis.

Rodríguez Dacal, C. (1999). El Parque-Jardín y la Carballeira de Caldas de Reis. Paraje Pintoresco y Jardín Histórico. Ayuntamiento de Caldas de Reis.

Rodríguez Dacal, C. (en prensa). Fagus sylvatica L., Especie Ornamental. Os Faiais de Galicia. Ecoloxía e Valor Ambiental (Rodríguez Guitián \& Rigueiro Rodríguez, coords.): 445-486. Dirección Xeral de Conservación da Natureza. Consellería do Medio Rural. Xunta de Galicia. Santiago de Compostela.
Rodríguez Dacal, C. \& Izco, J. (1994). Pazos de Galicia. Jardines y Plantas. Consellería de Presidencia y Administración Pública. Xunta de Galicia.

Rodríguez Dacal, C. \& Izco, J. (2003). Árboles Monumentales en el Patrimonio Cultural de Galicia. 2 Tomos. Consellería de Cultura, Comunicación Social e Turismo. Xunta de Galicia.

Rodríguez Guitián, M.A. \& Rigueiro Rodríguez, A. (en prensa). Os Faiais de Galicia. Ecoloxía e Valor Ambiental. Dirección Xeral de Conservación da Natureza. Consellería do Medio Rural. Xunta de Galicia. Santiago de Compostela.

Sa Bravo, H. de (1983). Boticas Monacales y Medicina Naturista en Galicia. Editorial Everest. León.

Salvat Editores (1978). Flora. Enciclopedia Salvat de la Jardinería. Tomo 6. Salvat Editores, S. A. Barcelona.

Villa Álvarez, J.M. (2004). La Sociedad Pro-Monte Santa Tecla (1ª Parte: 1912 -1928). Serie "Las Sociedades de La Guardia y su Comarca". Edita Patronato Municipal do Monte Santa Tegra. A Guarda.

Xunta de Galicia (1985). Inventario de Árboles Sobresalientes de Galicia. Dirección Xeral do Forestal e do Medio Ambiente de la Consellería de Agricultura, Pesca y Alimentación. Xunta de Galicia. 
Cuadro de datos geográficos y biométricos de hayas ornamentales memorables vivas de Galicia (Rodríguez Dacal, en prensa)

\begin{tabular}{|c|c|c|c|c|}
\hline Localización & Municipio & Altitud (m) & Dendrometría (m) & Edad (años) \\
\hline Pazo de Xaz (co) & Oleiros & 70 & $23 / 7,5 / 2,19 / 17 \times 14$ & $75-100$ \\
\hline Pazo de Xaz (co) & Oleiros & 70 & $28 / 8 / 1,93 / 14 \times 13$ & $75-100$ \\
\hline Pazo de Xaz (co) & Oleiros & 70 & $22 / 7 / 2,17 / 17 \times 15$ & $75-100$ \\
\hline Pazo do Casal (co) & Bergondo & 90 & $24 / 13 / 1,90 / 18 \times 13$ & $75-100$ \\
\hline Pazo do Casal (co) & Bergondo & 90 & $23 / 8,5 / 1,73 / 16 \times 14$ & $75-100$ \\
\hline Jardines de Méndez Núñez (pu) & A Coruña & $<5$ & $18 / 0,5-1 / 3,90 / 20,5 \times 20,5$ & $75-100$ \\
\hline Jardines de Méndez Núñez (co) & A Coruña & $<5$ & $18 / 2 / 1,78 / 14 \times 12$ & $75-100$ \\
\hline Jardines de Méndez Núñez (co) & A Coruña & $<5$ & $19 / 0,5-1 / 1,84 / 14 \times 13,5$ & $75-100$ \\
\hline Monasterio de Santa María (co) & Sobrado & 520 & $9,5 / 0,5 / 1,48 / 11 \times 10$ & $25-30$ \\
\hline Monasterio de Santa Maria (co) & Sobrado & 520 & $10 / 0,75 / 1,45 / 10,5 \times 9$ & $25-30$ \\
\hline Monasterio de Santa María (co) & Sobrado & 520 & $11,5 / 1,5 / 1,30 / 10,5 \times 10$ & $25-30$ \\
\hline Pazo do Picón (co) & O Pino & 290 & $25 / 1,75 / 1,94 / 14 \times 12$ & $50-75$ \\
\hline Pazo do Picón (co) & O Pino & 290 & $26 / 1,75 / 1,86 / 17 \times 13$ & $50-75$ \\
\hline Pazo de Casanova (co) & O Pino & 310 & $37 / 5 / 2,41 / 22 \times 14$ & $100-125$ \\
\hline Pazo de Casanova (co) & O Pino & 310 & $39 / 6 / 2,35 / 18 \times 16$ & $100-125$ \\
\hline Pazo de Casanova (co) & O Pino & 310 & $36 / 3,5 / 2,22 / 17 \times 13$ & $100-125$ \\
\hline Pazo de Casanova (co) & O Pino & 310 & $34 / 10 / 2,14 / 19 \times 17$ & $100-125$ \\
\hline Pazo de San Lourenzo (co) & Santiago & 230 & $22 / 6 / 2,97 / 19 \times 16$ & $100-125$ \\
\hline Pazo de San Lourenzo (co) & Santiago & 230 & $23 / 8,5 / 2,89 / 18 \times 17$ & $100-125$ \\
\hline Pazo de San Lourenzo (co) & Santiago & 230 & $24 / 4,5 / 2,74 / 18 \times 13$ & $100-125$ \\
\hline Pazo de San Lourenzo (co) & Santiago & 230 & $21 / 8 / 2,73 / 22 \times 16$ & $100-125$ \\
\hline Pazo de San Lourenzo (co) & Santiago & 230 & $21 / 4,5 / 2,70 / 22 \times 19$ & $100-125$ \\
\hline Pazo de San Lourenzo (co) & Santiago & 230 & $22 / 7 / 2,46 / 17,5 \times 16$ & $75-100$ \\
\hline Pazo de San Lourenzo (co) & Santiago & 230 & $22 / 5,5 / 2,33 / 21,5 \times 16$ & $75-100$ \\
\hline Campus Universitario (co) & Santiago & 240 & $27 / 2 / 3,35 / 28 \times 25$ & $100-125$ \\
\hline Campus Universitario (co) & Santiago & 240 & $25 / 2,5 / 3,24 / 21 \times 21$ & $100-125$ \\
\hline Campus Universitario (co) & Santiago & 240 & $26 / 3,5 / 3,13 / 27 \times 26$ & $100-125$ \\
\hline Campus Universitario (co) & Santiago & 240 & $24 / 1,5 / 2,95 / 22 \times 22$ & $100-125$ \\
\hline Centro Agroforestal Sergude (co) & Boqueixón & 220 & $11,5 / 1 / 1,95 / 10,5 \times 10,5$ & $20-30$ \\
\hline Centro Agroforestal Sergude (co) & Boqueixón & 220 & $13,5 / 1,5 / 1,15 / 11 \times 9,5$ & $20-30$ \\
\hline Centro Agroforestal Sergude (co) & Boqueixón & 220 & $10,5 / 0,5-1 / 0,94 / 10 \times 8$ & $20-30$ \\
\hline Centro Agroforestal Sergude (co) & Boqueixón & 220 & $8,5 / 0,5 / 0,90 / 7,5 \times 7$ & $20-30$ \\
\hline Pazo de Santa Cruz (co) & Vedra & 160 & $>40 / 14 / 3,20 / 14 \times 14$ & $100-125$ \\
\hline Pazo de Santa Cruz (co) & Vedra & 160 & $>40 / 6 / 2,62 / 20 \times 16$ & $100-125$ \\
\hline Pazo de Santa Cruz (co) & Vedra & 160 & $>40 / 5 / 2,45 / 15 \times 14$ & $100-125$ \\
\hline Jardin Botánico-Artístico $(c o)$ & Padrón & 10 & $2,5 / 1,75 / 0,30 / 2 \times 2$ & $10-15$ \\
\hline Pazo de Antequeira (co) & Rois & 90 & $26 / 4 / 3,40 / 24 \times 24$ & $100-125$ \\
\hline Monte Faro (co) & Chantada & 1.000 & $9 / 1,25 / 0,70 / 6,5 \times 6$ & $15-20$ \\
\hline Casa de Cuiña (co) & Guntín & 490 & $17 / 4 / 2,05 / 16 \times 15$ & $50-75$ \\
\hline Casa de Cuiña (co) & Guntín & 490 & $13,5 / 2 / 1,15 / 12,5 \times 12$ & $50-75$ \\
\hline Casa de Cuiña (co) & Guntín & 490 & $15,5 / 10,5 / 1,06 / 13 \times 12$ & $50-75$ \\
\hline Balneario (co) & Guitiriz & 450 & $18 / 5,5 / 1,79 / 12 \times 11$ & $50-75$ \\
\hline Casa Souto Montenegro (co) & Begonte & 445 & $25 / 7 / 2,74 / 18,5 \times 15$ & $75-100$ \\
\hline Bosquete das Modias (co) & Begonte & 445 & $18 / 5 / 2,40 / 15 \times 15$ & $75-100$ \\
\hline Bosquete das Modias (co) & Begonte & 445 & $19,5 / 6 / 2,31 / 15 \times 14$ & $75-100$ \\
\hline CEIP Virxe do Corpiño (co) & Begonte & 425 & $18,5 / 2-3 / 2,05 / 13 \times 11,5$ & $75-100$ \\
\hline Parque Fluvial (co) & Begonte & 395 & $19 / 6 / 2,95 / 18 \times 17$ & $75-100$ \\
\hline Parque Fluvial (co) & Begonte & 395 & $23 / 2,5 / 2,53 / 14 \times 11$ & $75-100$ \\
\hline Parque Fluvial (co) & Begonte & 395 & $14,5 / 2 / 2,10 / 17 \times 12$ & $75-100$ \\
\hline Alameda de la Plaza Mayor (co) & Lugo & 460 & $9 / 4,5 / 0,41 / 3 \times 3$ & $5-10$ \\
\hline Parque de Rosalía de Castro (co) & Lugo & 460 & $18,5 / 7 / 2,05 / 14 \times 11$ & $80-90$ \\
\hline Parque de Rosalía de Castro (co) & Lugo & 460 & $21 / 8 / 1,71 / 14 \times 13$ & $80-90$ \\
\hline Cantera de Sasdónigas (co) & Mondoñedo & 400 & $27 / 16 / 2,80 / 24 \times 21$ & $75-100$ \\
\hline Cantera de Sasdónigas (co) & Mondoñedo & 400 & $26 / 14 / 2,05 / 16 \times 16$ & $75-100$ \\
\hline Haya de la Casa de Cosme (co) & Pol & 570 & $19,5 / 5,5 / 2 / 13 \times 13$ & $80-90$ \\
\hline
\end{tabular}


Cuadro de datos geográficos y biométricos de hayas ornamentales memorables vivas de Galicia (continuación) (Rodríguez Dacal, en prensa)

\begin{tabular}{|c|c|c|c|c|}
\hline Localización & Municipio & Altitud (m) & Dendrometría (m) & Edad (años) \\
\hline Pazo de Lusío (co) & Samos & 600 & $22 / 9 / 1,70 / 18 \times 15$ & $75-100$ \\
\hline Santuario de Santa María (co) & Pedrafita & 1.300 & $9,5 / 6,25 / 1,02 / 7,5 \times 6,5$ & $30-40$ \\
\hline Santuario de Santa María (co) & Pedrafita & 1.300 & $8 / 0,75 / 1 / 8 \times 6$ & $30-40$ \\
\hline Finca dos Penedais (pu) & Ribadeo & 95 & $26 / 4-5 / 3 / 22,5 \times 22,5$ & $75-100$ \\
\hline Pazo de Fontao (co) & Foz & 100 & $12,5 / 1,5-2 / 0,85 / 9 \times 8$ & $20-25$ \\
\hline Pazo de Fontao (co) & Foz & 100 & $10,5 / 1,5 / 0,82 / 10 \times 7,5$ & $20-25$ \\
\hline Casa da Abureira (co) & A Pontenova & 150 & $21 / 2,5 / 1,37 / 13 \times 11$ & $40-60$ \\
\hline Serra de Enciña da Lastra (co) & Rubiá & 750 & $15 / 2,5 / 1,05 / 9 \times 8$ & $20-25$ \\
\hline Serra de Enciña da Lastra (co) & Rubiá & 750 & $13 / 6,5 / 0,98 / 9 \times 7,5$ & $20-25$ \\
\hline Parque Municipal (pu) & O Carballiño & 420 & $9,5 / 2,5 / 0,70 / 8,5 \times 8$ & $10-15$ \\
\hline Parque Municipal (pu) & O Carballiño & 420 & $9,5 / 2,5 / 0,66 / 6 \times 6$ & $10-15$ \\
\hline Fervenza do Muíno (co) & Celanova & 485 & $25 / 17 / 1,38 / 17 \times 14,5$ & $50-75$ \\
\hline Balneario de Cabreiroá (co) & Verín & 385 & $13 / 5 / 0,59 / 8 \times 7$ & $15-20$ \\
\hline Serra do Xurés (co) & Lobios & 800 & $22 / 13 / 1,40 / 15,5 \times 12$ & $50-75$ \\
\hline Serra do Xurés (co) & Lobios & 800 & $24 / 5 / 1,18 / 9,5 \times 9,5$ & $50-75$ \\
\hline Serra do Xurés (co) & Lobios & 800 & $22 / 7 / 1,08 / 13 \times 11,5$ & $50-75$ \\
\hline Pazo de Vista Alegre (co) & Vilagarcía & $<5$ & $25 / 6 / 2,50 / 19 \times 17$ & $75-100$ \\
\hline Parque-Jardín y Carballeira (co) & Caldas Reis & 30 & $14 / 7 / 0,80 / 10 \times 10$ & $15-20$ \\
\hline UNEDICentro Regional (pu) & Pontevedra & 65 & $21 / 2 / 3,20 / 18 \times 16$ & $100-125$ \\
\hline Pazo de Lourizán (co) & Pontevedra & 70 & $22 / 7 / 1,63 / 15 \times 14$ & $50-75$ \\
\hline Pazo de Lourizán (co) & Pontevedra & 70 & $20 / 2 / 1,38 / 18 \times 18$ & $50-75$ \\
\hline Pazo de Lourizán (co) & Pontevedra & 70 & $18 / 2 / 1,35 / 12 \times 11$ & $50-75$ \\
\hline Pazo de Torrecedeira (pu) & Redondela & 120 & $36 / 5,5 / 4,24 / 25 \times 20$ & $125-150$ \\
\hline Pazo de Castrelos (co) & Vigo & 50 & $42 / 4 / 3,59 / 27 \times 25$ & $100-125$ \\
\hline Pazo de Castrelos (co) & Vigo & 50 & $33 / 4 / 3,39 / 20 \times 20$ & $100-125$ \\
\hline Pazo de Castrelos (pu) & Vigo & 50 & $33 / 2,5 / 2,71 / 16 \times 12$ & $100-125$ \\
\hline Pazo de Castrelos (pu) & Vigo & 50 & $31 / 9 / 2,51 / 20 \times 16,5$ & $100-125$ \\
\hline Pazo de Castrelos (pu) & Vigo & 50 & $27 / 11 / 2,25 / 19 \times 19$ & $100-125$ \\
\hline Pazo de Castrelos (pu) & Vigo & 50 & $28 / 15 / 2,22 / 17,5 \times 17$ & $100-125$ \\
\hline Castillo de Monte Real (co) & Baiona & 30 & $11,5 / 1,5 / 0,70 / 8 \times 7$ & $10-15$ \\
\hline Castillo de Monte Real (co) & Baiona & 30 & $9,5 / 5,5 / 0,50 / 7 \times 7$ & $10-15$ \\
\hline Monte de Santa Tegra (co) & A Garda & 255 & $19,5 / 9 / 1,59 / 12,5 \times 10$ & $75-100$ \\
\hline Monte de Santa Tegra (co) & A Garda & 255 & $18,5 / 7 / 1,42 / 12 \times 10$ & $75-100$ \\
\hline Monte de Santa Tegra (co) & A Garda & 255 & $11,5 / 6 / 1,03 / 12,5 \times 10$ & $50-75$ \\
\hline Viveros Juan Peixoto (tri) & Tomiño & 25 & $23 / 2 / 1,92 / 17,5 \times 13$ & $75-100$ \\
\hline Monte Aloia (co) & Tui & 375 & $23 / 2 / 3,19 / 31 \times 27$ & $75-100$ \\
\hline Monte Aloia (co) & Tui & 610 & $27 / 10 / 1,70 / 14 \times 8,50$ & $75-100$ \\
\hline Vivero Forestal de Areas (co) & Tui & 70 & $7 / 1,5 / 0,42 / 5,5 \times 5,5$ & $5-10$ \\
\hline Vivero Forestal de Areas (co) & Tui & 70 & $6 / 1,75 / 0,35 / 6,5 \times 5,5$ & $5-10$ \\
\hline Pazo da Mercede (pu) & As Neves & 90 & $18,5 / 3,5 / 2,24 / 14 \times 12,5$ & $75-100$ \\
\hline
\end{tabular}

(co): haya común/( pe): haya péndula/( pu): haya purpúrea)/( tri): haya tricolor

Cuadro de datos geográficos y biométricos de hayas ornamentales memorables desaparecidas de Galicia (Rodríguez Dacal, en prensa)

\begin{tabular}{lllll}
\hline Localización & Municipio & Altitud (m) & Dendrometría (m) & Edad (años) \\
\hline Villa Eugenia $(\mathrm{pe})$ & Culleredo & $<50$ & $10 /--/ 1,50 / 369 \mathrm{~m}^{2}$ & $100-150$ \\
Pazo de San Lourenzo $(\mathrm{co})$ & Santiago & 230 & $21,5 / 6,5 / 3,25 / 19 \times 17$ & $100-125$ \\
Pazo de Torrecedeira $(\mathrm{pu})$ & Redondela & 120 & $32 /--/ 3,75 /--\mathrm{-}--$ & $125-150$ \\
Colegio Bella Vista $(\mathrm{co})$ & Vigo & $<50$ & $--/--/----\mathrm{-}--$ & $75-100$ \\
Pazo de Castrelos $(\mathrm{pu})$ & Vigo & 50 & $32 / 1,5 / 4,10 / 20 \times 20$ & $100-125$ \\
Pazo da Mercede $(\mathrm{pu})$ & As Neves & 90 & $30 / 4 / 3,90 / 23 \times 18$ & $100-125$
\end{tabular}

(co): haya común/( pe): haya péndula/( pu): haya purpúrea)/(tri): haya tricolor 